Portland State University

PDXScholar

1975

\title{
A Descriptive Study Regarding Perceptions of Sex Roles in Cooperative Households
}

\author{
Emily Fultz \\ Portland State University \\ Billie Huntwork \\ Portland State University
}

Follow this and additional works at: https://pdxscholar.library.pdx.edu/open_access_etds

Part of the Family, Life Course, and Society Commons, and the Gender and Sexuality Commons Let us know how access to this document benefits you.

\section{Recommended Citation}

Fultz, Emily and Huntwork, Billie, "A Descriptive Study Regarding Perceptions of Sex Roles in Cooperative Households" (1975). Dissertations and Theses. Paper 1879.

https://doi.org/10.15760/etd.1878

This Thesis is brought to you for free and open access. It has been accepted for inclusion in Dissertations and Theses by an authorized administrator of PDXScholar. Please contact us if we can make this document more accessible: pdxscholar@pdx.edu. 


\section{A DESCRIPTIVE STUDY REGARDING PERCEPTIONS OF SEX ROLES IN COOPERATIVE HOUSEHOLDS}

by

Emily Fultz

Billie Huntwork

A practicum submitted in partial fulfillment of the requirements for the degree of

MASTER OF SOCIAL WORK

Portland State Unlversity

1975 
Approved by Lewls $H$. Curtis,

Assoclate Professor of Soclal Work

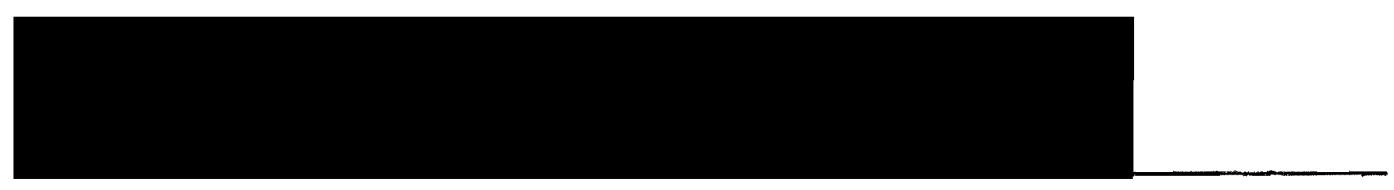


A CKNOW LEDGEMENTS

We wish to express our appreciation to those who made this study both possible and enjoyable. Our advisor, Lew Curtis, spent many long hours helping us through all phases of our research. His patience and good humor were greatly appreciated. Without the cooperation, friendliness and openness of restdents in the groups visited, this study would have been imposstble. Their warm responsiveness was a source of great pleasure. Appreciation is also expressed to Frank Miles, School of Soctal Work, for his ald in several technical a spects of the study. Our typist, Candy Genhelmer, combined competence and cheerfulness to make the final work of completing thịs study a pleasant task. Fellow students were also helpful in providing suggestions for groups to visit and content for investigation. Our respective households, who have now become "experts" on cooperative households, have sustained us w1th good-natured support and cooperation. 


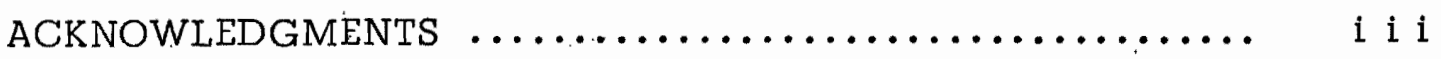

CHAPTER

I INTRODUCTION $\ldots \ldots \ldots \ldots \ldots \ldots \ldots \ldots \ldots \ldots \ldots$

I I REVIEW OF LITERATURE $\ldots \ldots \ldots \ldots \ldots \ldots \ldots \ldots \ldots$

I I I METHODOLOGY $\ldots \ldots \ldots \ldots \ldots \ldots \ldots \ldots \ldots \ldots \ldots \ldots \ldots$

I V FINDINGS $\ldots \ldots \ldots \ldots \ldots \ldots \ldots \ldots \ldots \ldots \ldots \ldots \ldots \ldots, 47$

$\mathrm{V}$ INTERPRETATION OF FINDINGS $\ldots \ldots \ldots \ldots \ldots \ldots \cdot 66$

V I DISCUSSION AND CONCLUSIONS $\ldots \ldots \ldots \ldots \ldots .76$

V I I EPILOGUE $\ldots \ldots \ldots \ldots \ldots \ldots \ldots \ldots \ldots \ldots \ldots \ldots \ldots \ldots$

BIBLIOGRAPHY $\ldots \ldots \ldots \ldots \ldots \ldots \ldots \ldots \ldots \ldots \ldots \ldots \ldots \ldots \ldots \ldots, 9 . \ldots \ldots$

APPENDIX

A COMMUNE/RESPONDENT INFORMATION

QUESTIONNAIRES - PRE-TEST ..............

B COMMUNE/RESPONDENT INFORMATION QUESTIONNAIRES .................... 115

C INTRODUCTION OF RESEARCH TO GROUPS ..... I31

D LIST Of VARIABLES $\ldots \ldots \ldots \ldots \ldots \ldots \ldots \ldots \ldots . .134$

E CODING CATEGORIES $\ldots \ldots \ldots \ldots \ldots \ldots \ldots \ldots . . \ldots \ldots$

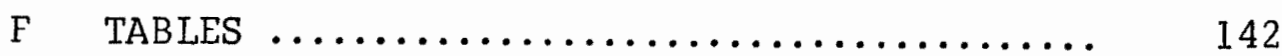

G DESCRIPTION OF GROUPS IN SAMPLE ........ 223

H FINAL LETTER TO SAMPLE GROUP $\ldots \ldots \ldots \ldots \ldots .245$ 


\section{CHAPTER I}

\section{INTRODUCTION}

The roles of men and women are among the many elements of contemporary American society which are in a process of rapid and sometimes disruptive change. The more or less traditional ways in which men and women have viewed themselves and each other are being openly challenged by a number of significant factors. Although there have always been those exceptional persons who questioned the inevitability of seemingly given role differentiation, today's soclal climate makes such questioning more common and acceptable.

A few specific factors may be mentioned as being of particular interest. With modern communication and mobility, the options for varled educational and employment opportunities and life styles avallable to both men and women have vastly increased. In a world threatened with overpopulation, there has appeared a marked decrease in family size expectations. Further, increasingly open challenges are being offered to the idea of the Inevitabillty and/or desirability of the nuclear family as the ideal life style for all persons.

The modern Women's Movement has spoken to all of the above issues and has added the unique dimension of heightened awareness of past and present role allocation for women and its associated critique of what society has apportioned to men as well. 


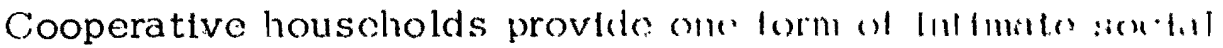

organization in which sex roles, in some form, will be expressed. It is the intent of this study to focus upon perceptions of sex roles within contemporary cooperative households. Generally, we wish to know whether or not certain group or individual factors are associated with the development of sex role patterns. If they are associated, in what ways? If they are associated, will this enable us to develop more focused questions which could be investigated in similar settings outside the population of this sample? Finally, we will examine whether our data and observations raise questions for further inquiry regarding sex role patterns within the nuclear family and/or society in general. As social workers we hope to gain some understanding of ways in which life in a cooperative household may provide one alternative among many for those seeking to develop roles which reflect their uniqueness as persons.

A brief note on terminology is required at this point to avoid confusion in the narrative to follow. We began our study using the designation "commune" for the groups we wished to include. However, a number of respondents in several different groups remarked on their dissatisfaction with this term. The basic reason for the concern expressed lies in the popular use of "commune" in ways which elicit a negative emotional response from persons in the larger society. Although recognizing that this response 
often reflects a lack of information and understanding, they still felt its use could detract from whatever helpful results might come from this study. With this in mind we have selected the term "cooperative household"l as an alternative and will use this phrase throughout most of the narrative and in the summary which will be returned to participants. However, in the Findings and Tables we will continue to use the word "commune" as these sections relate to data drawn directly from the questionnaires where this term is used. Our decision to use the broader term "cooperative household" is one way to emphasize the very great variety, uniqueness and flexibility we discovered in the course of this research. 
Footnotes for Chapter I

1. For a more precise working definition of this term, please refer to the chapter on Methodology, p.34-35. 
CHAPTER II

\section{REVIEW OF LITERATURE}

Introduction

In reviewing literature relevant to the topic of sex roles in cooperative settings, effort was made to move from a general framework of reference to a focus upon the specific issue under study. This approach involved first a consideration of general societal trends in American culture, with particular attention to the family and to changing sex role expectations. Literature dealing with cooperative living arrangements both in historical perspective and as existing today was reviewed to provide general background for the examination of sex roles in that type of setting. A small sample of literature was found dealing with specific aspects of sex roles in cooperative living situations.

General societal trends

Many authors have dealt with the phenomenon of rapid change in American culture. Philip Slaterl subtitles his Pursuit of Loneliness, "American Culture at the Breaking Point". He sees American society as ready for a major transition from an old culture based on scarcity, with an emphasis on competition, production and private property to a new culture based on abundance, emphasizing cooperation, distribution and community. 
Slater sees the new culture as one in which the values of equality, personal expression, and group sharing are primary. He sees such a climate as conduclve to communal living arrangements and to increased equality between men and women within these.

Several authors present critiques of society from the stance of the counterculture. In some cases they see the breakdown of old patterns as an opportunity for the incorporation of values and qualitles which in the past have been resisted or dismissed as youthful excesses. Yablonsky ${ }^{2}$ emphasized the need for American society to take seriously the emphasi s on compassion and love of the drop out or "hipple" movement. For him this does not mean wholehearted adoption of all the characteristics of any particular members of this group. However, he feels the presence of a few less widely acceptable attributes should not be made a stumbling block in the path of recognizing and appropriating genuinely valuable qualities. As Davis ${ }^{3}$ points out, these young persons may already be rehearsing new forms of cultural evolution which will deal with problems central to our future society. Among those he mentions are their resolution of the problems of compulsive consumption and passive spectatorship. The patterns which they have developed in response to these issues provide real options to the traps into which middle class Americans, in particular, are rapidly becoming entangled. Yablonsky 
draws a parellel between modern "hippies" and Christians in the Roman Empire, suggesting that tolerant understanding rather than persecution would be the more appropriate response, incorporating the values and persons of these groups into society to their mutual benefit.

Richard Flacks ${ }^{4}$, who has participated in the radical student movement, reflects upon it and upon the confusing and rapid change in the midst of which young adults must establish their identity. Family life has become less rigid, allowing youth to develop a sense of personal uniqueness and potential. At the same time he sees the incoherance resulting from a lack of standard, accepted mores as leaving the same youth without guidelines for the expression and development of those qualities. Youth are therefore unwilling to slip into old forms while at the same time being frustrated with the lack of change following their sacrifices and involvement. The student movement of the Sixties epitomizes this situation. Flacks suggests that only the formation of small parallel structures within society will enable disillusioned youth to continue in a meaningful challenge to established institutions. His premise is that by actualizing in microcosm the type of society they seek, they will gradually prepare more people to take power for themselves. In Flacks' view, this provides them with forms which may continue to be appropriate as they move into older age groups and 
also demonstrate a practiced alternative to the established system for that time when the larger society will either be willing to change or be forced to do so.

By way of introduction to a consideration of literature dealing with sex roles in American society, it may be useful to look briefly at Arlie Fussell Hochschild' $s^{5}$ evaluation of the field of sex role research. Hochschild states that "the issue of sex roles is the biggest blind spot in existing sociology" ( $\mathrm{p} .1023)$ In discussing the four types of research usually carried on she points out the underlying assumptions of each and most importantly the implicit models of inequality underlying the perspectives. Further points of significance are the blased use of language in descriptive studies and the obvious lack of attention to women of ethnic minorities and lower economic class. Although she recognizes the contributions of modern feminists, Hochschild sees the need for a major change in approach to the sociology of sex roles.

Keeping in mind the limitations suggested above, we may proceed to sketch an overview of sex role literature. Much of this literature is intimately tied to cultural understandings of family life. Assumptions regarding what is natural and good have tended in the past to relate closely to the roles of husband, wife, father, mother. Single adults, especially women, 
have tended to move into roles resembling those played out in the nuclear family. For many women, this has meant taking on tasks resembling the nurturing, conserving function, almost as if this were to be a direct substitute for literal mothering ${ }^{6}$ In order to understand the pervasiveness and power of society's role expectations, it is necessary to remember how early role training begins. Bardwick and Donvan ${ }^{7}$ describe in some detail the processes through which men and women develop their images of themselves and of each other. Perhaps it is this feeling of inevitability resulting from such socialization of men and women which makes such eminently rational proposals as Jessie Barnard's 8 "shared roles" and Olof Palme's ${ }^{9}$ description of Swedish objectives seem so very revolutionary on the emotional level. The basic idea in Bernard's article is that a truly equalitarian distribution of roles will never be possible until men and women share all roles. In a family setting this would mean that the male provider would be fully involved in child rearing and household functions and would also be relieved of part of his responsibility to give economic support. Practically speaking, this would involve part time jobs for both husband and wife and part time responsibility for home duties. Palme's article makes a similar suggestion. However, in his case what he describes represents official social policy, although as yet imperfectly implemented. 
He further emphasizes the loss of privilege to a man who has too little time to share in the care of his children, suggesting that especially when children are very young, fathers should be encouraged to cut back sufficiently to have meaningful responsibility and satisfaction in this area.

The vocal aspect of recent feminist literature leads one to forget how recent a phenomenon the insights represented in this literature are for the modern American woman. As recently as 1964 Alice Rossi 10 was making her "immodest proposal" for equallty between the sexes in a climate In which women were generally seen as satisfled or at least quiesent in their traditional roles and where full time motherhood was increasingly a reality, at least in the middle class. Although much current literature would reflect her underlying approach more widely, the practical considerations she raises of father involvement, of adequate day care and "practical mother" child care persons have still not been dealt with realistically by American society. Impatience with such slow progress in the implementation of equalitarian ideals may be seen to provide ample impetus for the seeking out of alternative forms of social organlzation to embody these new understandings. Historical and contemporary cooperative living

Background on utopian ideology

The idea of utopia seems always to have co-existed with humankind. Of the many philosophers, poets, polltical thinkers, artists and others who 
have considered and written of this Ideal, only a few can be mentioned here.

Buberll describes utopias as pictures of something not actually present, but only represented, of what "should be", what the visionary wishes to be. He sees the achievement of this absolute "rightness" as never possible for the individual alone, but only for the individual in human community. He goes on to say that such a picture is not in 1solation from the existing human condition, but is in relationship to the suffering and misery of humankind, standing over against it in contrast. He quotes Victor Hugo as calling utopia "the truth of tomorrow". That which today is seen an inopportune clears the way for a society to be. Another emphasis which Buber makes and which is pertinent to any consideration of practical communal experiments is that the essence of community is the presence of a "center". For Buber this involves a unifying philosophy, force or goal to which members are committed. Whether or not this center is recognized or acknowledged, he views it as that element with which all members have a common relationship. He uses the metaphor of the wheel to illustrate this idea, remarking that it is described by the radii, not by points on the circumference (p. 135). 
Tillach ${ }^{12}$ in Utoplas and Utopian Thought provides an excellent summary of some of the positive and negative characteristics of Utopia. The first positive aspect he mentions is the emphasis on the fulfullment of both the Individual and soclety. The personal and social elements cannot be separated without destroying the truth of the utopian Ideal. Tillach uses an illustration familiar to social workers of the lament of an analyst who seeks to deal with a person's private troubles without simultaneous attention to the public 1ssues present in the world to which the troubled person must return. He sees the utopian ldeal as one which tries to place a whole person in a whole environment. The second positive characteristic which Tillach identifies is the "fruitfullness" of utopia. By this he means the way in which this ideal opens up possibilities which might otherwise remain hidden to soclety. Power, the third positive quality, Tillach identifies as "the power of man in his wholeness" (p.299). This power is one which has been seen to transform reallty.

For each of these positive qualities Tillach then offers a corresponding negative element. In the case of the first he calls attention to the finiteness and estrangement of persons which is often forgotten by the utopian. He sees human existence as separating the person from his/her true and unattainable being. In place of fruitfullness Tillach sees the danger of wishful thinking, 
of the utopian deeming the impossible as possible. This tendency to unrealism has been the cause for the dissolution of many experiments in utopia. Where the two first negative aspects exist they lead naturally to the third, which Tillach sees as the powerlessness which grows out of disillusionment.

Tillach does not see the negative aspects of utopia as necessarily negating the posttive. When the element of transcendence is added it becomes possible to hold the pairs in balance and to make some moves forward. He describes transcendence as that quality of the living which always strives to move beyond itself. The element of risk, of reaching out which exists along with the natural motion for conservation places every utopla in a state of " hovering, a suspension, between possibility and impossibility" (p.302). Finally, Tillach declares the need of the utopian to recognize that the committment to be made is not to an absolute, but to an ambiguous beginning, to a reaching forward.

One author who has considered both ideological and practical questions of the utopian ideal is B.F. Skinner, 3 in his novel Walden Two. He describes the building of an ideal community through the use of behavioral engineering. He sees one generation as sufficient time to completely transform social priorities and to produce a group of happy, productive persons, without 
any of the weak and selfish characteristics of most societles.

Skinner, in his novel, was following in the tradition of such early utopians as Thomas More ${ }^{14}$ and Etienne Cabet ${ }^{15}$. However, he differs in that the process by which Walden Two was bullt uses those tools of behavioral science which are actually avallable. More and Cabet offered philosophical challenges to the evils of their times. Skinner's challenge was both philosophical and practical, even though he did not describe a community in actual existence. Other social idealists did seek to incarnate their utopian models, however. Among the best known are Charles Fourier ${ }^{16}$, and Robert Owen ${ }^{17}$. Fourier $(1772-1837)$ proposed a system of cooperative settlements based on production and called phalanxes. Among the communities based on his design were the North American Phalanx in New Jersey, phalanxes in Wisconsin and Iowa, and Brook Farm in the latter stages of its existence. None of these communities lasted very long and are seen by Kanter ${ }^{18}$ as among the unsuccessful of the nineteenth century. Robert Owen $(1771-1858)$ began as a mill owner in Wales. Out of his concern to avoid human subordination to machinery and other considerations, he eventually left manufacturing and turned to social criticism. His New Harmony community in Indlana is also seen as unsuccessful, however, his thought was undoubtedly influentlal, as was Fourier's in the development of new forms of social organization and protest. 
Brief notes on historical communities

There is a rich and varied literature dealing with American utoplan experiments, particularly of the nineteenth century. As early as 1875 Charles Nordhoff ${ }^{19}$ described The Communistic Societies of the United States. He provides a fascinating first hand glance into a number of the most interesting communities of the last century. Nordhoff 20 also provides excerpts from group literature and a good number of illustrations to give an added feeling for the life of the groups described.

Many of those who were active in the founding of utopian communities were prolific in their written expression of their ldeas and activities. John Humphrey Noyes 21 left assorted books and papers on the Oneida experiment. Adin Ballou ${ }^{22}$ left an account of the fortunes and misfortunes of the Hopedale Community.

A number of books have been written by persons who were related to early leaders of specific communities or who had personal contact as children. One of the most ambitious is a two volume work by Constance Noyes Robertson 23 , a granddaughter of John Humphrey Noyes, founder of the Oneida Community. She has drawn on a good deal of original material as well as her acquaintance with Oneida members to provide a thorough and sympathetic account of this group. John Humphrey Noyes' son, 
Pierrepoint Noyes ${ }^{24}$, also wrote an account of his early life in the community: Robert Dale Owen ${ }^{25}$, son of the founder of New Harmony, has described both his father and the efforts at community which he attempted .

In addition to those who enjoyed first or second hand experience with nineteenth century communities, a number of modern authors have made careful study of these groups. The one who has been most helpful to the authors of this study is Rosabeth Moss Kanter ${ }^{26}$. Her Committment and Community deals with an issue that is at the heart of the utopian ideal. Her analysis of the nature and process of committment as a key to an understanding of success in communal experiments provides excellent background for any consideration of long-term aspects of collective life. The bulk of her study focuses on characteristics of nineteenth century groups, but she also draws parallels with modern communities.

Raymond Muncy 27 is another scholar who has given attention to nineteenth century communities. His focus is on Sex and Marriage in Utopian Communities. He also draws on a wide variety of original and secondary sources for his description of sexual practices and relationships.

In the course of examining earlier utopian ideas and experiments, we gained perspective for our current study. The types of issues and character- 
istics described have provided ideas of factors to look for in modern communities. Specifically, insight has been gained in the ways women have been involved in such experiments and the impact on sex roles which has resulted.

\section{Modern communities}

As is true in the case of historical material, literature dealing with modern communal experiments ranges from the scholarly 28 to popular presentations of communal life in books, articles, and journals of personal experience. ${ }^{29}$

Numerous comparisons can be made between earlier communities and groups of more recent origin. The ideals which Richard Fairfield ${ }^{30}$ lists as being present in varying degrees among today's communards are echoes of those espoused by leaders of the past. 31

At the same time, Kanter comments, "The major difference between establishing a new community in the nineteenth and twentieth centuries is the degree of difficulty a group encounters in constructing strong boundaries and creating a coherent group". 32 Modern mobility, mass communication and rapid social change reduce the possibility of isolation and the expectations of relative permanence which were more characteristic of the nineteenth century. Additional internal strength is needed to maintain boundaries and 
:rosesion in the face of these pressures. Also, she sees the level of focus as having changed from attempts to create alternative societies to scaled-down efforts at alternative families.33 Other modern authors bear out this view in describing the smaller, more decentralized forms of community seen today 34 A few exceptions to this may be seen in the more formalized networks of religious communities. 35

Certain authors give special emphasis to the emergence of a communal life style as an intricate part of the phenomenon variously referred to as the counterculture, youth culture or hip culture..$^{36}$ They see the values emphasized by youth as finding a natural flowering in such arrangements, whether the focus be on personal develop ment removed from society or on personal sacrifice for societal change. While recognizing the unique climate of modern society, Odets ${ }^{37}$ also points out that communal emphases, a position readily supported by the historical material cited earlier, are not alien to American society. He expresses the idea that the dismissal of such groups as somehow outside the American tradition is an attempt by some in the larger society to deny their relevance and potential permanence.

Much of current literature points out the great variety and continuing change within the modern communal movement. Fairfield ${ }^{38}$ delineates seven general categories of communes in existence currently while Herbert Otto ${ }^{39}$ makes a distinction between sixteen varieties, although admitting to 
some overlap. One of the major dichotomies seen by many modern writers in that between the groups whose focus is on personal growth and fulfillment, usually with as little contact with the larger society as can be managed, and those communities who form with the express intent of working to change the larger society. While persons in the extreme camps see these two positions as irreconcilable 40 , others suggest that they are really complementary facets of the same overall struggle. 41 In the latter point of view, the more retreat oriented groups are seen as offering models toward which those who are actively seeking change can point. By living the kind of society for which others strive, they offer support to the cause of the socially and politically involved. At the same time they make oases of refreshment possible for persons immersed in social action, particularly in urban centers.

Considerable attention has been given to factors contributing to success and failure in the modern communal movement. First of all, even the use of those terms require explanation by anyone seeking to analyze group life. Some communards contend that longevity is no measure of success if those who have particlpated have grown and been able to move on to increasingly valid personal experiences. At the same time, there do seem to be some elements which effect how well a group is able to be that which it sets out to be. 
Some ${ }^{42}$ have remarked that the high emphasis given to openness and personal fulflliment has left some groups exploited to the point of near extinctIon by those who have taken without giving in return. The rapid movement in and out of groups which thls characteristic also fosters has also stood in the way of the development of a sense of "family" which has been a goal in formation. 43 Roberts ${ }^{44}$ maintains that group fallure or dissolution usually centers around one of four issues. These include lack of leadership, lack of means for handling internal disputes, lack of ideology and external repression. Kanter, Fairfield, and Melville 45 all mention lack of leadership as a common source of difficulty. Kanter's studies have emphasized the role of committment and the need for some sense of a purpose or goal outside of the Individual. Patrick Conover ${ }^{46}$ suggests a relaxed and responsible approach to the questions around communal success. He emphasizes realistlc values and a sense of responsibility among those who would live closely together. Perhaps his down-to-earth but optimistic approach would be an appropriate standard for those desiring to enter a truly cooperative life together. $\underline{\text { Sex roles in cooperative households }}$

Most discussion of sex roles in cooperative households falls into four overall areas of concern. Consciousness of sexual identity, emotional roles, practlcal division of labor and child rearlng may be used as terms to describe these four foci. 
In the first area, that of sexual Identity, a number of authors write of the increased awareness which comes to communards of their own maleness and femaleness. At the same time they become more sensitive to the ways in whtch they have been soclalized into narrow roles within each sex. Women from several communes in discussing their experlences point out that for the first time they have the space and time to deal with sexism. ${ }^{4}$ They also credit the atmosphere of trust and mutual caring common to such an arrangement with making possible understanding and respect for others' feelings about themselves as men and women. Kanter ${ }^{48}$ points out that In communal living women are not defined by their marital status as is the case in the larger society. They are therefore free to define themselves on their own terms, apart from men. The natural corollary is that men are also released from their constricted roles in relation to women and chlldren. The practical outcome of such increased consciousness is seen in the other three areas of concern.

Although it is more difficult to achieve and harder to measure, as described in current literature, emotional growth and equality are major goals of persons living in cooperative households. Both men and women seek an atmosphere in which they may express emotional qualities usually considered to be exclusive to one or to the other. Marnie Oats of Twin Oaks focuses on 
what is probably the key to achleving progress in this area when she defines the group goal "to be nonagressive, noncompetetive, and nonexploitive ${ }^{49}$. As Oats goes on to point out, in this setting men and women can serve as models for one another, both in the expression of emotional qualities which each possesses and in the practical learning of new skills and behaviors. One summary of this issue may be seen in an excerpt from the statement of purpose of a group visited by the authors.

"We live in a community as men and women because we appreciate that the diverse gifts of vision, wisdom, and beauty given to each sex offer fuller dimension to our humanness. We complement each other, we learn from each other and in our differences there is strength."

While thls statement may imply distinction between the sexes, the actual emphasts is more upon the completeness they each find as they learn human qualities from persons of the opposite sex.

Probably the most discussion centers around the practical implications of desired equalitarian goals. This is sue is not as new a concern as might be imagined. "When the partition between the sexes is taken away, when man ceases to make woman a propogative drudge, when love takes the place of shame, men and women will be able to mingle in all their employments ." 50 These words, a century old, describe the philosophy of the Oneida Community In this group men and women shared work, responsibllity and decision making. Even such social restrictions as dress style were cast aside to allow women 
fuller personal expression..$^{51}$ Within the nineteenth century utopian communities there was much variety in the amount of freedom and equallty avallable to women. Even in a few situations where some practical tasks were shared, power was not always simllarly shared. Nordhoff $5^{2}$ describes In some detail the life styles of a number of communities. He notes that in Amana both boys and girls were required to learn knitting, but at the same time all leadership was male and only máles could vote. Attitudes toward physical sexual activity were not always a measure of women's status in a group. Both celibacy and free love as practiced in different communities resulted in varied levels of freedom and equality for women members. Nordhoff also describes Shaker society which was celibate but where women had major leadership roles from the time of Ann Lee on. Muncy $y^{53}$ also points out the great diversity present in relation to rights of women. He mentions the Mormons as one group in which no pretense at equality is made, women belng seen as totally in subjection to men in all areas. Muncy's treatment of this subject is somewhat more sceptical than some, his view being that the supposed equality of some communities leads to uncertainty and frustration for many women unused to this ideal. Although there have always been strong feminists (sometimes both female and male) in American society, they represented a very limited force in nineteenth century utoplan communities . 
The impact which they had was therefore quite different from what is possible in today's society, as will be seen as we briefly examine literature related to task distribution in modern communities .

Articles and studies dealing with task distribution in modern cooperative households indicate a widespread.will on the part of both men and women to engage in tasks which have previously been designated as sex related. This will, however, is not always sufficient to overcome years of conditioning and practical pressures both from inside and outside the household. Kanter and Halter's ${ }^{54}$ excellent paper on changing sex roles in urban communes summarizes much that is to be found in other sources. They comment on the new emphasis on the value of nurturant activities and tasks related to the maintenance of environment. Ecological awareness emphasizes humankind's dependence upon the natural world and the responsibility all have in using its gifts and.caring for its resources. The ritual qualities of preparing food and eating are being revived in some present day households. Similar emphasis can be seen in descriptions of " back to the land "groups. In spite of this view, others mention the lack of value placed on traditional women's work. In an informal conference of women from a number of communities, ${ }^{55}$ participants discussed the special problems of women who are anxious to learn male tasks but fear they will not come up 
to standard. On the other hand, women's work is seen as something that anyone can do, as lacking any need for expertise and therefore any value. They raise the question of whether such work is intrinsically of less value or whether this has been arbitrarily determined by society. They further point out the difference in the level of self confidence between men and women as each sets out to learn the tasks of the other. They see their greater lack of confidence as a major impediment. Minturn 56 in a somewhat nondefined, informal study, focuses her attention on the noncompetitive nature of communal living as compared to that of the larger society. She finds that commune members do more cross sex chores than her sample of students and also that men do more of this than women. She finds some connection between the breakup of communes and the exploitation of women. Overall she indicates that the noncompetitive nature of commune life allows for much more flexible work patterns and self perceptions.

Closely related to the issue of task allocation, but somewhat unique, is the area of child-rearing. Several authors indicate this to be a central testing point for the ideals and styles of communal groups. Kanter and Halter 57 point out that this is the one area where significant difficulty exists, even in those groups which have been able to deal with almost all other male-female issues. Twin Oaks in Virginia, modeled after Skinner's Walden Two, is one. 
community which has taken a. long-range, problem solving approach to this matter. Early experience with children as described by Kincade 58 demonstrated the unreadiness of Twin Oaks to engage in a truly equalitarian program of child-rearing. She lists four elements which contributed to conflict and lack of success. These factors are parent worries, parental jealousy, community theory and community inexperience. In the face of these difficulties the members of Twin Oaks set out to prepare themselves for the task of incorporating children. Within a two year period they had developed a plan, begun work on a children's house and generally laid the groundwork for including children. A follow-up article in Communities magazine ${ }^{59}$ indicates that this preparation yielded valuable results. Three children had been born at that point, with another expected shortly. Eight " metas " ( p.11) had been chosen, men and women, biological parents and non-parents. In addition to this responsible group, all community members are free to spend time with the children. Biological parents have no special privileges over other members, except for the nursing mother's particular task. Communities in which such careful planning has not taken place show very different results. In several of the very flexible groups described 60 a special problem exists where fathers move in and out of relationship with the mothers of their children. Numerous examples are given where fathers just take off, 
leaving the women to support and care for their children alone or with such other help as the community members are ready to give. If the experience of Twin Oaks, the Israeli kibbutzim ${ }^{61}$ and other fairly structured communities is representative, it would appear that there is considerable risk in attempting to incorporate children into cooperative households where provision for stable and long term responsibility is not built into community organization. All the evidence of the hip communes of rural areas and such urban experiments as described by Weiss and Kanter and Halter 62 point to major difficulty in sharing child rearing under more fluid conditions. 
Footnotes for Chapter II

1. Philip Slater, The Pursuit of Loneliness, Boston, Beacon Pross, 1970.

2. Lewis Yablonsky, The Hippie Trip, New York, Bobbs - Merrill Co., Inc., 1968 esp. Chapter 15.

3. Fred Davis, "Why All of Us May Be Hippies One Day", Trans-action, vol. 5, no. 2, December, 1967.

4. Richard Flacks, Youth and Social Change, Chicago, Markham Pub. Co., 1971, esp. Chapters 2 and 5. Flack's position is succinctly summarized in "Intelligencia in Revolt", Trans-action, vol. 7, no. 8, January, 1970, pp. $46-55$.

5. Arlie Russell Hochschild, "A Review of Sex Role Research", American Journal of Sociology, vol. 78, no. 4, January, 1972, pp. 1,011-1,029.

6. Margaret Adams, "The Compassion Trap", Women in Sexist Society, ed. by Vivian Gernick and Barbara K. Moran, New York, Basic Books, 1971, pp. $555-575$.

7. Judith M. Bardwick and Elizabeth Donvan, "Ambivalence: The Socialization of Women", ibid., pp. 225 - 239. See also Mirra Komarovsky, "Learning the Feminine Role", The Family and the Sexual Revolution, ed. by Edwin M. Schur, Bloomington, Indiana University Press, 1964, pp. 213 223.

8. Jessie Barnard, "Changing Family Life Styles: One Role, Two Roles, Shared Roles", The Future of the Family, ed. by Louise Kapp Howe, New York, Simon and Schuster, 1972, pp. $235-246$.

9. Olof Palme, "Lesson from Sweden: The Emancipation of Man", ibid. , pp. 247 258.

10. Alice Rossi, "Equality of the Sexes: An Immodest Proposal", The Woman in America, ed. by Robert Jay Lifton, Boston, Houghton Mifflin Co., 1965, pp. $98-143$.

11. Martin Buber, Paths in Utopia, Boston, Beacon Press, 1949, pp. 7 - 15, $129-138$. 
Footnotes for Chapter II ( continued)

12. Paul Tillach, "Critique and Justifications of Utopias", Utopias and Utopian Thought, ed. by Frank Manuel, Boston, Houghton Mifflin Co., 1966, pp. $296-309$.

13. B.F..Skinner, Walden Two, New York, MacMillan, 1948 .

14. Moritz Kaufman, Utopias; or Schemes of Social Improvement, London, C. Kegan Paul and Co., 1879, pp. 1-13.

15. Ibid, pp. $123-142$.

16. Charles Fourier, Encyclopedia Britannica, 15th. edition, vol. IV, pp. $254-255$.

17. Robert Owen, ibid., vol. VII, p.643.

18. Rosabeth Moss Kanter, Commitment and Community, Cambridge, Massachusetts, Harvard University Press, 1972, pp. $247-248$.

19. Charles Nordhoff, The Communistic Societies of the United States, New York, Hillary House Pub. Itd., 1960 (originally published 1875).

20. Ibid, pp. $81-84,170-179,266-268$ a

21. John Humphrey Noyes, History of American Socialisms, New York, Hillory House, 1961 (originally published 1870).

22. Adin Ballou, History of the Hopedale Community, ed. by W.S. Hey wood, Philadelphia, Porcupine Press, 1972 (Reprint of 1897 edition).

23. Constance Noyes Robertson, Onedia Community: An Autobiography, $1851-1876$, Syracuse, New York, Syracuse University Press, 1970 and Oneida Community: The Breakup, $1876-1881$, Syracuse University Press, 1972 .

24. Pierrepont Noyes, My Father's House: An Oneida Boyhood, New York, Farrar and Rinehart, 1937 .

25. Robert Dale Owen, The Life of Robert Owen, By Himself, London, G. Bell, 1920 . 
Footnotes for Chapter II

(continued )

26. Kanter, op.cit.

27. Raymond Lee Muncy, Sex and Marriage in Utopian Communities, Baltimore, Penguin Books, 1974 .

28. Kanter, op. cit.; pp. 163 - 237; Benjamin Zablocki, The Joyful

Community , Baltimore, Penguin Books, 1971 .

29. Stephen Diamond, What the Trees Said, Life on a New Age Farm, New York, Dell Pub. Co., 1971; Robert Houriet, Getting Back Together, New York, Coward, McMann and Geoghegan, Inc., 1971; Weiss, Living Together: A Year in the Life of a City Commune, New York, McGraw Hill, 1974.

30. Richard Fairfield, Communes, USA, Baltimore, Maryland, Penguin Books, 1972,. pp. 361-367.

31. Nordhoff, op. cit., pp. $399-418$.

32. Kanter, op. cit., p. 169 .

33. Ibid., p. 166 .

34. Houriet, op. cit.; Richard Fairfield, ed., Utopia, USA, San Francisco, Alternatives Foundation, 1972 .

35. Fairfield, ed, Utopia USA, pp. $57-60,66-73$; Kanter, op. cit. p.227; Mary White Harder et al, "Jesus People", Psychology Today, vol. 6, no. 7, December, 1972 , pp. $45-50,110-113$.

36. Keith Melville, Communes in the Counter Culture, New York, William Morrow and Co., Inc. 1972; Fairfield, Communes, USA; Flacks, Youth and Social Change ,Yablonsky, op.cit.

37. Fairfield, Utopia, USA, pp. $3-4$.

38. Fairfield, Communes, USA, p.2 
Footnotes for Chapter II ( continued)

39. Fairfield, Utopia USA, pp. $9-13$.

40. Ibid-, pp. $132-133$.

41. Movement for a New Society, "New Society Packet", available from The Movement - Building Collective, 4722 Baltimore Ave. Philadelphia, Pennsylvania 19143 [n.d.]; Fairfield, Utopia USA, pp. $102-105$.

42. Houriet, op. cit., pp. $131-187$; Yablonsky, op. cit.

43. Rosabeth Moss Kanter, ed. Communes, Creating and Managing the Collective Life, New York, Harper and Row , 1973, p. 400 .

44. Ron E. Roberts, The New'Communes, Englewood-Cliffs, New Jersey, Prentice - Hall, Inc. , 1971 .

45. Kanter, Commitment and Community; Fairfield, Communes, USA ; Melville, op. cit .

46. Fairfield, Utopia USA, pp. $227-229$.

47. "Some Views from Women in Communes", Communities, no. 7 , March - April, 1974, pp. $11-13$.

48. Kanter, Communes, Creating and Managing the Collective Life, p. 300 .

49. Marnie Oats, "Twin Oaks", Women: A Journal of Liberation, vol. 2, no. 4,1972, pp. $28-30$.

50. John Humphrey Noyes, quoted in Rosabeth Moss Kanter, "Communes for All Reasons", MS, vol. 3, no. 2, August, 1974, p. 62 .

51. Ibid.

52. Nordhoff, op.cit.

53. Muncy, op.cit. 
Footnotes for Chapter II ( continued)

54. Rosabeth Moss Kanter and Marilyn Halter, "De - housewiving Women, Domesticating Men: Changing Sex Roles in Urban Communes", Unpublished paper presented at the American Psychological Association, Montreal, August, 1973.

55. "Women in Community", Communities, no. 8, May - June, 1974, pp. $2-6$.

56. Leigh Minturn, "Sex Role Differentiation in Contemporary Communes", Unpublished paper.

57. Kanter and Halter, op. cit.

58. Kathleen Kincade, "A Walden Two Experiment", Psychology Today, vol. 6, no. 9, February, 1973, pp. $71-82$.

59. "Twin Oaks and Little Folks", Communities, no. 9, July - August, 1974, pp. $10-12$.

60. Houriet, op. cit.

61. Bruno Bettelheim, Children of the Dream, New York, Avon Books, 1969.

62. Weiss, op. cit. and Kanter and Halter, op. cit. 
CHAPTER I I I

METHODOLOGY

Because of the exploratory nature of this study, it was the intent of the authors to begin with a very general statement of the focus of our attention, accompanied by a list of variables which were seen as potential sources of data. Knowing the limitation of time which would require us to narrow our study even further, we selected a number of specific areas from which to draw tentative guiding hypotheses for more detailed examination. Specific suggestions for future study were seen as a goal for the conclusion of this preliminary research.

Statement of general focus of study

As noted in the Introduction, the general focus of this study is on perceptions of sex roles in contemporary cooperative households. In order to gather data related to questions derived from this focus, a survey instrument was constructed around a wide range of variables. These variables as related both to individual respondents and cooperative households are included in Appendix D.

Tentạtive guiding hypotheses

The tentative guiding hypotheses which follow are those upon which we will concentrate our attention. 
1. There is a difference in how men and women report levels of satisfaction with decisions (if there were decisions) or with development of sex roles (if there were no decisions).

2. There is a difference in how men and women perceive task division ( household by household).

3. There is a difference in how men and women report perceptions of whether sex roles were discussed at formation.

4. There is a difference between rural and urban cooperative households in perceived task division (divided by sex).

5. There is a difference between rural and urban cooperative households in new activities undertaken by members since joining (divided by sex).

6. There is a difference between rural and urban cooperative households in members' satisfaction level (divided by sex).

7. Satisfaction level is associated with frequency of discussion of similar issues (divided by sex) .

8. Satisfaction level is associated with perceived task division (divided by sex).

Sample

In order to make a selection of groups to be included in the sample, it was necessary to clarify what we considered a cooperative household to be. Our definition is quite broad; however, this can be justified by the nature of our study. Our intent was descriptive and exploratory only, with no expectation that we would be able to generalize beyond the actual sample population. Any more focused issues which might emerge at the completion of the research will be presented as questions for future study, where a more precise definition and more scientifically drawn sample might be required. 
We thus defined cooperative household as a group of people voluntarily living together in an intentional community. Such a community can be identified as an entity with both physical and social boundaries . It must include persons not related by kinship, who share resources and responsibilities and are bound together by common values and interpersonal commitment. It must also include more than three adults. This definition includes groups who refer to themselves as extended families, collective households, living collectives, communes, intentional communities or just people living together.

It was impossible to draw a random sample because an inclusive list of such groups does not exist. It was also unnecessary since we were not purporting to be able to generalize from our data. We therefore set out to draw a purposive and accessible sample.

We decided to include both urban and rural groups of as varied a nature as possible; groups with families, singles, married couples without children, and combinations; political and nonpolitical; and religious and nonreligious groups. We hoped that such a varied sample would provide enough differences so that comparisons could then be made.

Within this framework, geographical accessibility, willingness to participate, and our knowledge of the groups' existence determined our sample. We began by asking friends, fellow students and professors. As we began 
visiting groups, they often told us of others. Listings of communal groups in Communities magazine and Open Northwest Network also guided us to a few groups. One group was found through an ad we placed in the Scribe, a Portland alternative newspaper. Before deciding to include each group we mea sured them by our definition.

Most groups we heard about and contacted agreed to participate. Some were initially reached by phone, some in person, and some by letter. ${ }^{1}$ All were told of the nature of the study before deciding to participate. In many cases the group was allowed to examine the questionna ire before their decision. One group declined, saying they had become a private family and were not open to visitors and researchers. A few groups simply did not respond to our request even after follow-up phone calls or letters. Generally though, we encountered less difficulty in drawing a sample than we had originally anticipated.

Within each group we visited, availability and willingness to participate determined who actually served as respondents. We reached $100 \%$ in some groups, down to as. low as $43 \%$ in one group. Although $100 \%$ in every group would have been desirable, it seemed counterproductive to push participation too strongly. Also, in a number of groups, several visits would have been required to catch everyone at home, which was not possible. 
Our final sample included nineteen groups, eighteen scattered throughout the Pacific Northwest and one in the midwest. The total number of respondents was ninety-four. Research instrument

The research instrument was designed to provide specific data related to the focus of the study, while being flexible enough to allow respondents to expand in areas of particular interest to them. We recognized that this flexibility would undoubtedly result in much data which would be difficult to code and interpret. However, we felt that a more restricted approach would tend to force respondents into answers which might be an inadequate expression of their perceptions and feelings, thereby causing us to miss information which might be of genuine value.

The process of construction of the final questionnaire covered a number of steps.

1. We examined material in certain relevant literature. The interview schedule used by Kanter 2 was especially helpful. We also looked at scales related to the mea surement of attitudes. 3 These latter were for the purpose of gaining general ideas and were not incorporated into our design.

2. We delineated certain base information about cooperative households as groups and about individual respondents. Effort was made to eliminate material which could not be seen as of possible relevance to the major topic. 
3. Consultation with advisors and informal conversation with persons involved in or familiar with such living arrangements were used to check out perceptions of what might be most helpfully included.

4. Questions were formulated out of the above steps. This resulted in a pretest instrument of two parts. (see Appendix A) One, focusing on information relative to the group as a whole, consisted of thirty-four questions. These were to be answered by one person familiar with the group's history, allowing for cross checking by other persons. This cross checking was expected to be of an informal nature, generally in a group setting. Both factual questions and questions dealing with perceptions were included. The second questionnaire was prepared for individual members of each group to answer. It consisted of thirty-three questions covering both personal identifying facts (exclusive of name), questions related to household formation and participation, and those specific to sex role development. Both structured and open-ended questions were used. They were designed to elicit information and response on three levels.

a. the person's ideals and expectations

b. actual perceived experience in the group

c. feelings about how roles had developed or were developing

5. For administration of the pretest, we selected one rural and one urban cooperative household which had indicated willingness to participate in the study. We explained to each that this was a pretest questionnaire and would therefore be somewhat more timeconsuming than we expected the final instrument to be. We requested feedback on both the content and administration of the questionnaire. Both of us were present for each interview. We began the first interview prepared to adapt our procedures on the basis of members' responses. The pretest questions were designed as a standard interview schedule with the researchers asking questions and writing down responses. After a very brief beginning in this way (about $11 / 2$ questionnaires), both of us felt this was just too stilted and pretentious a technique and would further require much too long a time to be practicable. Therefore, after sharing 


\section{5. ( continued)}

with the group some of our feelings of discomfort and receiving support from those present, we switched immediately to allowing individuals to fill out their own questionnaires while we participated in one or more of the following ways:

a. clarifying questions, without offering any indication as to optional answers or giving examples,

b. listening to discussion between respondents over questions, and taking inconspicuous notes on these,

c. pursuing related issues and feelings as these were expressed by respondents.

For the second group we explained our change of idea as to procedure and all responded positively to the choice of writing their own answers, again with time allowed for clarification and discussion.

6. The final questionnaire incorporated changes resulting from pretest experience. The questions were reorganized with improved sequences and more of an outline form. Questions relating to children were placed together to allow groups without children to omit them when appropriate. Race and religion were removed. Race had been seen as a researcher observation not to read to the respondent and therefore became inappropriate for a questionnaire to be filled out in person. Religion raised many questions and it appeared that religious elements would be covered by other questions where they were at all pertinent. Marital status was removed from the respondent questionnaire to be replaced by a more broadly defined category.

The final instrument consisted of twenty-seven questions related to information from the group and thirty respondent questions (see appendix B). Data collection

The cooperative households in our sample were visited between May 31 and November 4,1974 . In fifteen of the groups both authors were present for the administration of the questionnaire, in three cases one was present and in 
one group with a very difficult schedule questionnaires were left and picked up after all had finished. Appointments were set usually a week or two before our visit. The length of time spent with each group varied from two and a half hours to an entire day depending on one or several of the following factors: 1) how quickly the group got together (in rural groups, especially, there was a lot of coming and going because of chores), 2) how much discussion occured during and after filling out the questionnaires, 3) how much time was spent touring property, 4) how long individuals took to complete the questionnaires, and 5) how much time we had available. We did not press for any particular time limit, as our method was to adapt to the mood and situation of each group.

Data collected from each group included a commune information questionnaire filled out by one or two persons with consultation from the group, individual respondent questionnaires completed by all those who were available and willing and observations made by us on the basis of discussions between group members and tours of the property where appropriate.

Our method of administering the questionnaire was first to explain our rationale for doing this study. We explained that we were graduate social work students who chose this topic because we believe that social workers need to know more about alternative life styles in order to be most helpful to people who may be dissatisfied and searching. We further explained that we originally 
wanted to study cooperative households as an alternative to the nuclear family but found this too broad and unmanageable. Then we continued to relate that we narrowed our study to sex roles as this is a topic of current interest and we were interested in seeing what is actually happening in this aspect of shared living. We acknowledged that we will not be able to make any generalizations to other similar groups and that our research is primarily exploratory. We reiterated the confidential nature of all responses. After this introduction, we asked individuals if they wished to participate. If they did wish to, we handed them a questionnaire, let them know we were available for clarification and questions and suggested that they read the questionnaire carefully, as there were some questions they would not need to answer. When questions did arise, we attempted to clarify without offering any indication as to possible answers. Questionnaires were usually filled out in one room but occasionally a person would retire to another area with the questionnaire. As individuals finished we expressed our appreciation for their help. We also left copies for persons not available at the time but whom group members seemed to think would be interested. Self-addressed, stamped envelopes were also left, but very few (3) of these were returned. As will be noted in the Descriptions of Groups in Sample (see appendix G) group number seven did not formally answer the questionnaires. Respondent information from this group is not included as data in the Findings but is used only for general discussion. 
Observations which we made were based on previously determined categories. These categories included impressions of the physical setting, tenor of group relationships, their response to us and the questionnaire and whatever else seemed interesting and pertinent. Group members offered many, many comments that would fall into the last category.

We attempted to avoid biasing factors as much as possible, but nevertheless, many such may have been present. The fact of two women doing the research may have raised questions regarding our stance on sex roles. Also, just the choice of sex roles perhaps alerted respondents that we might have had opinions in that area. We did observe some joking among respondents regarding "how well" they would do. Also, several explanations were offered, some defensive, of why groups often were not able to reach their ideals in terms of the roles of men and women. Our response in such instances was toremark that we did not have a set idea of how things "should be" but wanted to discover what was actually happening.

Another possible biasing factor is that respondents were often curious about other members' answers or could not remember certain background details. In such cases a discussion would often ensue. We attempted to keep this to a minimum and encourage respondents to relate their own ideas and feelings on the questionnaire. However, we did not entirely block these discussions. For one thing, it would have been impossible to do so. Furthermore, we felt it 
would have been counterproductive because these brief discussions seemed to increase interest in the questionnaire and to encourage real examination of thoughts and feelings. It was our feeling that these discussions resulted in no significant change of answers.

Our observations in the category or "whatever seemed pertinent or interesting" were probably biased by discussions with the groups and individuals subsequent to completion of the questionnaires. For example, at that point we allowed ourselves to relate our own views and general impressions of what other groups were doing. It should be noted in this regard that care was taken to deal only in generalizations to avoid identification of any other group visited. This more open discussion may have influenced the quality and quantity of their responses and thus influenced our observations. Whenever these types of observations are related, this possible bias should be taken into consideration.

Subsequent to each visit a thank you letter was sent to each group. Also, all were promised feedback in the form of a summary of our findings and conclusions (see appendix H). Many groups requested this and others responded positively when it was offered.

Coding

Before we began administering the questionnaire we prepared a list of coding categories into which we hoped to be able to place all responses. 
The major problem experienced in this process was establishing precisely what would be included in each category. Although we are generally satisfied with the results, we would have preferred terminology which would have been more obviously self-explanatory. We recognize that the nature of the questions asked elicited data which could not be easily and exclusively coded.

The original coding categories for responses to each of the open-ended questions are included in Appendix E.

During the course of collecting data we perceived that a number of changes would be necessary in order to reflect responses more adequately and also to avoid an unwieldy number of "other" items, where obvious new categories would be appropriate.

We therefore made the coding changes and clarifications listed in Appendix E.

The coding process consisted of both authors coding every response separately, either directly from the questionnaires or from cards onto which the answers had been copied. The coding was then compared and where there were differences of opinion these were negotiated until consensus was reached. Generally, both authors feel comfortable with this process and with the resultant classification. Most disagreements came more from individual interpretation of the limits of a particular category than from difference in perception related to the responses. Changes made were divided fairly evenly between the two 
authors. On occasion simple errors of reading or mixing questions were responsible for differences. In these cases our mutual checking identified and corrected such lapses. 
Footnotes for Chapter III

1. A summary of information used in initial contacts is included in Appendix $\mathrm{C}$.

2. Rosabeth Moss Kanter, Commitment and Community, pp. $251-269$.

3. Delbert C. Miller, Handbook of Research Design and Social Measurement, 2nd. ed., New York, McKay, 1970; Marvin E. Shaw and J. M. Wright, Scales for the Measurement of Attitudes, New York, McGraw-Hill, 1967. 


\section{CHAPTER IV \\ FINDINGS}

A summary of data obtained from the questionna ires is included

in this section. This data will be considered in three parts, one for

each of the questionnaires and one for data specific to our guiding hypotheses. Commune information

Data obtained from the "Commune Information" questionnaire is contained in Tables $1-40$ in Appendix F. Most of the tables are self-explanatory. The group questions provide general background information against which to view individual perceptions and feelings regarding sex role development in the respective groups. A few comments are appropriate to call attention to particular data.

Table 1, dealing with the life span of each group indicates $77 \%$ of urban and $50 \%$ of rural groups in the sample have been in existence between one and three years. Only two urban and no rural groups were of more recent origin. Of those over three years in duration, three ( $50 \%)$ of the rural groups were included and only one ( $8 \%$ ) of the urban groups. As will be noted in Table 2 all groups have been in continuous existence since their formation. Membership has fluctuated somewhat in several groups as will be observed in Tables $3-7$. However, Table 4 indicates that no urban group has lost more than six persons and only two rural groups have lost more than six persons. 
Groups with a large number of new members (Table 5 ) are also few, with only one urban and two rural groups reporting more than six new members since formation. In terms of current membership $85 \%$ of urban and $100 \%$ of rural groups report four or more members as having been residents for more than six: months (Table 6 ).

Tables 10 and 11 show the number of children resident in the groups. Only five urban groups ( $38 \%$ ) had children under 14 and no urban group had older children. In terms of actual numbers this represents nine younger children in urban groups and 12 younger and 2 older children in rural groups. Because of the very small total of children in the sample, the questionnaire data related to them has not been included in the findings.

Nine urban (69\%) and two rural ( $331 / 3 \%)$ groups report two to four members in ongoing couple relationships. Six urban (46\%) and two rural $(331 / 3 \%)$ report two to four members legally married.

Among the groups in this sample most were separate entities rather than being part of any 1 arger network. Table 15 shows $77 \%$ urban and $83 \%$ rural to be separate entites .

Table 16 indicates considerable divergence between urban and rural groups in relation to criteria for membership. Over half (62\%) of the urban groups listed similar values as of highest priority whereas $50 \%$ of rural groups listed personal interest in joining as of primary importance. It should be 
noted, however, that these categories are not mutually exclusive as many groups offered multiple criteria as important. Table 17 indicates more rural ( $83 \%$ ) than urban (62\%) groups interested in new members. In Table 18 availability of space is seen as the major factor ( $54 \%$ ) affecting urban groups'acceptance of new members. This factor was of significance for only one rural group $(17 \%)$. On the other hand two rural groups ( $331 / 3 \%)$ listed usefulness to the group as the primary factor.

Tables 19 and 20 show one of the major differences between urban and rural groups. In all cases where response was made, all urban members live together in a single house and all rural members have separate dwelling spaces. This difference disappears when facilities for general use are examined in Table 21. An overwhelming majority of both urban ( $85 \%$ to $100 \%$ ) and rural ( $83 \%$ to $100 \%$ ) groups indicate that group facilities are generally communal for all.

Ownership of property also varies between urban and rural groups . Only $38 \%$ of urban groups own property whereas $100 \%$ of the rural groups do. (Table 24) No single factor seems to predominate for either urban or rural groups in relation to how property was obtained (Table 25), how it is held (Table 26), or how it would be disposed of if the group were to disband ( Table 27 ). Although Table 24 indicated that only $38 \%$ of urban groups currently own property, it will be noted in Table 28 that an equal number 
( $38 \%)$ plan to do so if possible.

Contributions for group support vary somewhat between urban and rural groups. Table 29 shows $62 \%$ of urban and $331 / 3 \%$ of rural groups being supported by equal contributions from all, whereas only $15 \%$ of urban and $331 / 3 \%$ of rural groups base contributions on members' ability to pay . Although the above indicates that more urban than rural members pay equal shares, Table 30 indicates that slightly more urban ( $31 \%)$ than rural $(17 \%)$ may be exempted from financial contributions. Most ( $23 \%)$ of these would appear to be for service outside the group (Table 31 ). When sources of income are reported, Table 32 would appear to indicate that paid jobs in the outside community provide the largest source of such income for both men and women in both urban and rural groups.

The final section of the group questionnaire dealt with group meetings . Although no clear overall pattern emerged in this data, some trends may be noted. Table 36 shows that $38 \%$ of urban and $17 \%$ of rural groups held meetings weekly, the most frequent choice. Expectations for member attendance at such meetings was high in both groups ( $85 \%$ urban and $67 \%$ rural) as shown in Table 37. Where frequency of meetings has changed over time, the general tendency has been to become less frequent ( $31 \%$ urban and $67 \%$ rural ) as Table 38 indicates. No clear information is gained in Tables 39 and 40 to explain these changes, although in explaining decrease in frequency in rural 
groups $331 / 3 \%$ replied that things got organized and the same number of rural groups said that meetings were negative (Table 39 ).

Respondent information

Tables 41 - 82 contain data obtained from the "Respondent Information" questionnaire. Many of these tables, located in Appendix F, are also self-explanatory.

\section{Rase information}

Tables 41 and 42 show the sample as fairly evenly divided between men and women ( $51 \%$ male, $49 \%$ female) and concentrated in age between twenty-one and thirty years. $77 \%$ of men and $76 \%$ of women are in this range.

Table 45 shows a slightly higher percentage of men $(60 \%)$ than women ( $54 \%$ ) to be in ongoing couple relationships. $52 \%$ of men and $46 \%$ of women have partners who are also resident in their group.

Educational level attained is fairly even between men and women and concentrated in the range of some college to college completed. $56 \%$ of men and $57 \%$ of women respondents fall in this range, with slightly more women having completed college (Table 47 ). It will be noted that slightly more men than women have graduate degrees.

Tables 48 and 49 represent a composite picture of the ways in which occupations have changed for members since their joining the cooperative household. Forty-five professional and semi-professional occupations were 
held by members before joining compared to twenty-four after, with slightly more women than men before and after. The student category also changed considerably, the total of twenty-seven who were students before joining dropping to twelve after. The other major occupational change was away from the "clerical service" category (from twenty-six before to eight after). Men and women gave fairly similar answers when questioned about the reasons for group formation. Answers "focusing on group support and/or strengthening of relationships" were the largest group ( sixteen for men, fourteen for women), with "living as a group with compatible people", "value system"and "economics" also receiving many responses. (Table 50). Personal reasons for joining followed similar emphases (Table 51), with the added category of "a specific personal relationship" accounting for thirty-five responses (twenty-two men and thirteen women).

Time lived in the current group was spread over a wide range, with $48 \%$ of the respondents resident fifteen months or less and $34 \%$, sixteen months or more (Table 52 ). A fairly large number (4l\%) have had previous group experience, mostly in only one or two groups $(30 \%) .29 \%$ had two years or less experience in other cooperative households (Tables 53,54,55).

Over a quarter ( $30 \%)$ of the reasons listed for people leaving cooperative households fall into the category of interpersonal conflicts, with other responses spread over a wide range of reasons (Table 56). Current members 
of groups seemed fairly stable in that over half ( $51 \%$ ) indicated they planned to rema in indefinitely and only $9 \%$ specified intent to leave within the next six months (Table 57 ).

\section{Sex role information}

The balance of the tables in the respondent information section contain data derived from sex role questions. It will be noted in the questionnaire (Appendix B) that certain questions pertained to mutually exclusive groups of respondents. However, because a few persons answered questions designed for both groups, some overlap in data resulted. All of the data represents perceptions of men and women regarding various aspects of sex role development as they have experienced these.

Table 58 concerns data considered by Hypothesis three and will be discussed in the next section. According to Table 59, these discussions centered heavily around the issue of household responsibility ( $39 \%$ of all issues ) with women somewhat more concerned than men (sixteen to eleven). Table 60 shows that men perceive that similar issues are discussed more frequently than women do. When a Yule's $Q$ is computed for this data it indicates a moderate positive association $(+.38)$ between sex ( male) and answering occasionally to very often rather than never or rarely. This means that we would do $38 \%$ better than chance in predicting that men in our sample would respond occasionally to very often rather than never or rarely. The central 
issue in such ongoing discussion is seen again to be household responsibility (Table 61 ). $38 \%$ of issue responses were in this category.

Table 62 (consisting of those respondents who moved in after formation) indicates the same trend as seen in Table 60 , with men perceiving that sex roles are discussed more frequently than women do but without so large a difference. A Yule's $Q$ of +.21 reveals a low positive association between sex (male) and answering occasionally to very often rather than never or rarely. This means that we would do $21 \%$ better than chance in predicting that men in our sample would respond occasionally to very often rather than never or rarely. Again (as in Tables 59 and 61 ) household responsibilities ( $37 \%$ ) accounts for the largest porportion of the issues discussed ( Table 63 ).

Since Table 64 concerns data considered by Hypothesis one, it will be discussed in the next section. Table 65 shows that women list somewhat more dissatisfactions than men do. A Yule's $Q$ of +.32 means that there is a moderate positive association between sex (male) and listing more satisfactions than dissatisfactions. This means that we would do $32 \%$ better than chance in predicting that men in our sample would list more satisfactions than dissatisfactions .

Table 66 seems to indicate upon first glance that there is little, if any, difference between the extent to which men and women feel group decisions 
regarding sex roles have become reality. Nevertheless, when a Yule's Q is computed $(+.25)$, a low positive association is revealed between sex ( male) and answering not at all (1) to the middle point ( 3 ) rather than answering (4) or very much ( 5 ). This means that we would do $25 \%$ better than chance in predicting that men in our sample would answer on the low end of the scale. Table 67 shows that "commitment" ( $18 \%$ of the responses), "interpersonal support" ( $21 \%$ of the responses) and "group expectations or agreement" ( $25 \%$ of the responses) are thought to be the principle factors aiding the process of group decisions regarding sex roles becoming reality. Women especially see "commitment" ( $22 \%$ of the women's responses and $13 \%$ of the men's responses) and "interpersonal support" ( $27 \%$ of the women's responses and $13 \%$ of the men's responses ) as being more important than the men do. The factor seen as most important in hindering the process of group decisions becoming reality ( Table 68 ) is "previous lif e experience" ( $36 \%$ of the responses) with men and women listing this response an equal number of times. $18 \%$ of the responses were in the category of "internal practical difficulties" with that response again equally divided between men and women. Again, since Table 64 concerns data considered by Hypothesis one it will be discussed in the next section. Table 70 also shows a trend similar to Table 65 in that men have a tendancy to list satisfactions regarding development of sex roles rather than dissatisfactions. A Yule's $Q$ of +.34 
indicates a moderate positive association between sex ( male) and listing satisfactions rather than dissatisfactions. This means that we would do $34 \%$ better than chance in predicting that men in our sample would list satisfactions rather than dissatisfactions.

Regarding whether or not respondents see communes as potentially having a unique influence on the development of sex roles in the larger society (Table 71 ), response was overwhelmingly in the affirmative with $78 \%$ of the women and $77 \%$ of the men responding "yes". Table 72 shows that $81 \%$ of the responses regarding how this influence will be made are in the category of "as an alternative". Men and women responded fairly evenly in this and all other categories.

Table 73 again shows household responsibilities to be a major concern of respondents, especially of women. $30 \%$ of the responses to the question of what kinds of differences respondents expected in sex roles from the traditional nuclear family were in the " household responsibilities " category. This included $36 \%$ of the women's responses and $20 \%$ of the men's responses. The next most common response was in the category of "general roles"with $24 \%$ of the responses ( $41 \%$ of the men's responses, but only $10 \%$ of the women's responses ) in this category.. It can be seen further from Table 73 that respondents overwhelmingly expected differences to be in the direction of less differentiation in sex roles ( $93 \%$ of the responses). 
From Table 74 it can be seen that respondents list "assertive" ( $29 \%$ of the responses) and "passive-withdrawal". ( $29 \%$ of the responses) equally as their most common responses to conflicts existing between the larger society and their values regarding sex roles. These responses are almost evenly divided between men and women. Table 75 shows that respondents (both men and women) are almost evenly divided between reporting "yes" or "no" to the question of whether their ideals regarding sex roles have changed as a result of communal living. Of those who responded "yes", $77 \%$ see their ideals regarding sex roles as having become more equal with responses almost equally divided between men and women (Table 76 ). "Personal growth and maturation" ( $30 \%$ of the responses) and "interpersonal support" (23\% of the responses) were most often seen as leading to these changes in ideals (Table 77). Again these responses were almost equally divided between men and women.

Table 79 shows that $57 \%$ of those who responded see responsibility for the activities listed on the grid (Question 21 in Appendix B) as having changed over time. It can also be seen that men are more likely than women to see the activities as having changed. Regarding how the pattern of responsibility for these activities has changed over time, Table 80 shows that the categories of "activities cross traditional sex lines" and "activities are neutral" are used about equally with the cat egory of "activities follow traditional sex 
lines" used much less. Almost twice as many men as women see activities crossing traditional sex lines. No particular pattern emerges from Table 81 regarding why the pattern of activities has changed, although "individual preferences" and "practical considerations" receive the most number of responses of those that were specified and codable.

Table 82 indicates that there is very little difference between men and women in the direction of new activities done since joining the commune, but that there is a tendancy to list activities which cross traditional sex lines. $46 \%$ of the responses were "activities cross traditional sex lines", $22 \%$ were "activities are neutral" and $32 \%$ were "activities follow traditional sex lines".

Hypotheses

This section will summarize the data tabled to test our tentative. guiding hypotheses. The data is contained in Tables 58,64,69 and 83 111 in Appendix $F$.

\section{Hypothesis one}

The first hypothesis states that there is a difference in how men and women report levels of satisfaction with decisions ( if there were decisions ) or with development of sex roles (if there were no decisions). It can be seen from Tables 64 and 69 that there is not a great deal of difference between men and women on these two factors. Collapsing the data as was 
done in Tables 83 and 84 yields similar results. Table 83 clearly shows that there is no purpose in doing a Yule's $Q$ as there is only a difference of one response between men and women. It can be seen that the results would be negligible. Table 84 demonstrates a slight difference which when put to the Yule's $Q$ statistic yields a $Q$ of +.24 . This means that for our sample we would do $24 \%$ better than chance in predicting that the most satisfied are males and the least satisfied are females. In other words there is a low positive association between being male and having a high level of satisfaction.

Looking further into hypothesis one by computing percentages of those who responded in each category ( see Tables 85 and 86 ) we see that in Table $85,15 \%$ of the women who responded to the question answered in the two least satisfied categories ( 1 and 2 ) while $3 \%$ of the men responded similarly. There was a tendancy for men to respond in the middle category ( 3 ) more than women. $15 \%$ of the men and $3 \%$ of the women responded with a (3). Also on the same table, $79 \%$ of the women and $84 \%$ of the men responded on the satisfied end ( 4 or 5 ).

A similar pattern occurs on Table 86 with $20 \%$ of the women responding in the two least satisfied categories in contrast to $0 \%$ of the men. The middle category ( 3 ) included $25 \%$ of the women and $33 \%$ of the men. Finally, 
the trend continues to the two most satisfied categories including $55 \%$ of the women and $66 \%$ of the men.

\section{Hypothesis two}

The second hypothesis states that there is a difference in how men and women perceive task division (household by household). Tables 87 through 104 deal with this hypothesis. The total number of male and female respondents in each household must be taken into consideration in order to look at the figures in a meaningful way. Therefore, percentages of the totals (as done in Table 109 for a different hypothesis ) need to be computed before any sense can be made of the data. We computed percentages of the totals where there was a sufficient number of answers in a given category and where there was considerable difference between male and female perceptions. Percentages for the "e" category (done equally by men and women) were computed for almost all of the tables. This is because the most responses were in this category and because the category seems a significant one to us.

In Table $87,37 \%$ of the women's answers are e's in contrast to $67 \%$ of the men's answers. It can be computed from Table 88 that $21 \%$ of the women's answers and $11 \%$ of the men's answers were d's (mostly done by women). There is also difference between men and women on the percentage of e's with $44 \%$ of the women's responses and $60 \%$ of the men's responses being $e^{\prime} s$. 
In Table 89 the percentage difference is less and in the opposite direction with $60 \%$ of the women's responses and $56 \%$ of the men's responses being e's. Table 90 had no men respondents so no comparison can be made; however, $40 \%$ of the women's were e's which is close to the percentages in Tables 87,88 , and 89 .

It can be computed from Table 91 that there is a difference between men's and women's responses in several categories. To name a few, $0 \%$ of the women's responses were a's (done entirely by men), but $8 \%$ of the men's responses were a's. $10 \%$ of the women's responses were d's (mostly done by women) in contrast to $0 \%$ of the men's responses. The percentage of "e" responses followed a pattern also found in Table 89 with women responding with $48 \%$ e's and men responding with $42 \%$ e's. In Table 92 the significant differences between men's and women's responses are found in the "b" and "e" categories. 30\% of the women's responses are b's (mostly done by men) in contrast to $17 \%$ of the men's answers, while $30 \%$ of the women's responses are e's and $45 \%$ of the men's responses are e's.

From Table 93 it can be computed that there is a difference between men's and women's perceptions in that $15 \%$ of the women's responses but only $8 \%$ of the men's responses are d's (mostly done by women). Also only $20 \%$ of the women's responses are e's in contrast to $40 \%$ of the men's responses. There is much less difference and the difference is in the opposite direction 


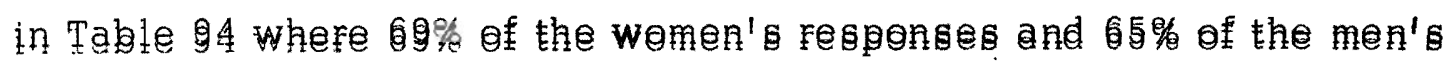
responses are e's: This trend continues but in lesser magnitude in Table

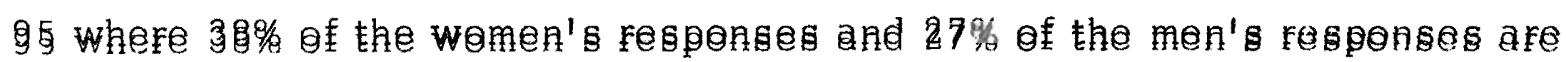

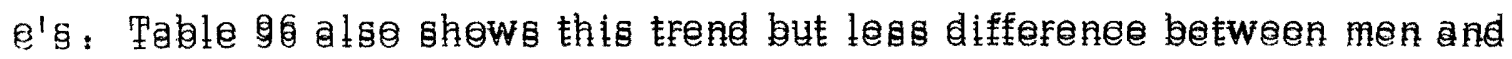

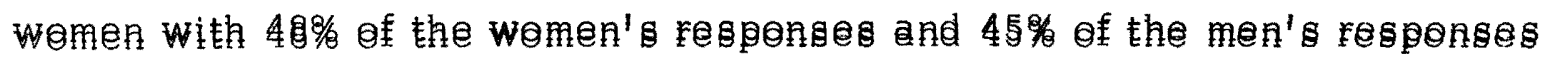
being e's: Table 97 indideter the same small difference between men's and women's perceptions a a Table gr but in the opposite direstion a gain.

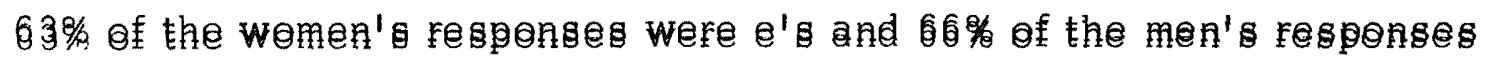
were e's:

The differenee between men's and women's perceptions diverges a little more and changes difection a gain in Table 9o where $60 \%$ of the

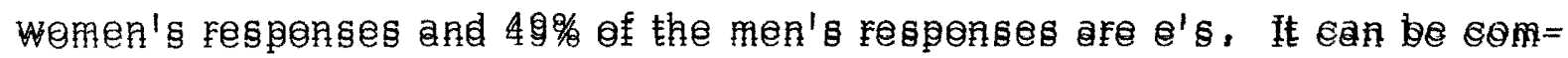
auted from Table go that there is a difference between men's and women's fespenses in that g\% of the women's respenses in eontrast to $0 \%$ of of the men's respenses afe e's (done entirely by women). Also in Table 90, 20\% of the

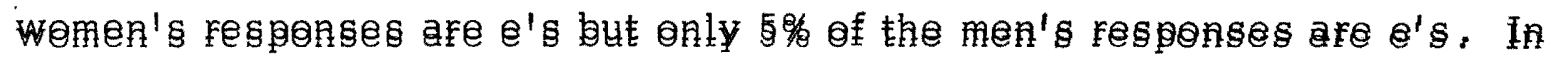
Table 100 the percentage of e's fires dra stically again but in the same direction With 78\% af the women's responses being e's in contrast to only $44 \%$ of the

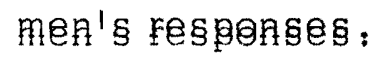


Going on to Table 101, the percentage of e's drops again but the difference between men and women is apparent with $35 \%$ of the women's responses as e's contrasted to only $15 \%$ of the men's responses. Table 102 has no male respondents and comes from a group with no male residents so the results are different but self-explanatory. Table 103 shows a difference in perception between men and women but only a slight one, with $43 \%$ of the women's responses and $50 \%$ of the men's responses as e's. In Table 104 the smallest difference between men's and women's perceptions in category " $\mathrm{e}$ " is found with $33 \%$ of the women's responses and $35 \%$ of the men's responses being e's. However, $18 \%$ of the women's responses were d's (mostly done by women) in contrast to $8 \%$ of the men's responses. Hypothesis three

The third hypothesis states that there is a difference in how men and women report perceptions of whether sex roles were discussed at formation. The data contraindicates the validity of this hypothesis as can be seen from Table 58. Also when a Yule's $Q$ is computed it is -.07 indicating only a negligible correlation. Further, a use of percentages as in Table 105 demonstrates the same lack of any strong difference between men and women on this question.

\section{Hypothesis four}

The fourth hypothesis states that there is a difference between rural and urban groups in perceived task division (divided by sex ). Information 
from Tables 106 and 107 was used to compile Table 108 which will be addressed here. From Table 108 it can be seen that there really is not very much overall difference between the perceptions of rural and urban groups. Most of the percentages are just a few points apart. The most difference shows up in categories "e" (done equally by men and women) and "i" ( not applicable) with urban women having $41 \%$ of their answers as e's, urban men $46 \%$, rural men $52 \%$, and rural women the highest with $54 \%$. Still this is only a range of $13 \%$. The " $i$ " category contains a range of $11 \%$, from $17 \%$ for urban women to $6 \%$ for rural men.

Hypothesis five

The fifth hypothesis states that there is a difference between rural and urban groups in new activities undertaken since joining ( divided by sex ). The raw data from Table 109 needs to be put into percentages to be meaningful. In cross-sex activities $(+)$ there is a slight difference but not purely between urban and rural because $42 \%$ of the rural women's answers, $39 \%$ of the urban men's answers, $33 \%$ of the urban women's answers, down to $32 \%$ of the rural men's answers are in this category. The data shows slightly more same-sex activities ( - ) done in rural groups with $29 \%$ of the rural men's answers, $21 \%$ of the rural women's answers, $15 \%$ of the urban women's answers and $8 \%$ of the urban men's answers. Neutral activities (o ) also show a variance but one fairly heavily weighted with urban responses. 


\section{Hypothesis six}

The sixth hypothesis states that there is a difference between rural and urban cooperative households in members' satisfaction level (divided by sex). Tables 110 and 111 deal with this and do show a trend for urban groups to answer more readily on the dissatisfaction end of the scale with women responsible for most of the dissatisfaction responses. Hypothesis seven

Hypothesis seven is not tabled for reasons discussed in the next section

Hypothesis eight

Hypothesis eight states that satisfaction level is associated wtih perceived task division (divided by sex). Data to test this hypothesis was not tabled for reasons listed in the next section. Nevertheless, some effort was made to test it anyway by comparing satisfaction level percentages from Tables 87 through 104, but no clear trend could be seen at all. 


\section{CHAPTER V \\ INTERPRETATION OF FINDINGS}

Commune information

The dominant feature of the data obtained from the commune questionnaire seems to be the reflection of greater stability evidenced by rural households as compared with urban groups. Rural groups were generally of somewhat longer duration and were more likely to own their property than were urban members of the sample. One possible explanation for this apparent greater stability might be the major investment of time and energy required for survival in a rural environment. Where months of hard physical labor are required just to provide a minimum of food and shelter, much commitment and adaptibility are demanded of group members . In fact, the period of letdown which follows the initial phase of building and land reclamation was mentioned in one group as the point at which some members lost their sense of purpose and even moved out of the community. In contrast to the difficult physical conditions present for rural groups, urban households face stresses particular to their setting. Generally, less privacy is available for members, more intense contacts with the outside society exist, and more rapid changes bombard the urban group. This may be one explanation for the presence of more formal means for maintaining group solidarity. For example, a number of urban groups listed "similar values" as a basic criterion for membership, as opposed to the less stringent "personal 
interest in belonging" which was mentioned most often by rural respondents . Also, urban groups tended to feel the need for more frequent regular group meetings to talk over problems and maintain communication and sensitivity. The difference in space available may be one simple but important factor in group organization and stability. Urban groups were mainly confined to large single houses, where rural groups were able to provide space for larger numbers and still maintain areas of privacy for those who desire them.

One other interesting piece of data relates to members' financial support of the group. We expected to find that rural groups would more easily absorb a few persons unable to contribute financially , However, this provision is seen more often in the urban part of the sample. A fa irly high proportion of the urban groups are oriented to community service and political action. In this context, members engaged in such activities are sometimes freed of financial obligations and supported by the rest of the group. This factor may account for the above trend. Respondent information

\section{Base data}

The profile of the research sample reflects what might have been expected on the basis of our reading. Most respondents were fairly young, well educated white persons. Many had dropped out of professional pursuits or other occupations to be involved in jobs related to their search for 
community and new personal meaning. We did not observe any regret over the loss of income or vocational satisfactions which might have resulted in some instances. This was especially noticeable among rural respondents, where a more radical break with past life styles was usually represented.

The orientation reflected in reasons for group formation and individual decisions to join was personal more often than ideological. This emphasis may reflect Kanter's ${ }^{\prime}$ observation that modern cooperative groups have moved away from efforts at large social alternatives to more intimate family alternatives.

Although many respondents have tried more than one group, this does not seem to have caused disillusionment. At the time of response very few planned to leave their groups soon and many commented on their doubt that they could ever again live happily without the stimulus and support afforded by cooperative living. Most seem to recognize that interpersonal relations are the point of greatest stress in group life, but they seem able to accept this and to continue working for improved relationships.

Sex role data

Data seems to support the interpretation that persons living in cooperative households are fairly well aware of sex role issues as an area of considerable social importance. In a number of groups respondents expressed surprise at our studying this question in cooperative households, remarking that equality of sex roles or lack of stereotyping was an underlying as sumption in their group life. They did not consider the subject an issue any longer in 
their setting.

In spite of these disclaimers there were differences in perceptions. as to consideration of and resolution of questions related to sex roles. Overall, men had somewhat more neutral or satisfied responses, whereas women seemed to feel more dissatisfactions with both decisions and sex role development. As indicated by the data for Hypothesis six there is some tendency for urban groups to indicate more dissatisfactions than rural groups. Aga in it will be noted that women's responses account for most of this trend.

In formulating Hypothesis three we anticipated a difference in awareness by men and women of early sex role discussions. We expected that men might tend to forget such discussions as the issues would probably not seem so personally central to them. The data does not support this expectation. When responses regarding ongoing discussions are considered, it will be noted that men actually perceive more frequent discussions of such issues. Differing interpretations can be given this tendency. On the one hand, it may be interpreted that men are equally sensitive to sex role is sues and therefore are aware of discussion in both early and ongoing stages of group life. On the other hand, especially in relation to ongoing discussion, it is possible that men really feel overly sensitive about these issues, being placed somewhat on the defensive. 
When perceptions of the process of klowls becominu roully ullo compared, we find what might be characterized as rather traditional feminine and masculine responses. Women's responses focus on relational elements, "commitment" ( to the group ) and "interpersonal support", where men's responses show some concentration in the more external catagory of "group expectations and agreements". Since men's responses are more scattered, the interpretation is not as strong as that for the women respondents. Men and women are both very aware of the role of "previous life experience" in hindering the realization of equalitarian goals. This sensitivity to early socialization and its impact on many facets of cooperative life was very evident in informal conversations in almost all groups visited.

From an examination of questions dealing with comparisons between cooperative group life and the larger society, it can be seen that respondents seemed very aware of contrasts and of their stance as cooperative households. Most respondents see cooperative group life as having some impact on society. Usually this influence is seen in terms of providing an alternative to the isolated nuclear family. This is not so much as a model for society as a whole, but as a workable option for those persons seeking alternatives for themselves. In terms of expected differences in life style women tended to focus on the highly visible practical areas of household responsibilities. This reflects the same tendancy noted among female respondents in relation to types of 
issues raised in group discussion. With regard to expected differences between cooperative living and the nuclear family, men's responses clustered around general roles. This greater generality among men could represent either a broader approach or a lack of precise thought regarding specific implications. However differences are defined, both men and women definitely expect cooperative Living to produce movement toward less differentiation between sexes. This strong response would seem to imply that this is an important value for persons joining cooperative households, although it is not so listed by respondents. As mentioned earlier, perhaps the feeling of this being an implied assumption kept it from being seen as a conscious reason.

When members' response to outside social conflicts regarding sex roles is examined, most response's are seen as either positive or relatively neutral. This may mean that members do feel some sense of responsibility for interpreting their way of life to the larger society or at least of seeking to avoid negative impressions. Consistent with this approach is the objection of some respondents to the term "commune". The emotional overtones associated with this term were seen as likely to produce an automatic negative response to the study. A sense of responsibility would be a reasonable stance in view of their understanding of themselves as demonstrating alternatives to traditional forms of family organization. A number of groups have seen 
their constructive approach to the community result in relationships of trust and support with persons who began by viewing them with suspicion and hostility.

When task division is considered, the only meaningful way to deal with the resultant data is in terms of male and female perceptions in each household. In nine groups there was a variation of $10 \%$ or more in the degree to which men and women saw tasks as equally divided. This variation is considerably more prevelant in groups with a loose structure for defining responsibilities. Four out of the $\mathrm{six}^{3}$ rural groups in the sample demonstrated this wide variation. All but one of these are quite loosely structured. The more organized household is one living temporarily in a town. In this group the women see the men as doing more to equalize responsibilities in the current transitional phase, but expect this to balance out when the move to their farm is accomplished. When rural and urban groups are completely separated, the difference seen is a very slight trend toward rural respondents seeing tasks somewhat more equally divided. When placed alongside other data and observations this trend appears consistent with rural responses in related areas.

Overall in the rural groups we received the impression that women felt men had made a greater adjustment in taking on traditional female tasks and roles than had been true for them in regard to traditional male tasks. In some 
ciscs they expressed self consciousness about this. The lack of need for special skills required for household chores was seen as one reason for ease of crossover. Also, women felt that they were not under pressure from men to learn equipment repairs and other traditional male skills unless they were especially interested. Men may feel especially obligated to engage in the often less interesting and more regular tasks of cleaning and cooking. In urban groups men occasionally expressed frustration at not being able to maintain a flexible schedule of outside employment and internal responsibility. It would seem that external employment demands are a major barrier to sex role goals becoming reality, especially in the areas of child rearing and household tasks. In spite of this, the divurgence in urban households shows men as seeing work more equally divided than women do in three of the five urban groups reflecting a variation of $10 \%$ or more in male/female perceptions related to task division. This may reflect one interesting factor which was mentioned in several urban groups, that women seem more apt to take initlative in general cleaning and picking up where men may be satisfied with a lower level of ongoing maintenance.

When they were asked to identify new task experiences, both men and women appeared to see themselves as moving into increased numbers of cross sex tasks. As was noted in the discussion of data for Hypothes is five, it is impossible to associate either the rural or urban setting with a larger number of increased cross sex activities. However, in terms of increase of same 
sex tasks, it can be said that the rural groups demonstrate more of this tendency than do urban groups. This may reflect the need for all to learn new tasks which may be traditionally sex linked, but are specific to the rural environment. Canning, care of livestock, construction and large scale gardening are some examples that were observed. Generally, the question on this subject left so much latitude for response that any interpretation must be seen as very tentative. Responses to this question also pointed out one of the areas which our study was unable to explore adequately and one in which many respondents expressed interest. By limiting our questions to task type roles we hoped to gain some objective view of the practical outworking of ideals. At the same time this excluded the whole range of emotional roles in which a great deal of experimentation is going on. One woman respondent sent a followup letter in which she discussed the importance of her group to those who were learning to be freer to express emotional qualities which haverbeen traditionally associated with the opposite sex. In spite of the limitations of the questionnaire in this regard, we feel we gained a great deal of understanding of some of the dynamics involved in the expression of emotional roles. 


\section{Footnotes for Chapter $\mathrm{V}$}

1. Rosabeth Moss Kanter, Commitment and Community, p. 166.

2. See pages $2-3$ of this study.

3. One of the two remaining had no male residents so cannot be compared. 


\section{CHAPTER VI \\ DISCUSSION AND CONCLUSIONS}

Introduction

As we discuss our findings, the reader should realize that there are certain limits to this study. These limits may have introduced bias or skew in the data collected and should be taken into consideration when evaluating the discussion and conclusions.

We encountered limits in defining our population since we wanted to draw a sample which was heterogeneous enough to make some comparisons and homogeneous enough to be considered reasonably definitive. We are satisfied with our definition and think each group in the sample is appropriate, but we recognize there could be some room for disagreement regarding "common values and interpersonal commitment". Some bias also may have been introduced in drawing the actual sample, as we were limited to groups which were accessible and known to us. Again, it must be emphasized that we are not attempting to generalize beyond our actual sample since it could not be selected randomly.

The questionnaires also have certain limits which were discovered through questions asked by respondents and through attempting to code and compile the data. Specifically, respondents had trouble following the format on Questions 16 and 22 on the Commune Information (Appendix B). On the Respondent Information (Appendix B ) Questions 13b, 13d and 14b were ap- 
parently not clear enough as respondents often did not pair the is sue they listed with the decision relating to that issue or simply did not list the is sue or decision. This resulted in the necessity of adding the coding categories "issue not listed" and "decision not listed". Questions $15 \mathrm{~b}$ and $16 \mathrm{~b}$ also could have been more specific as we did not get the information we were seeking. It probably would have been better to ask the areas in which their satisfactions and dissatisfactions were and the nature of these satisfactions and dissatisfactions. Question 21 (the grid) also has some shortcomings. The task of who speaks for the group to outsiders stimulated some respondents to question whether it would have been better to distinguish between who actually does the speaking and who decides what is said. Many respondents wrote in "Consensus" as a method of assignment for some tasks. Perhaps others would have used that alternative if it had been included in our list of possible answers. Also on Question 21, many respondents missed the fact that "mostly mothers ", "mostly fathers" and "both parents equally" could be used as answers for the questions relating to children, possibly making the validity of responses on those tasks questionable. More generally, we also discovered during administration of the questionnaires that the questions somehow did not elicit expression of emotional areas of functioning nearly as much as we had expected. Many respondents wanted to discuss such things afterwards but stated that they did not see the question- 
naire as asking for that kind of information.

The process of collecting the data also had certain limits and revealed others. Some of these were discussed previously in the Methodology section. Again, as in drawing a sample of groups, availability and willingness determined who actually participated from each group. The change in administration of the instrument from doing interviews to having respondents fill out their own questionnaires resulted in some of them not following directions as carefully as we would have in interviewing them. Thus, some answered both Questions 13 and 14 and/or 15 and 16 on the Respondent Information (Appendix B) when the questions were labeled as mutually exclusive: Several questions regarding the meaning of "ongoing couple relationship" lead us to question the usefulness of the information gathered in that area as there was so much confusion and room for self-definition. Our presence while the questionnaires were filled out also seems an important factor. The rapport we were able to achieve with most groups seems an advantage to the study. Nevertheless, the inability to develop the same degree of rapport with all groups may cause some skew in the data.

When the open-ended questions were coded, other limits of the study emerged. As stated previously in the Methodology section, we found it necessary to change some of the coding categories to reflect responses more adequately and to tighten and clarify meanings of some categories (see Appendix 
E for actual changes). Since this was done after the data was gathered, some bias may be reflected. Our negotiations in the coding process, also discussed in the Methodology section, may also have introduced bias, although we do not think so. A specific limit which emerged during the coding process was ourdifficulty in coding Question 20a from the Respondent Information (Appendix B ). Seven responses reflected changes in practice rather than changes in ideals and were thus seen as "uncodable".

In compiling the data, certain limits also emerged. Questions 15 and 16 in the Respondent Information (Appendix B) are not parallel so must be considered separately.. Further, those who answered Question 15 did not have an opportunity to report how satisfied they were with the development of sex roles rather than just with the decisions regarding sex roles. Limits were also discovered while compiling data to test the hypotheses. Hypothesis seven states that satisfaction level is associated with frequency of discussion of similar issues. It was not feasible to test this hypothesis because the frequency of discussion question was divided between those present at formation and those joining after formation, while the satisfaction question was divided between those answering concerning decisions regarding sex roles and those answering concerning development of sex roles. Hypothesis eight also was not feasible to test. It states that satisfaction level is associated with perceived task division. When attempting to compile the information to test this hypothesis, it became clear that we only gathered 
information on satisfaction with decisions regarding sex roles and satisfaction with development of sex roles but not on satisfaction with perceived task division. Therefore to test how satisfaction level is associated with perceived task division is meaningless. The reader will note that we gathered considerable information which was not used in specific hypotheses statements. When we embarked on this study we were uncertain regarding what information would be most useful to study further. Our final decision of which data to study thus was made on the basis of time, focus of interest and observations made while gathering the data. Thus, although base information is tabled and discussed, we chose to use sex role information to test in our hypotheses. Further, it became readily apparent that there were not enough children in the sample to make it worthwhile to compile and interpret the data relating to them. Therefore, we excluded it from our consideration. Conclusions

We have reflected on our reading, data and interpretations and on observations made during the course of this study in order to come to some conclusions.

The literature alerted us to be sensitive to the distinction between groups which are retreating from society and those which are seeking, directly or indirectly, to change society. Our sample generally reflects the latter category of group; however, it may be somewhat skewed because of certain 
factors involved in the sample selection. Because of the nature of our questionnaire we wanted groups who had been in existence for several months. We relied heavily on personal friend ship connections for location of several groups and often a group visited would refer us to others. The last two reasons especially might tend to result in groups being somewhat similar. Respondents in our sample impressed us with their sense of responsible relationship to the larger society even though rea sons for joining were largely personal. This sense of relationship is in some cases embodied in direct effort to change society and its institutions; however, a more prominent focus is on the development of viable options to the nuclear family, which may be seen as an indirect way of effecting societal change.

Carl Rogers 1 points out that the nuclear family, as we know it in the Western world, has a history of only five or six decades. Many students of the modern family have discussed the problems faced by such family organization, especially the isolation and exclusive interdependence of the family unit and its alienation from any larger social context. In addition to what can be found in the literature, it seems to us that the nuclear family in its most isolated form is largely a phenonemon of the white middle and upper classes. The term "isolated" is meant to convey a lack of readily available support groups such as relatives, neighbors and ethnic groups. A brief survey of lower economic and ethnic groups indicates tendancy toward a wider network of family and neighborhood ties related to less mobility and other factors, 
which may in some cases reflect cultural preferences and in other situations, lack of opportunity for social movement. With this background, it may be significant to note the high proportion of white, generally well-educated, middle class, mobile persons in our sample. Most of these persons have been raised in isolated nuclear families and expressed feeling a deep lack of the kind of support and stimulus that might be available in a larger family system

From some of the data collected one could conclude that many respondents are seeking some form of larger family system. Personal rather than ideological reasons for joining, expecially reasons implying desire for group involvement, were emphasized. Further support of the above conclusion is found in their intent to remain in the group setting despite their seeing interpersonal difficulties as a major point of stress. Also, the tendancy to see their effect on the larger society as being primarily an alternative to the isolated nuclear family gives additional credence to this conclusion. Comments made during our visits also reflected desire for inclusion of more older people to enrich the family atmosphere. Thus, we see the search for a more extended type of family organization as a major thrust of our respondents.

One of the basic assumptions for persons entering this more extended form of family organization appears to be less differentiation between the sexes than is present in the nuclear family. Even with this assumption, the data indicates that there are still many unresolved problems surrounding this 
issue. These may be considered as related to those unique elements which men and women bring to any family organization. Historically, in the Western world, men have occupied a position of power and privilege in many areas in relation to. women. This position has resulted in more acute sensitivity on the part of women of the disadvantages of their role and less necessity for men to examine their own status in relation to women. Even in segments of the society in which equalitarian goals have been revered, this power relationship has not basically changed without women organizing to address this issue. An example of this can be seen in the awareness of women in the anti-war movement of their automatic relegation to organizational "housekeeping" as when they ran the mimeograph machine made the coffee while men organized and gave the speeches. 2 Emergence of the modern Women's Movement has challenged that basic power relationship and has enabled women and in some cases men, to be sufficiently free of prior role definitions to engage in more nearly equal opportunities for defining their own roles. For example, one male respondent stated that his sex role ideals had changed not as a result of cooperative living but as a result of the Women's Movement.

In spite of progress seen from the Women's Movement, a legacy of socialization into traditional male and female roles still persists. Respondents conveyed a very realistic awareness of the constraints imposed by this social- 
ization. This socialization produces ideal role expectations for men and women. The ideal role for a women is to become a wife and mother and the ideal role for a man is to gain a wife and children and to provide for them. Illustrating this socialization is the observation made by many women respondents that they found themselves automatically responding to clues such as dirty dishes or clutter because of their conditioning, while men often did not even perceive these as potential tasks.

In addition to the more personal conditioning which men and women undergo, there are structural elements in society which impede progress toward equalitarian goals. One of the most significant of these is the pattern of employment opportunities. There are few satisfying job opportunities for persons who desire a flexible work schedule. This places men in the position, as mentioned by several male respondents, of being forced to take full-time positions at the expense of not being able to share more equally with women in household tasks and child rearing. In addition, a number of respondents noted that many of the jobs available to women provide lower salaries than similar ones available to men. The economic needs of the cooperative household thus sometimes require that the men seek outside employment. Another significant structural element in society is the absence of day care provisions to meet the needs of the changing role of women. A model which might be examined is the program developed in some other nations, especially Sweden 
where day care is provided at the actual work locations of parents. This was not a current need for many of the respondents who do not have children, but was seen as a factor which hinders realization of equalitarian goals. The presence of the historical, socialization and structural factors which have been discussed above provide a background for understanding the respondents' perceptions of issues surrounding sex roles. We see these factors providing a partial explanation for role dissatisfactions and varying perceptions related to sex role issues and task division found among the respondents .

Thus, our study supports much of what we have seen in our reading, suggesting that in spite of the progress made, there are still real barriers to the realization of equalitarian goals in cooperative living and in society in general. Increasing numbers of viable options for life-styles are becoming available to both men and women, although the mode of cooperation which many of these options imply still faces the dominant spirit of competition prevalent in most of American society. As discussed in the literature review, in the more rigidly structured and less mobile society of an earlier period, many of these options were not really viable for most people. In the context of modern American society, which reflects disillusionment with the nuclear family and a general breakdown of intimate social ties, a loosening of previously accepted strictures has occurred. This can result in either movement toward a more cooperative society or more authoritarian forms. Both of these 
trends can be readily seen in contemporary American society. We think the success of cooperative households, such as those seen in our study, could have far reaching impact in contributing to a determination of the direction in which American society may go. 
Footnotes for Chapter VI

1. Carl Rogers, On Becoming Partners ; New York, Dell Pub. Co., 1972, p. 72 .

2. Jane Alpert, "Forum - Mother Right - a New Feminist Theory ", Ms. ,vol. 11, no. 2, August, 1972 . 
CHAPTER VII

\section{EPILOGUE}

As we reflect on our study, we have a natural inclination to wonder what further exploration in this area might produce. Some of the following ideas for future study were suggested to us by respondents in our research, some come from our curiosity about how certain factors we did not include in our study might effect sex roles in cooperative households and some involve longitudinal research which was not feasible for us to do.

As mentioned in both the Interpretation of Findings and Discussion and Conclusions sections, the area of emotional roles was of concern to our respondents and seems of importance if one is to understand the full effect of cooperative living on the development of sex roles. We think it might be interesting and illuminating to select specific emotional roles which have been traditionally repressed by each sex and determine. to what level these have been freed up to allow all persons (male and female) to have the full range of human emotions at their disposal. For example, have men found it easier to cry, to relate more sensitively to other persons, to nurture others and to develop intuitive capacities, etc. ? Have women found it easier to beassertive. about their wishes and ideas, and to be comfortable in assuming positions of leadership, etc.?

In addition, to the study of emotional roles, we see the areas of structure and leadership and how they effect the development of sex roles in cooperative 
households as interesting topics for future study. We discovered that the presence of varied levels of structure for task division, decision making, etc., has an influence on how sex roles developed in our sample, but our own research in this area was not precise enough to make strongly supported conclusions. We did not collect any formal data on leadership patterns in our sample, but also see this as an area which might reveal some interesting effects on sex role development. Our observations and reading seem to indicate that the presence of a strong male leader may inhibit the development of an equalitarian group, but also that the absence of any leadership and/or structure may result in the lack of focus, direction, and consciousness necessary to achieve equalitarian goals. Thus, further study might yield some explanation in these areas.

Further study might also be enhanced by three rather limited, but possibly illuminating, suggestions made by our respondents. These were that changes in the mode of relating to the opposite sex, changes in stereotypes of the opposite sex and changes in expectations for couple relationships as a result of cooperative living might be interesting to research.

All of the above suggestions could be carried out in studies similar to ours; however, the following ones would require research of a longitudinal nature. Changes in expectations of couple relationships could be expanded into a longitudinal study designed to explore what happens in terms of sex roles to those with experience in cooperative households who later go on to 
form isolated nuclear families. Another area which would require longitudinal study and which is very interesting to us is the is sue of child-rearing for more equalitarian sex roles. A comparison over time of groups which make conscious effort for socialization into equalitarian roles and those where no conscious effort is made might yield some llluminating and useful material.

Thus, as can be seen, we have ended our research with more questions than we had when we began; however, now our questions are somewhat more focused and are based on actual experience with our topic rather than on arm-chair philosophizing and the reading of related literature. 
Bookss

1. An Intentional Community Handbook, Community Service, Inc., Box 243, Yellow Springs, Ohio, 45387, 1974 .

2. Ballou, Adin, History of the Hopedale Community, from Its Inception to Its Virtual Submergence in the Hopedale Parish, ed. William S. Heywood, Philadelphia, Porcupine Press, 1972 (Reprint of 1897 edition).

3. Bell, Norman W. \& Vogel, Ezra F., A Modern Introduction to the Family, Rev. ed., New York, Free Press, 1968.

*4. Bettelheim, Bruno, Children of the Dream, New York, Avon Books, 1969.

5. Buber, Martin, Paths in Utopia, Boston, Beacon Press, 1949.

6. Diamond, Stephen, What the Trees Said, Life on a New Age Farm, New York, Dell Publishing Co., 1971.

*7. Fairfield, Richard, Communes, U.S.A., Baltimore, Md., Penquin Books, 1972 .

8.

Alternatives Foundation, 1972 .

9. Farber, Seymour M. and Wilson, Roger, H.L., The Challenge to Women, New York, Basic Books, 1966.

10.' Flacks, Richard, Youth \& Social Change, Chicago, Markham Publishing. Co. , 1971 .

11. Goldberg, Steven, The Inevitability of Patriarchy, New York, Morrow, 1973 .

12. Gordon, Michael, ed., The Nuclear Family in Crisis: The Search for an Alternative, New York, Harper \& Row.

13. Gornick, Vivian \& Moran, Barbara K., eds., Woman in Sexist Society, New York, Basic Books, 1971.

14. Hedgepeth, William \& Stock, Dennis, The Alternative: Communal Life in New America, New York, MacMillan, 1970. 
15. Houriet, Robert, Getting Back Together, New York, Coward, McCann \& Geoghegan, Inc: , 1971 .

16. Howe, Louise Kapp, ed., The Future of the Family, New York, Simon \& Schuster, 1972 .

* 17. Kanter, Rosabeth Moss, Commitment and Community, Communes and Utopias in Sociological Perspective, Cambridge, Mass., Harvard University Press, 1972 .

18. ed., Communes, Creating and Managing the Collective Life, New York, Harper and Row, 1973.

19. Kaufman, Moritz, Utopias; or Schemes of Social Improvement, London, C. Kegan Paul and Co., 1879.

20. Keyes, Ralph, We the Lonely People: Searching for Community, New York, Harper and Row, 1973.

21. Kincade, Kathleen, A Walden Two Experiment: The First Five Years of Twin Oaks Community, New York, William Mlorrow and Co., Inc., 1972.

22. Lifton, Robert Jay, The Woman in America (The Daedalus Library), Boston, Houghton Mifflin Co., 1965.

23. Live it! Communalism, Canyon, Calif., 94516, Vocations for Social Change, 1971 .

24. Manahar Cooperative Fellowship Handbook, Sierra Route, Oakhurst, Calif., 93644, Broodan Center of Inquiry, 1970.

25. Manuel, Frank E., Utopias \& Utopian Thought (The Daedalus Library) Boston, Houghton Mifflin Co., 1966.

26. Marks, Paul J., A New Community - Format for Health, Contentment and Security, Questers' Project, Cathedral City, Calif., U.S.A.: Youth Resources, Inc...1969.

27. Melville, Keith, Communes in the Counter Culture, New York, Wm. Morrow and Co., Inc., 1972 .

28. Miller, Debbert, C., Handbook of Research Design and Social Measurement, second ed., New York, McKay, 1970 . 
29 Muncy, Ràymond Lee, Sex and Marriage in Utopian Communities, Baltimore, Penquin Books, 1974.

30. Nordhoff, Charles, The Communistic Societies of the United States, New York, Hillary House Publishing, Ltd., 1960 (originally published 1875) .

31. Noyes, John Humphrey, History of American Socialisms, New York, Hillary House, 1961 (originally published 1870) :

32. Noyes, Pierrepont, My Father's House: An Oneida Boyhood, New York, Farrar \& Rinehart, 1937.

33. Owen, Robert Dale, The Life of Robert Owen, By Himself, London, G. Bill, 1920 .

34. Rabin, A.I., Growing Up in the Kibbutz, New York, Sprịnger Publishing Co., 1965 .

35. Roberts, Ron E., The New Communes, Englewood-Cliffs, New Jersey, Prentice-Hall, Inc., 1971.

36. Robertson, Constance Noyes, Oneida Community: An Autobiography, 1851-1876, Syracuse, New York, Syracuse University Press, 1970.

37 . Oneida Community: The Breakup, 18761881, Syracuse, New York, Syracuse University Press, 1972 .

38. Rogers, Carl, Becoming Partners: Marriage \& Its Alternatives, New York, Dell Publishing Ço., 1972 .

39. Safilios - Rothschild, Constantina, ed., Toward a Sociology of Women, Lexington, Maine, Xerox College, 1972.

*40. Schur, Edwin M., ed., The Family and the Sexual Revolution, Bloomington, Ind., Indiana University Press, 1964.

41. Seward, Georgene, and Williamson, Robert C., eds., Sex Roles in a Changing Society, New York, Random, 1970.

42. Shaw', Marvin E. and Wright, J.M. , Scales for the Measurement of Attitudes, New York, McGraw-Hill, 1967. 
43. "Skinner, B.F. , Walden Two, New York, MacMillan, 1948.

44. Skolnick, Arlene S, and Jerome H., Family in Transition, Boston, Little Brown and Co., 1971.

45. Slater, Philip, The Pursuit of Loneliness, Boston, Beacon Press, 1970.

46. Weiss, Michael, Living Together: A Year in the Life of a City Commune, New York, McGraw-Hill, 1974.

*47. Weshues, Keith, Society's Shadow: Studies in the Sociology of Counter-Cultures, Toronto, McGraw-Hill Ryerson, Ltd., 1972.

48. Yablonsky, Lewis, The Hippie Trip, New York, Bobbs-Merrill Co., Inc., 1968.

49. Zablocki, Benjamin, The Joyful Community, Baltimore, Penquin Books, 1971 .

*Books marked contain extensive bibliographies.

\section{Articles}

50. Alpert, Jane, "Forum: Mother Right - A New Feminist Theory", Ms., vol. 2, no. 2, August, 1973, pp. 52-55, 88-94.

51. Angrist, Shirley S., "Role Conception as a Predictor of Adult Female Roles", Sociology and Social Research, vol. 50, no. 4, July, 1966 , pp. $448-459$.

52. Brown, I. Dave and Jane C., "The Struggle for an Alternative: A Case Study of a Commune", Human Organization, vol. 32, no. 3, Fall, 1973, pp. 257-66.

53. "Child Rearing in the Age of Aquarius", Human Behavior, vol. e, no. 2, May, 1974, p. 14.

54. Davis, Fred, "Why All of Us May Be Hippies One Day", Trans-action, vol. 5, no. 2, Dec., 1967 ; pp. 10-18.

55. Des Camp, Michael, Unpublished research paper on "extended families" in Portland, Ore., 1974. 
56. Flacks, Richard, "Young Intelligentsia in Revolt", Trans-Action, vol. 7 , no. 8, June, 1970, pp. 46-55.

57. I'oote, Nelson N., "New Roles for Men and Women", Marriage and Family Living, vol. 23, no. 4, Nov., 1961, pp. 325-29.

58. "Fourier, Charles", Encyclopaedia Britannica, 15th ed., vol. IV, pp. $254-255$.

59. Harder, Mary White et. al., "Jesus People", Psychology Today, vòl. 6, no. 7, Dec., 1972, pp. 45-50, 110-113.

60. Hochschild, Arlie Russell, "A Review of Sex Role Research", American Journal of Sociology, vol. 78, no. 4, Jan., 1972, pp. 1011-29.

61. Johnson, Mirium M., "Sex Role Learning in the Nuclear Family", Child Development, vol. 34, no. 2, June, 1963, pp. 319-33.

62. Jordan, June, "A Church Without Walls", Ms :, vol. 3, no. 2, Aug., 1974, p. 95 .

63. Kando, Thomas, "Role Strain: A Comparison of Màles, Females and Transsexuals", Journals of Marriage and the Family, vol. 34, no. 3, August, 1972, pp. 459-68.

64. Kanter, Rosabeth Moss, "Communes for All Reasons", Ms., vol. 3, no. 2, August, 1974, pp. 62-67.

65. Kanter, Rosabeth Moss, and Halter, Marilyn, "De-Housewifing Women, Domesticating Men: Changing Sex Roles in Urban Communes", unpublished paper presented at the American Psychological Association, Montreal, August, 1973.

66. Kincade, Kathleen, "A Walden Two Experiment", Psychology Today, vol. 6, no. 9, Feb., 1973, pp. 71-82.

67. Kopkind, Andrew, "The Way We Lived Then", (Review article - Weiss, Living Together) Ramparts, vol. 13, no. 3, October, 1974, pp. 51-53.

68. Komarovsky, Mirra, "Cultural Contradiction and Sex Roles: The Masculine Case", American Journal of Sociology, vol. 78, no. 4, Jan., 1973, pp. $873-84$. 
6.9. Mead, Margaret, "Beyond the Household",Dialogue, (U.S.I.S.); vol. 3, no. 4, 1.970 .

70. Minturn, Leigh, "Sex Role Differentiation in Contemporary Communes", unpublished paper.

71. Movement for a New Society, "New Society Packet", The Movement Building Collective, 4722 Baltimore Ave., Philadelphia, Pa. 19143 (no date) .

72. Oats, Marnie, "Twin Oaks", Women: A Journal of Liberation, vol. 2, no. 4,1972, pp. 28-30.

73. "Owen, Robert", Encyclopaedia Britannica, 15th ed., vol. VII, p. 643.

74. Papanek, Mirium L., "Authority and Sex Roles in the Family", Journal of Marriage and the Family, vol. 31, no. 1, Feb., 1969, pp. 88-96.

75. Perkins, Roberta Price, "Libre Rising", Ms., vol. 3, no. 2, August, 1974, p. 96.

76. Podell, L., "Sex and Role Conflict", Journal of Marriage and the Family, vol. 28, no. 2, May, 1966, pp. 163-65.

77. Pratt, Lois, "Conjugal Organization and Health", Journal of Marriage and the Family, vol. 34, no. 1, Feb., 1972, pp. 85-95.

78. Raymon, Paula, "The Commune Movement: The Need to Revolutionize", W.in, Dec. 6, 1973, pp. 8-9.

79. Roy, Beth, "Human Ecology", Ms., vol. 3, no. 2, Auǵ., 1974, p. 94.

80. Slater, Philip, "Cultures in Collision", Psychology Today, vol. 4, no.2, July, 1970, pp. 31-32, 66-68.

81. "Some Views From Women in Communes", Communities, no. 7, March April, 1974, pp. 11-13.

82. Trilling, Diana, "Culture, Biology and Sexual Roles", Dialogue, (U.S.I.S.) vol. 3, no". 4, 1970, pp. 11-19.

83. "Twin Oaks \& Little Folks", Communities, no. 9, July-August, 1974, pp. $10-12$. 
84. "Women in Community", Communities, no. 8., May - June, 1974, pp. 2-6.

85. Veysey, Lawrence, "Individualism Busts the Commune Boom", Psychology Today, vol. 8, no. 7, Dec., 1974, pp. 73-78. 
COMMUNE INFORMATION .

1. Community identifying number

2. Date started

3. Has community been in continuous existence since that date?

Yes

No

4. How many original members were there?

5. What is the largest number of members this commune has had?

The smallest?

6. How many members have left since formation?

7. How many new members have joined?

8. How many current members have been in residence six months or longer?

9. Number of current members?

Men?

Women?

Children under 14 ?

Ages and sexes?

Older children of commune adults?

Ages and sexes?

10. How many members are married?

11. How many members are in ongoing couple relationships?

12. Is this commune -

urban?

rural?

semi-rural? 
13. Is this commune?

a separate entity

part of a larger network of communes

and / or

receiving some direction from outside the

commune itself ( specify)

14. What are the criteria for belonging to this commune?

15. (If ideology is a factor) does this ideology provide a source of specific expectations regarding members' behavior?

Yes

No

(If yes) what are these expectations?

16. Is this commune interested in having new members ?

Yes

No

Depends on

17. Does the commune have a formal procedure for deciding whether a prospective member should come into the commune ?

Yes

No

(If yes) how is it done?

(If no) how is the decision made ? 
18. Where do couples live?

in separate houses or a partments in a single house

do they have a room

to themselves?

other (specify)

19. Where do single persons live?

in separate houses or apartments

in a single house do they have a room to themselves ?

other ( specify)

20. Are facilities for ........ cooking
a. separate by couple or family eating
b. separate for individual single persons bathing laundry
c. communal for single persons relaxing
d. communal for all
e. other ( specify)

21. Where do children sleep ?

in a special children's house

in a room near parent (s)

in parent (s) room

other ( specify)

(If they sleep in a special childrens' house) from what age ?

(If they sleep in a special childrens' house) who is responsible for them at night?

22. Do children eat separately from their parents ?

$$
\begin{aligned}
& \text { Yes } \\
& \text { No }
\end{aligned}
$$

(If yes) from what age ?

23. Who attended childbirth ?

woman goes to hospital physician for home delivery midwife for home delivery father for home delivery other adult member of commune who? other (specify) 
24. Does the commune own property ?

Yes

No

a. (If so) how was it obtained ?

as a gift

from members contributions

purchased by one member

purchased by one family

other ( specify)

b. (If so) how is the property held ?

in trust

as a corporation

by individual (s)

(if so) who?

other (specify)

c. (If so) is it completely paid for ?

Yes

No

(If not) how are payments made ?

d. If the commune were to disband how would property be disposed of ?

e. (If not) does the commune plan to own property if this is possible in the future?

Yes

No

25. How is commune money held ? by one person

who ?

by persons who earn/receive it

by a group with in the commune

other ( specify)

26. What kinds of income producing work are done by members of the commune ? men-how many?

women-how many?

farming

gardening

crafts

paid jobs in outside

community

what kinds

other ( specify)

none 
27. How is such work assigned or obtained?

28. How are specific financial needs of the commune met ? transportation

a. outside wages from members food

b. gifts from members

clothing

c. gifts from outsiders

housing needs

d. public assistance

e. sale of commune produced items

f. other ( specify)

recreation/cultural

education

medical

misc.

29. Does the entire commune ever get together to perform a common task such as painting the house, canning, etc.? Yes

No

( If yes) how often ?

(If yes) please specify tasks

30. Are required group meetings in which the entire commune gets together to discuss common concerns held? never

daily

weekly

biweekly:

monthly.

other ( specify)

31. What other types of group activities is this commune engaged in ?

About how often ?

Are any of these required for all? Yes

No

( If so) which ones?

32. Do childreri attend local public school ? Yes

No

( If yes) from what age ? 
33. Does the commune have any kind of school ?

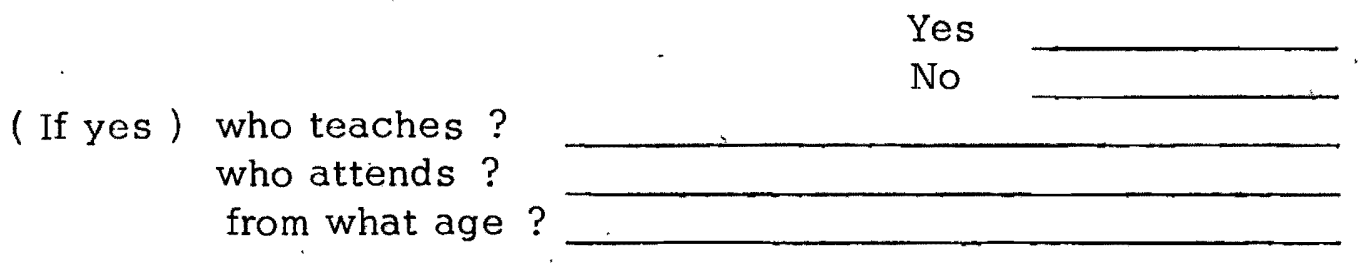

34. How does commune school differ from local public school ? in philosophy

in content

in method 


\section{RESPONDENT INFÓRMATION}

1. Community identification number

2. Respondent identification number

3. Personal information sex

age

religion

race

marital status*

children

(If yes) sex ages

4. Liducational level attained 8th grade or less

high school

some college

college completed

some grad. study

specialized training

or school

in what?

completed grad. study

in what field?

5. What were your occupation(s) prior to joining the commune?

6. What is your present occupation?

7. Did you grow up primarily in an urban area, rural area or small town? urban rural

small town

8. What is your understanding of the primary reason(s) for the formation of this commune?

* Note if spouse is resident or non-resident. If resident and participating, qive respondent number. 
9. What are the primary reasons that you personally joined this commune?

10. Have you lived in other communes prior to this one? Yes

(If so) how many? how long?

11. What do you think some of the reasons are that people leave communes?

12. As you see your present situation, how long do you plan to remain in this commune?

(If planning to move soon) would you mind sharing what leads you to consider moving?

\section{INTRODUCTION}

13. Were sex roles discussed during formation of this commune?

(If yes) generally what did the discussions consist of?

Yes

No 
13 (con't.).

(If there is an acknowledged ideology) did ideology play any part in the discussion?

Yes

No

(If yes) in what ways?

(If yes) were the discussions -

extensive?

limited?

in between?

(If yes) did you come to any agreements?

Yes

(If yes) what were they?

No

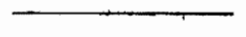

(If yes) were there any major disagreements?

Yes

(If yes) what were they?

No

How frequently are similar issues discussed in ongoing meetings? very often fairly often occasionally rarely never

(If so) what specific issues are raised? 
14. Do you see communes as potentially having a unique influence in the development of the roles of men and women in our society?

Yes

No

Could you share your thinking on this?

15. Did you enter this commune expecting differences in sex roles from what is generally found in the traditional nuclear family?

Yes

No

(If yes) what kinds of differences?

16. Has this commune specifically discussed the socialization of its children regarding sex roles?

Yes

Have you come to any agreements?

No

Yes

No

(If so) what are they?

Have there been any major disagreements?

Yes

No

(If so) what? 
17. If you could design the ideal arrangement of roles of men and women, what things would seem most important to you?

Could you order them in degree of importance?

18. At points where you are involved with the larger society (such as outside jobs, etc.) do you see any differences in the expectations of you as a man/woman?

Yes

No

(If so) what differences do you see?

How do you handle these differences?

19. At points where commune children are involved with the larger society, do they come up against standards and values different from those they have learned in the commune?

Yes

No

(If yes) what kinds of differences are involved?

Do you see any of these differences as related to sex role expectations? Yes

No 
19. (cont.)

How do children respond to these differences?

In what ways do adults participate with children in resolving the differences ?

19a (If has a child) where does financial contribution for child (children) come from ?

If both parents are resident in the commune

from both parents

from one parent (which ?)

from entire commune

other ( specify)

If one parent is resident in the commune (may have more than one answer)

from resident parent

from nonresident parent

from both parents

from parents' present partner

from entire commune

other ( specify)

20. With whom does major responsibility rest for the care of children under two years?

mother

father

both parents

other adults

who?

21. With whom does major responsibility rest for the care of children from two - school age?

mother

father

both parents

other adults

who ? 
22. With whom does major responsibility rest for the care of children from school age - 12 years ?. mother

father both parents other adults who ?

23. What responsibilities do children over 12 have ?

24. What decisions do children make for themselves ? boys

girls 2 - school age

school age -12

over 12

25. If a child's behavior causes some difficulty for the group how is the situation dealt with ?

Who is involved in the process?

26. Have your ideals regarding sex role differenttation changed any as a result of communal living ?

Yes

No 
26. (cont.)

(If yes) would you be willing to identify what the changes are ?

(If yes) what do you think led to this change?

27. To what extent do you feel this commune reaches the ideal arrangement you outlined earlier regarding roles of men and women ?

$\begin{array}{lllll}1 & 2 & 3 & 4 & 5 \\ \text { not at all } & & & \text { very much }\end{array}$

Could you share what leads you to feel this way?

28. (If decisions were made) how satisfied are you, on the whole, with decisions that have been made by this community regarding roles of men and women?

$\begin{array}{lllll}1 & 2 & 3 & 4 & 5 \\ \begin{array}{c}\text { very } \\ \text { dissatisfied }\end{array} & & & \begin{array}{c}\text { very } \\ \text { satisfied }\end{array}\end{array}$

Could you share what your major satisfactions and dissatisfactions are? 
(If decisions were made)

29. How satisfied are you, on the whole, with decisions that have been made by this community concerning socialization of children regarding sex roles ?

$\begin{array}{ccccc}1 & 2 & 3 & 4 & 5 \\ \begin{array}{c}\text { very } \\ \text { dissatisfied }\end{array} & & & \begin{array}{c}\text { very } \\ \text { satisfied }\end{array}\end{array}$

Could you share what your major satisfactions and dissatisfactions are ?

30. (If decisions were made) to what extent do you feel group decisions regarding roles of men and women have actually become reality in this commune?

not $\begin{array}{lllll}1 & 2 & 3 & 4 & 5 \\ \text { at all } & & & \text { very much }\end{array}$

Could you share how you feel this has come about?

31. (If decisions were made) to what extent do you feel group decisions made concerning socialization of children regarding sex roles have actually become reality in this commune?

$\begin{array}{lllll}1 & 2 & 3 & 4 & 5 \\ \text { not at all } & & & & \text { very much }\end{array}$

Could you share how you feel this has come about? 
32. (If no decisions wore made) how satisfied are you, on the whole, with the development of roles of men and women in this community ?

$\begin{array}{ccccc}1 & 2 & 3 & 4 & 5 \\ \text { very } & & & & \begin{array}{c}\text { very } \\ \text { satisfied }\end{array}\end{array}$

Could you share what your major satisfactions and dissatisfactions are ?

33. (If no decisions were made) how satisfied are you, on the whole, with the way in which socialization of children regarding sex roles has developed in this community?

$\begin{array}{ccccc}1 & 2 & 3 & 4 & 5 \\ \text { very } & & & & \begin{array}{c}\text { very } \\ \text { satisfied }\end{array}\end{array}$

Could you share what your major satisfactions and dissatisfactions are ? 
In this commune who ?

\begin{tabular}{|c|c|c|c|}
\hline Activity & Who & $\begin{array}{l}\text { Method of } \\
\text { assignment }\end{array}$ & $\begin{array}{l}\text { Any change over } \\
\text { time? when? reasons? }\end{array}$ \\
\hline \multicolumn{4}{|l|}{ washes clothes } \\
\hline \multicolumn{4}{|c|}{ repairs and maintains the house } \\
\hline \multicolumn{4}{|c|}{ does light cleaning } \\
\hline \multicolumn{4}{|l|}{ reads to children } \\
\hline \multicolumn{4}{|l|}{ plans meals } \\
\hline \multicolumn{4}{|l|}{ cares for sick children } \\
\hline \multicolumn{4}{|c|}{ speak for group to out siders } \\
\hline \multicolumn{4}{|c|}{$\begin{array}{l}\text { makes decisions on how money } \\
\text { will be spent }\end{array}$} \\
\hline \multicolumn{4}{|c|}{ Calls group meetings } \\
\hline \multicolumn{4}{|l|}{ cares for livestock } \\
\hline \multirow{2}{*}{\multicolumn{4}{|c|}{ washes dishes }} \\
\hline & & & \\
\hline \multicolumn{4}{|c|}{ gardens } \\
\hline \multicolumn{4}{|c|}{ prepares food for canning, freezing } \\
\hline \multicolumn{4}{|c|}{ cans food } \\
\hline \multicolumn{4}{|l|}{ keeps motor vehicles running } \\
\hline \multicolumn{4}{|l|}{ puts children to bed } \\
\hline \multicolumn{4}{|l|}{ changes diapers } \\
\hline \multicolumn{4}{|l|}{ washes diapers } \\
\hline \multicolumn{4}{|l|}{ pays bills } \\
\hline \multicolumn{4}{|l|}{ does heavy cleaning } \\
\hline \multicolumn{4}{|l|}{ disciplines children } \\
\hline \multicolumn{4}{|l|}{$\begin{array}{l}\text { plays with children } \\
\text { dresses children }\end{array}$} \\
\hline & & & \\
\hline \multicolumn{4}{|l|}{ buys groceries } \\
\hline \multicolumn{4}{|l|}{ farms } \\
\hline \multicolumn{4}{|l|}{ hunts } \\
\hline \multicolumn{4}{|l|}{ fishes } \\
\hline \multicolumn{4}{|l|}{ deals with neighbors } \\
\hline \multicolumn{4}{|l|}{ plans social activities } \\
\hline \multicolumn{4}{|l|}{ decides on who may join } \\
\hline decides on who may visit & & & \\
\hline
\end{tabular}

Could you summarize briefly either specific or general activities which you you never or rarely did before joining the commune but do now ? [ use back]

WHO

a. entirely up to men ( a man)

b. entirely up to women ( $a$ woman)

c. mostly up to men ( a man)

d. mostly up to women (a woman)

e. done by men and women equally

f. done by others outside the commune

g. no one

h. not applicable
METHOD OF ASSIGNMENT

(more than one may be applicable)

1. whoever is available

2 . by regular rotation among all members

3 . by regular rotation among some members who ?

4. on permanent or long-term basis

5 . by individual interest and/or skill

6 . by lot

7. by assignment from one person - who?

8. by assignment from small group - who?

o nthar $($ anonifur $)$ 


\section{APPENDIX B}

\section{COMMUNE INFORMATION}

It may be helpful to read the entire questionnaire before beginning. If there are some questions that are not applicable to your situation, skip them.

1. Community identifying number

2. Date started

3. Has community been in continuous existence since that date?

Yes

No

4. How many original members were there?

5. How many members (original members and/or later joiners) have left?

6. How many new members have joined since formation?

7. How many current members have been in residence six months or longer?

8. Number of current members?
a. Men?
b. Women?
c. Children under 14?
d. Ages and sexes?
e. Older children of commune adults?
f. Ages and sexes?

9. How many members are in ongoing couple relationships?

a. Of these, how many are legally married?

10. Is this commune - ?

urban

rural

semi-rural 
11. Is this commune - ?

$$
\text { a separate entity }
$$

part of a larger network of communes and/or receiving some direction from outside the commune itself (specify)

12. What are the criteria for belonging to this commune?

13. Is this commune interested in having new members?

Yes

No

Depends on

14. Where do couples live?

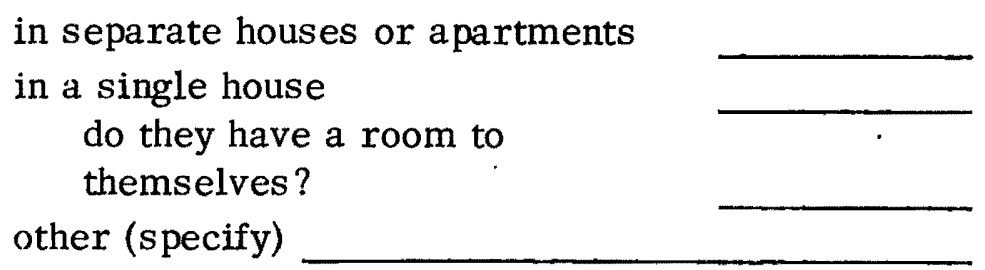

15. Where do single persons live?

in separate houses or apartments

in a single house

do they have a room to

themselves?

other (specify)

(May have more than one answer from list on left)

16. Are facilities for. ......... cooking

a. separate by couple or family eating

b. separate for individual single persons

c. communal for single persons

d. communal for all

e. other (specify) bathing laundry relaxing 
17. Where do children sleep?

in a special childrens' house

in a room near parent(s)

in parent(s) room

other (specify)

a. If they sleep in a special childrens' house, from what age?

b. If children sleep in a special childrens' house, who is responsible for them at night?

(May check more than one answer)

both parents

mother

father

all adults by rotation

adults by proximity

older children

no one

other (specify)

18. Have any children been born to members since formation of this commune?

Yes

No

a. If yes, how many?

b. If yes, who attended childbirth?

(May check more than one answer)

woman goes to hospital

physician for home delivery

midwife for home delivery

father for home delivery

other adult member of commune

who?

other (specify)

19. Does the commune own property?

Yes

a. If yes, how was it obtained?

No

as a gift

from members contributions

purchased by one member

purchased by one family

other (specify) 
19 (con't.)

b. If yes, how is the property held?

in trust

as a corporation

by individual(s)

who?

jointly by all adults

other (specify)

c. If the commune owns property, how would property be disposed of if the commune were to disband?

sold \& proceeds distributed equally

haven't decided

donated to non-profit organization

shares sold to one or more members

other (specify)

d. If the commune does not own property, does it plan to own property if this is possible in the future?

Yes

No

20. Are financial contributions for support of the commune made - ? equally by all members

by ability to pay

other (specify)

21. Are certain perșons exempt from financial contributions?

Yes

No

a. If yes, who and on what basis?

22. What kinds of income producing work are ordinarily done by members of \begin{tabular}{l|l|l} 
the commune? & men - how many? & women - how many?
\end{tabular}

\begin{tabular}{|l|l|l|}
\hline paid jobs in outside community & & \\
\hline what kinds? & & \\
\hline farming & & \\
\hline gardening & & \\
\hline crafts & & \\
\hline
\end{tabular}


23. Docs the entirc commune ever get together to perform a common task? Yes

No

a. If yes, how olten?

b. If yes, please specify tasks?

24. Are group meetings in which the entire commune gets together to discuss common concerns held?

never
daily
weekly
biweekly
monthly
other (specify)

a. Is attendance generally expected?

Yes

No

b. If this pattern has changed since formation of the commune, how and why?

25. Do children attend local public school?

Yes

No

a. If yes, from what age?

26. Does the commune have any kind of school?

Yes

No

a. If yes, who teaches?

b. who attends?

c. from what age?

27. How does commune school differ from local public school?

a. in philosophy 
27 (con't.)

b. in content

c. in method 


\section{RESPONDENT INFORMATION}

It may be helpful to read the entire questionnaire before beginning. There will undoubtedly be some questions that are not applicable to your situation. Skip them.

1. Community identification number

2. Respondent identification number

3. Personal information

a. sex

c. Do you have children?

b. age

1) If yes, males (ages?)

2) females (ages?)

d. Are you in an ongoing couple relationship?

1) If yes, is your partner resident in commune?

Yes

No

2) If yes, partner's respondent number

Yes

No

2) If yes, parther's respondent number

4. Educational level attained?

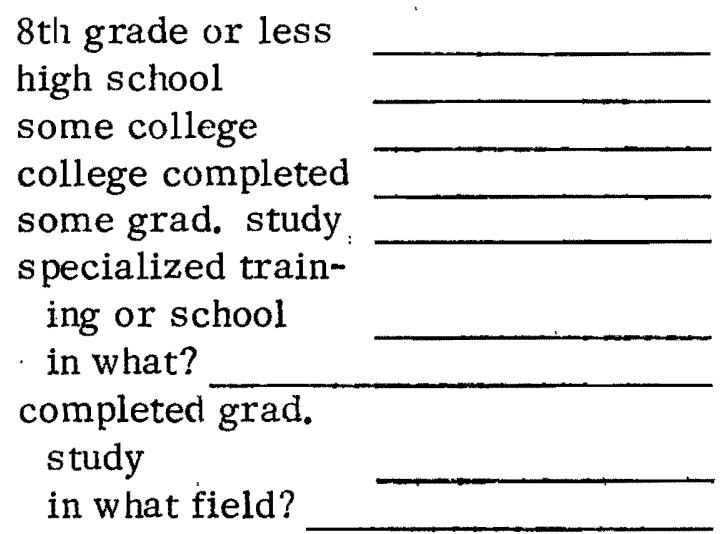

5. What were your occupation(s) prior to joining the commune?

6. What is your present occupation?

7. What is your understanding of the primary reason(s) for the formation of this commune? 
8. What are the primary reasons that you personally joined this commune?

9. How long have you lived in this commune?

10. Have you lived in other communes prior to this one? Yes
a. If yes, how many?
b. how long?

11. What do you think some of the reasons are that people leave communes?

12. As you see your present situation, how long do you plan to remain in this commune?

INTRODUCTION: The following questions focus on how roles of men and women and socialization of children related to sex roles have developed in this community.

When we refer to sex roles in the questions we mean those patterns of behavior or expectations for behavior, those specific rights and duties that are accorded an individual on the basis of what sex he or she is.

As you know, sex roles are being increasingly discussed and questioned in our society. We believe that there are many valid alternatives for individuals or groups in developing patterns of sex roles appropriate for themselves.

Communes are, of course, one form of intimate social organization in which sex roles, in some form, will be expressed. We are eager to gain some appreciation of how various communes are dealing with this area. 
13. If you have been a member since formation, please answer these : questions -

a. Were sex roles discussed during the formative period?

Yes

No

b. If yes, what specific issues were raised and what specific decisions were made?

c. How frequently are similar issues discussed in ongoing group meetings? very often fairly often occasionally rarely never

d. What specific issues are raised and what new decisions have been made?

14. If you have joined the commune after formation, please answer these questions -

a. How frequently have sex roles been discussed in ongoing group meetings? very often fairly often occasionally rarely never 
b. What specific issues are raised and what specific decisions have been made?

15. If decisions have been made (Questions $13 \& 14$ ) -

a. How satisfied are you, on the whole, with the decisions that have been made by this community regarding roles of men and women?

$\begin{array}{ccccc}1 & 2 & 3 & 4 & 5 \\ \begin{array}{c}\text { very } \\ \text { dissatisfied }\end{array} & & & & \begin{array}{c}\text { very } \\ \text { satisfied }\end{array}\end{array}$

b. Could you share what your major satisfactions and dissatisfactions are?

c. To what extent do you feel group decisions regarding roles of women and men have actually become reality in this commune?

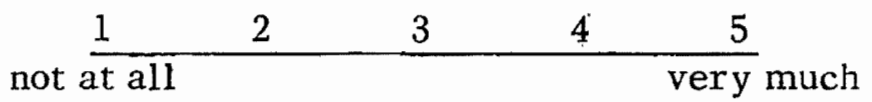

d. What factors have aided this process?

e. What factors have hindered this process? 
16. If no decisions have been made (Questions $13 \& 14$ ) -

a. How satisfied are you, on the whole, with the development of roles of men and women in this community?

$\begin{array}{ccccc}\frac{1}{\text { very }} & 2 & 3 & 4 & 5 \\ \text { disśatisfied } & & & & \begin{array}{c}\text { very } \\ \text { satisfied }\end{array}\end{array}$

b. Could you share what your major satisfactions and dissatisfactions are?

17. Do you see communes as potentially having a unique influence in the development of the roles of women and men in the larger society?

Yes

No

a. If yes, how?

b. If no, why not?

18. Did you enter this commune expecting differences in sex roles from what is generally found in the traditional nuclear family?

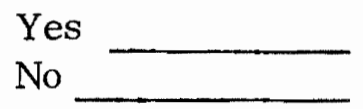

a. If yes, what kinds of differences? 
19. When sex role expectations of the larger society conflict with roles valued within the commune, how do you respond to these conflicts?

20. Have your ideals regarding sex roles changed any as a result of communal living? Yes

No

a. If yes, would you be willing to identify what the changes are?

b. If yes, what do you think led to this change? 
21. In this commune, who - ? (MORE TILAN ONI ANSWER MAY Bli APPLICABLE) CHOOSE ANSWERS FROM LISTS FOLLOWING CHART activity who method of assignment

\begin{tabular}{|l|l|l|}
\hline clepairs the house & & \\
\hline plans meals & & \\
\hline cares for sick children & & \\
\hline speaks for group to outsiders & & \\
\hline $\begin{array}{l}\text { makes decisions on how com- } \\
\text { calls group meetings }\end{array}$ & & \\
\hline cares for livestock & & \\
\hline washes dishes & & \\
\hline decides on who may join & & \\
\hline cooks & & \\
\hline gardens & & \\
\hline $\begin{array}{l}\text { prepares food for canning, } \\
\text { freezing }\end{array}$ & & \\
\hline keeps motor vehicles running & & \\
\hline changes diapers & & \\
\hline pays bills & & \\
\hline buys groceries & & \\
\hline farms & & \\
\hline puts children to bed & & \\
\hline holds and distributes communal & & \\
money & & \\
\hline
\end{tabular}

WHO

a. entirely done by men (a man)

b. mostly done by men (a man)

c. entirely done by women (a woman)

d. mostly done by women (a woman)

e. done by men and women equally

f. done by both parents equally

g. done mostly by mothers

h. done mostly by fathers

i. not applicable

j. other (specify)

k. no response

1. uncodable response 
21. (con't.) METHOD OF ASSIGNMENT

1. whoever is available (volunteer)

2. by individual interest and/or skill

3 . by sign up sheet

4. by regular rotation among all members

5 . by regular rotation among some members, who?

6. by assignment from one person, who?

7. by assignment from small group, who?

8. on permanent or long-term basis

9. by lot

10. other (specify)

22. Has the pattern of responsibility for any of the activities on the preceding page changed over time?

Yes

a. If yes, how and why?

No

a. If yes, how and why?

23. Could you summarize briefly either general or specific activities which you never or rarely did before joining the commune, but do now?

If this commune has children, please answer the rest of the questionnaire.

24. Has this commune specifically discussed the socialization of its children regarding sex roles?

Yes

No

25. How satisfied are you on the whole, with the way in which socialization of children regarding sex roles has developed in this commune?

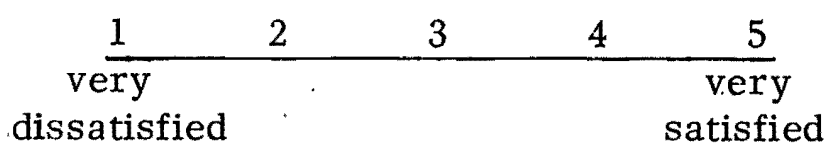


a. Could you share what your major satisfactions and dissatisfactions are?

26. At points where commune children are involved with the larger society, do they come up against standards and values regarding sex roles which are different from those they have learned in the commune ?

Yes

No

a. If yes, what kinds of differences are involved ?

b." If yes, how do children respond to these differences ?

27. If you are a parent and your child is resident, with whom does responsibility for care and for financial support rest ?

\begin{tabular}{|l|l|l|l|l|}
\hline both parents equally & under 2 & & & \\
\hline mother & & & & \\
\hline father & & & & \\
\hline entire commune & & & & \\
\hline non-resident parent & & & & \\
\hline resident parent's partner & & & & \\
\hline other (specify) & & & & \\
\hline
\end{tabular}


28. Do you see the disciplining of children as a communal or parental function ? communal parental

29. Who actually disciplines children ?

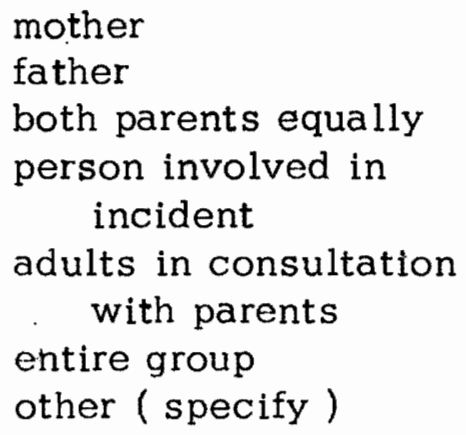

30. Do you think that disciplining of children is fairly consistent ?

Yes

No 


\section{APPENDIX C \\ INTRODUCTION OF RESEARCH TO GROUPS}

[ Notes for introduction of ourselves and the research material - for personal use or in letters requesting permission to visit and survey]

In taking on this project we realize we are asking a good deal of members of communes. We are strangers, and we are asking people to allow us into the privacy of their homes and lives. As you can imagine, we have a lot of scared feelings ourselves about doing this. We really would never have the nerve to consider asking commune members to so share themselves and to give the time involved if we did not genuinely feel that what we hope to experience and learn as persons and as social workers would make us better able to be helpful to other persons with whom we may work.

Both of us are personally and professionally committed to an effort to understand as many as possible of the options in life styles available to people in our current messed up society. We recognize there are all kinds of significant factors in communal life that could be considered. Our biggest problem has been to curb our enthusiasm and recognize the limitations of time and our student condition. We've focus ed on sex roles mainly because we know how urgent this concern is for many people right now and because we see this factor as having possible implications for other aspects of family and general social life. We recognize an element of bias in two women working on this subject . 
There are a few specific areas which we'd like to clarify .

1. Commune members would be free not to answer specific questions which they might prefer not to. It would be up to them whether or not to offer reasons for such a preference:

2. Responses would be held both confidential and anonymous . It would not even be necessary for members to identify themselves by name if they prefer not to.

3. We would be very happy to share the results - whatever we end up with - to whatever degree participants would find it useful or interesting .

4. We are very open to questions or suggestions. We realize there may well be areas of relevant facts or feelings which we have missed in preparing these questions. This is another part of what we want to learn.

5. The questionnaire is long, and we're open as to how it can best be handled practically. We can meet with individuals at their convenience or can sit down with a group. We'd like each group to say how they would feel most comfortable. We would like to be present when answers are being given, in case of questions and also to provide some similarity in collecting of information from various groups.

We are very excited by the reading we have been doing about communal life and by the persons with whom we have already talked. We know we are amateurs in research and that we are very dependent on the patience 
and good humor of those who are willing to help us in this task. We look forward to growth as persons and in our work through this experience, and most especially through the persons whom we hope to meet. 


\section{APPENDIX D}

\section{LIST OF VARIABLES}

Information related to individual respondents

Age

Sex

Children

Couple relationship

Educational level

Occupation

Perceptions of reason for formation

Personal reasons for joining

Length of time in household

Prior similar experience

Perceptions of reasons for leaving

Intent to remain

Discussion of sex roles during formative period

Frequency of ongoing discussion of sex roles

Satisfaction with decisions

Satisfaction with development of roles

Perception of decisions becoming reality

Perception of potential unique influence

Expected differences in sex roles from nuclear family

Response to conflicts with society over sex roles

Change in sex role ideals

Perception of actual task division and methods of assignment

Change in task division

New activities undertaken

Information related to cooperative households

Duration of household

Continuity of household

Original size

Changes in membership

Composition of membership

Couple relationships

Urban-rural designation

Connectional status

Membèrship criteria

Openness to new members

Living arrangements and facilities

Ownership of property

Financial support of household

Income producing work

Performance of common tasks

Hous ehold meetings 


\section{APPENDIX E \\ 1 \\ CODING CATEGORIES}

Original categories

Commune information

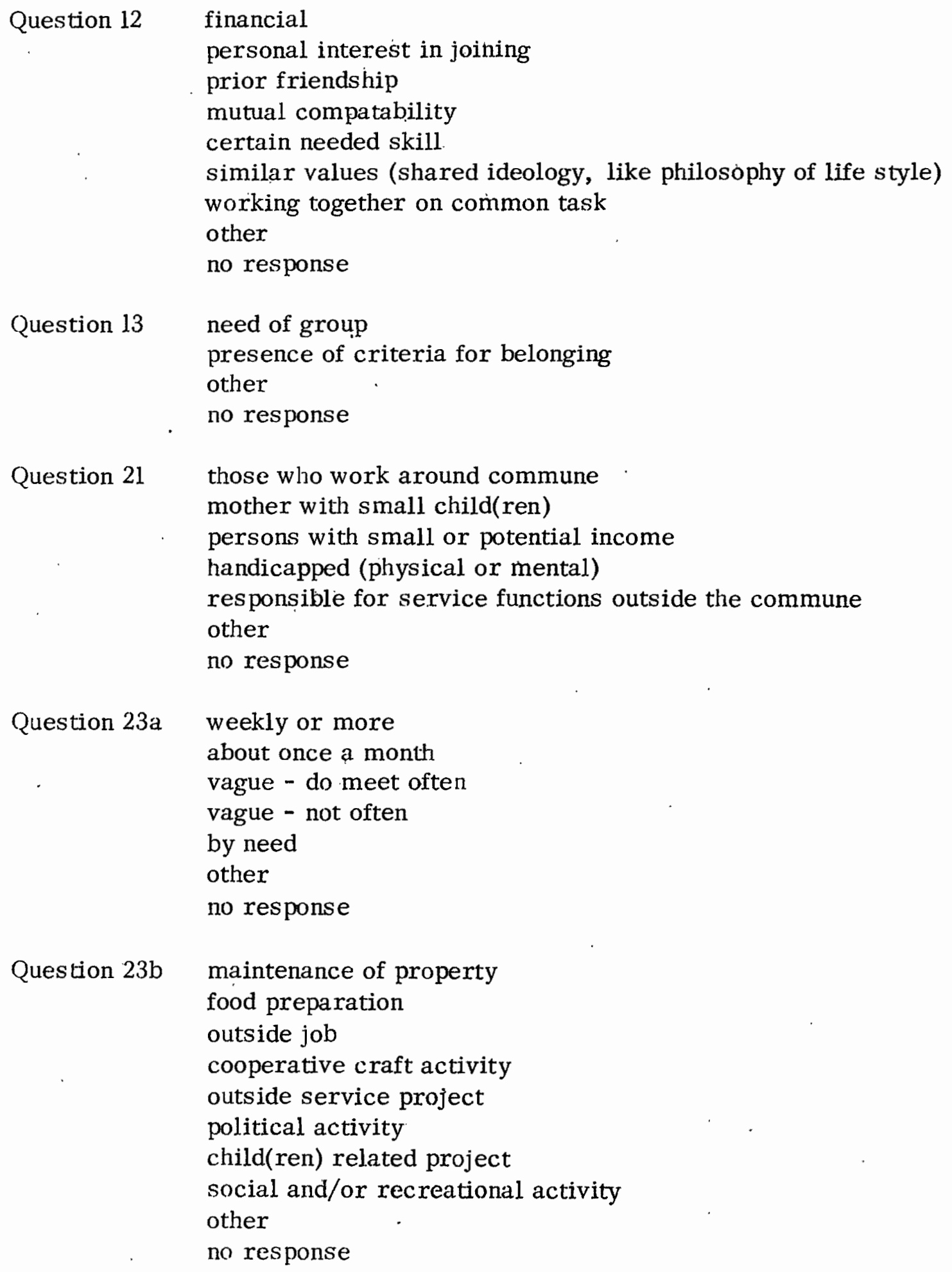




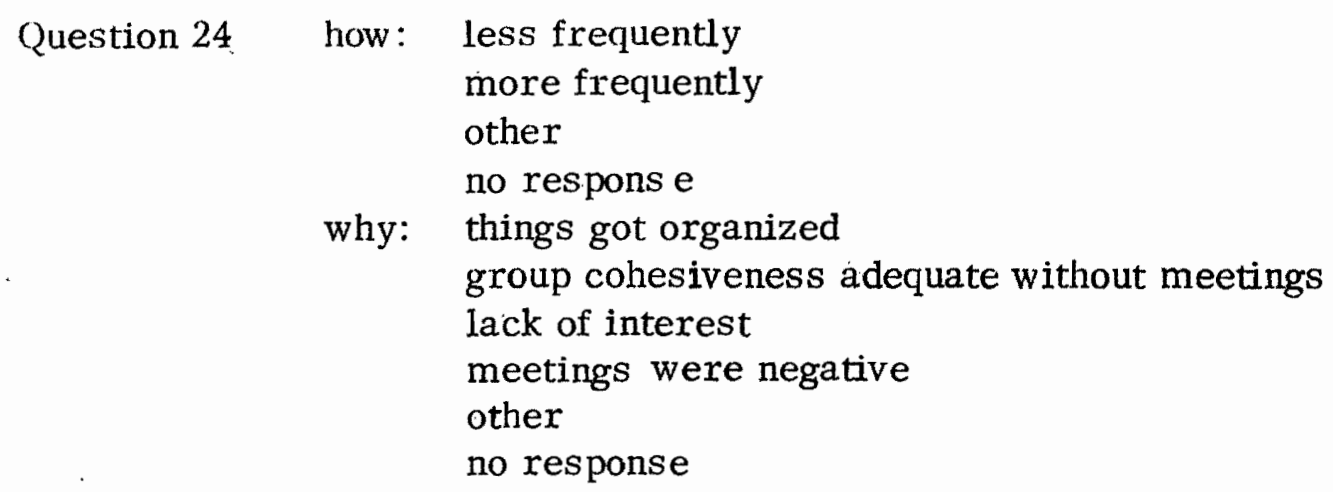

Question 26

parents

mothers

fathers

other commune adults

outside teachers

older children

other

no response

Question 27 not coded - responses to be used for observations

Respondent information

Question $7 \quad$ values

personal grow th

growth in relationships

emational support from group:

ecology

good for children

good for parent rearing child(ren)

economics

escape

as an experiment

living close to land

lessening household burdens

other

no response

Question $8 \quad$ all of categories for no. 7 plus

a personal relationship

adventure

Question $11 \quad$ personal conflicts

difference in philosophy

intensity of encounters 
Question 11 (con't.)

need for more personal control

unsuccessful couple relationship

differences over child rearing

changing goals

external circumstances

lack of commitment to group

desire for more contact with outside world

illness

can't adapt to a new life style

disappointment in expectations

other

no response

Question 13b \& 13d

issues: household responsibilities

parenting

employment

women learn to do traditional male skills and chores

emotional roles

observation of existing sex roles

other

no response

(note: above may be given in various combinations)

decisions: to avoid standardized stereotyped roles

to learn to employ opposite sex role

to start consciousness raising groups

to reinforce standard roles

to play it by ear

other

no response

Question 14b same as question 13b

Question 15b same as question $13 b$

Question 15d ideology

commitment

interpersonal support

specific awareness training

group expectations

strong leadership

other

no response

Question 15e previous life experience

social pressure 
Question 15e (con't.)

social structure

lack of communication

internal differences of opinion

internal pràctical difficulties

other

no response

Question 16b same as question $13 b$

Question $17 \mathrm{a}$ yes, how? as a model

personal influence

children who grow up in communal setting

other

no response

Question $17 \mathrm{~b}$ no, why not ?too small

change doesn't occur that fast

lack of power

lack of unity

other

no response

Question 18a same as question $13 b$

Question 19 aggressive - positive

aggressive - negative

passive - withdrawal (avoidance)

passive - acceptance

other

no response

Question 20a more equalitarian

ideal has become more realistic

increased personal comfort with more equal roles

less equalitarian

other

no response

Question 20b same as question $15 d$

Question 22a how? more differentiated by male and female less differentiated by male and female other

no response 
Question $22 \mathrm{a}$ (con't.) why?

changing needs of commune changing philosophy of commune practical considerations other no response

Question 23 same as question 22a, how section.

Question 25a . presence of models absence of models differences among adults re standards reversion to patterns of upbringing of adults inability of communal experience to prepare children to maintain standards outside

other

no response

$\begin{array}{ll}\text { Question 26a } & \text { dress } \\ & \text { hygiene } \\ & \text { tasks } \\ & \text { occupational emphasis } \\ & \text { text books }\end{array}$

Question 26b same as question 19

Revisions in categories

Commune information

$\begin{array}{lll}\text { Question } 12 & \begin{array}{l}\text { addition } \\ \text { clarification }\end{array} & \begin{array}{l}\text { decision of group } \\ \text { working together on common task is internal }\end{array} \\ \text { Question } 13 & \begin{array}{l}\text { addition } \\ \text { change }\end{array} & \begin{array}{l}\text { availability of space } \\ \text { need of group to usefulness to group }\end{array} \\ \text { Question 2.3b } & \text { change } & \begin{array}{l}\text { maintenance of property to building } \\ \text { and maintenance }\end{array}\end{array}$

\section{Respondent information}

Question 5

categories were delineated later as they were seen as fairly standarized categories as follows:

proprietors, owners, managers 
Question 5 (con't.)

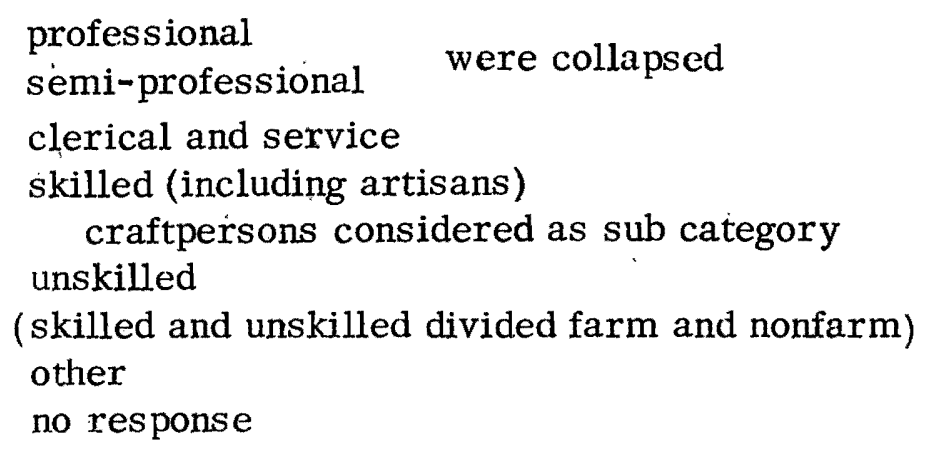

Question $7 \quad$ change

$$
\text { clarification values are conscious and deliberate }
$$

Question $8 \quad$ same as question 7

\begin{tabular}{|c|c|c|}
\hline Question 11 & $\begin{array}{l}\text { change } \\
\text { addition } \\
\text { change } \\
\text { clarification } \\
\text { addition }\end{array}$ & $\begin{array}{l}\text { personal conflicts to interpersonal conflicts } \\
\text { need for more privacy } \\
\text { lack of commitment to lack of commitment to } \\
\text { group } \\
\text { changing goals are personal goals } \\
\text { dissatisfied with expectations }\end{array}$ \\
\hline Question 13b & $\begin{array}{l}\text { issues: } \\
\text { addition } \\
\text { addition } \\
\text { change } \\
\text { decisions: } \\
\text { change }\end{array}$ & $\begin{array}{l}\text { general roles } \\
\text { issue not listed } \\
\text { collapse observations into other categories } \\
+-0 \quad \text { (the key for symbol definition } \\
\text { is given with each table where used) } \\
\text { decision not listed }\end{array}$ \\
\hline
\end{tabular}

Question 14b same as question 13b

Question $15 \mathrm{~b}$ change satisfactions and dissatisfactions were merely differentiated rather than coded

Question 16b same as question 15b

Question 15d addition. commonality of group members addition personal growth and maturation change group expectations to group expectations and agreement 


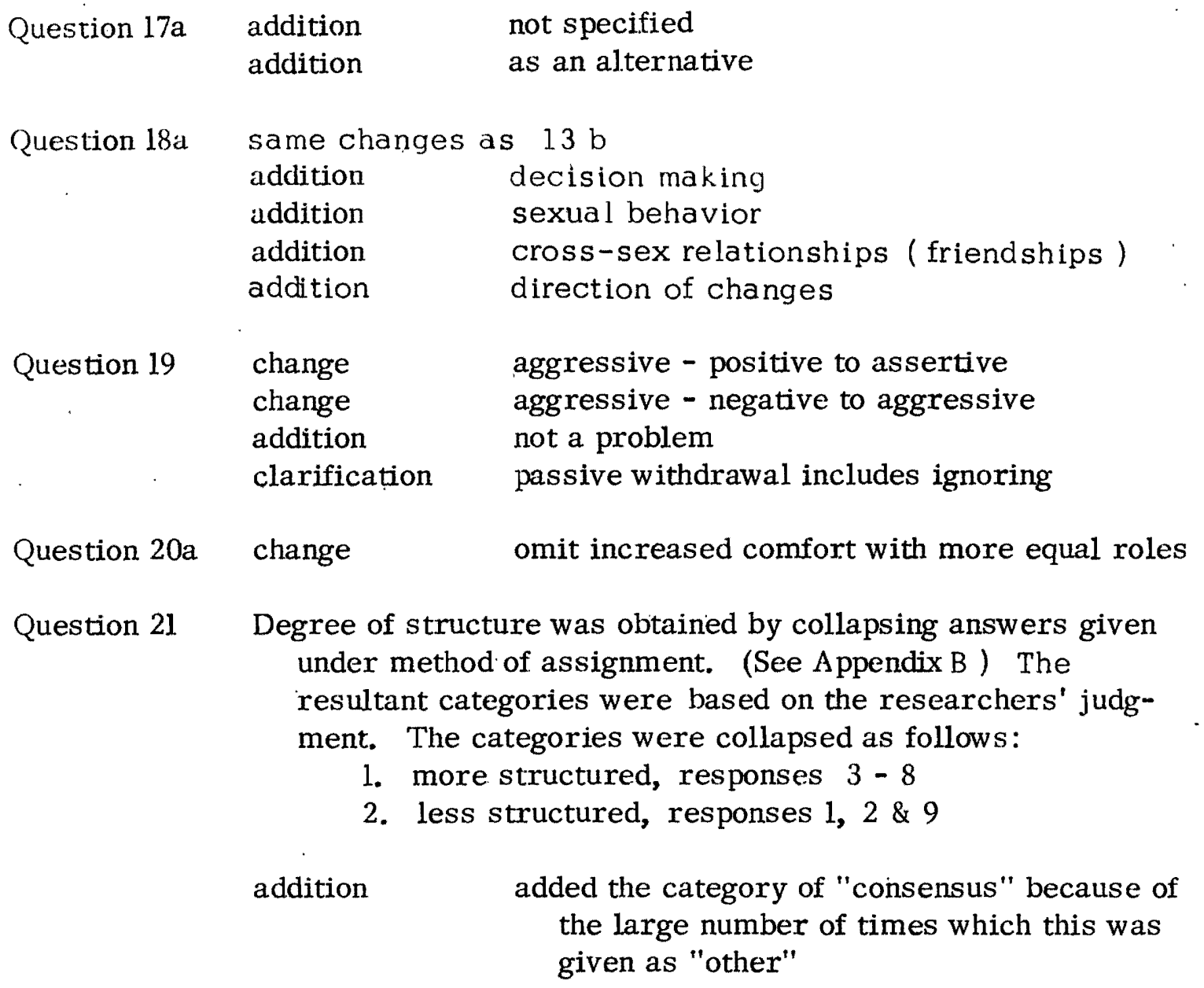

Question 22a how:

change to +0 - (the key for symbol definition is given for each table where used)

addition couldn't get cooperation

addition individual preferences

clarification practical considerations includes skills why:

addition group consciousn ess 
APPENDIX F

TABLES

TABLE 1

NUMBER OF MONTHS COMMUNE HAD BEEN IN EXISTENCE AS OF SEPTEMBER 1974

\begin{tabular}{|} 
Number of Months \\
\hline $0-6$ & 2 & 0 & Total \\
\hline $7-12$ & 0 & 0 & 2 \\
\hline $13-18$ & 3 & 2 & 0 \\
\hline $19-24$ & 3 & 0 & 5 \\
\hline $25-30$ & 2 & 1 & 3 \\
\hline $31-36$ & 2 & 0 & 3 \\
\hline $37-42$ & 0 & 2 & 2 \\
\hline $43-48$ & 0 & 0 & 0 \\
\hline 49 & 0 & 0 & 19 \\
\hline 55 & 13 & 0 & 1 \\
\hline 7 Years & 0 & 0 & 1 \\
\hline
\end{tabular}

TABLE 2

WHETHER OR NOT COMMUNE HAS BEEN IN CONTINUOUS EXISTENCE SINCE FOUNDED

Whether or Not

Urban

Rural

Total

\begin{tabular}{|l|c|c|c|}
\hline Yes & 13 & 6 & 19 \\
\hline No & 0 & 0 & 0 \\
\hline Total & 13 & 6 & $19 \mathrm{~N}$ \\
\hline
\end{tabular}


TABLE 3

NUMBER OF ORIGINAL MEMBERS

\begin{tabular}{|c|c|c|c|}
\hline Number of Original Members & Urban & Rural & Total \\
\hline $0-5$ & 6 & 2 & 8 \\
\hline $6-10$ & 5 & 2 & 7 \\
\hline $11-15$ & 1 & 2 & 3 \\
\hline No Response & 1 & 0 & 1 \\
\hline Total & & & $19 \mathrm{~N}$ \\
\hline
\end{tabular}

TABLE 4

NUMBER OF ORIGINAL MEMBERS AND $/ O R$ LATER JOINERS WHO HAVE LEFT

\begin{tabular}{|} 
Number Left & Urban & Rural & Total \\
\hline $0-3$ & 9 & 3 & 12 \\
\hline $4-6$ & 3 & 1 & 4 \\
\hline $7-9$ & 0 & 1 & 1 \\
\hline $10-12$ & 0 & 1 & 1 \\
\hline No.Response & 1 & 0 & 1 \\
\hline Total & 13 & 6 & $19 \mathrm{~N}$ \\
\hline
\end{tabular}


TABLE 5

NUMBER OF MEMBERS WHO HAVE JOINED SINCE FORMATION

\begin{tabular}{|c|c|c|c|}
\hline Number of New Members & Urban & Rural & Total \\
\hline $0-3$ & 8 & 3 & 11 \\
\hline-6 & 3 & 1 & 4 \\
\hline 9 & 0 & 0 & 0 \\
\hline $10-12$ & 0 & 0 & 0 \\
\hline $13-15$ & 1 & 1 & 2 \\
\hline $16-18$ & 0 & 1 & 1 \\
\hline No response & $I$ & 0 & 1 \\
\hline Total & 13 & 6 & $19 \mathrm{~N}$ \\
\hline
\end{tabular}

TABLE 6

NUMBER OF CURRENT MEMBERS WHO HAVE BEEN IN RESIDENCE 6 MONTHS OR LONGER

Number in residence

6 months or longer

Urban . Rural

Total

\begin{tabular}{|c|c|c|c|}
\hline $0-3$ & 2 & 0 & 2 \\
\hline $4-6$ & 6 & 1 & 7 \\
\hline $7-9$ & 3 & 2 & 5 \\
\hline $10-12$ & 1 & 2 & 3 \\
\hline $13-15$ & 0 & 0 & 0 \\
\hline $16-18$ & 0 & 0 & 0 \\
\hline $19-21$ & 0 & 1 & 1 \\
\hline 150 & 1 & 0 & 1 \\
\hline Total & & 6 & $19 \mathrm{~N}$ \\
\hline
\end{tabular}


TABLE 7

NUMBER OF CURRENT MEMBERS

Number of current members
\begin{tabular}{|c|c|c|c|}
\hline $0-3$ & Urban & Rural & Total \\
\hline $4-6$ & 0 & 0 & 0 \\
\hline $7-9$ & 7 & 1 & 8 \\
\hline $10-12$ & 4 & 2 & 6 \\
\hline $13-15$ & 1 & 2 & 3 \\
\hline $16-18$ & 0 & 0 & 0 \\
\hline $19-21$ & 0 & 0 & 0 \\
\hline 1501 & 0 & 1 & 1 \\
\hline Total & 1 & 0 & 1 \\
\hline Estimate & 13 & 6 & $19 \mathrm{~N}$ \\
\hline
\end{tabular}

TABLE 8

NUMBER OF MEN CURRENTLY RESIDENT

\begin{tabular}{|c|c|c|c|}
\hline Number of men & Urban & Rural & Total \\
\hline 0 & 0 & 1 & 1 \\
\hline 1 & 2 & 0 & 2 \\
\hline 2 & 0 & 1 & 1 \\
\hline 3 & 6 & 0 & 6 \\
\hline 4 & 2 & 1 & 3 \\
\hline 5 & 2 & 2 & 4 \\
\hline 6 & 0 & 0 & 0 \\
\hline 7 & 0 & 1 & 1 \\
\hline No response & 1 & 0 & 1 \\
\hline Total & 13 & 6 & $19 \mathrm{~N}$ \\
\hline
\end{tabular}


TABL,I: 9

NUMBER OF WOMEN CURRENTLY RESIDEN'T

\begin{tabular}{|c|c|c|c|}
\hline Number of women & Urban & Rural & Total \\
\hline 0 & 0 & 0 & 0 \\
\hline 1 & 0 & 0 & 0 \\
\hline 2 & 5 & 2 & 7 \\
\hline 3 & 5 & 0 & 5 \\
\hline 4 & 1 & 2 & 3 \\
\hline 5 & 1 & 1 & 2 \\
\hline 6 & 0 & 0 & 0 \\
\hline 7 & 0 & 0 & 0 \\
\hline 8 & 0 & 1 & 1 \\
\hline No response & 1 & 0 & 1 \\
\hline Total & 13 & 6 & $19 \mathrm{~N}$ \\
\hline
\end{tabular}

TABLE 10

NUMBER OF CHILDREN UNDER 14 CURRENTLY RESIDENT

\begin{tabular}{|c|c|c|c|}
\hline Number of children under 14 & Urban & Rural & Total \\
\hline 0 & 8 & 1 & 9 \\
\hline 1 & 2 & 2 & 4 \\
\hline 2 & 0 & 1 & 1 \\
\hline 3 & 1 & 0 & 1 \\
\hline 4 & 1 & 2 & 3 \\
\hline 25 & 1 & 0 & 1 \\
\hline Total & 13 & 6 & $19 \mathrm{~N}$ \\
\hline 1. Estimate & & & \\
\hline
\end{tabular}


TABLE 11

( OF COMMUNE ADULTS ) CURRENTLY RESIDENT

\begin{tabular}{|c|c|c|c|}
\hline Number of older children & Urban & Rural & Total \\
\hline 0 & 12 & 5 & 17 \\
\hline 1 & 0 & 0 & 0 \\
\hline 2 & 0 & 1 & 1 \\
\hline No response & 1 & 0 & 1 \\
\hline Total & 13 & & $19 \mathrm{~N}$ \\
\hline
\end{tabular}

TABLE 12

NUMBER OF MEMBERS IN ONGOING COUPLE RELATIONSHIPS

\begin{tabular}{|c|c|c|c|}
\hline Number & Urban & Rural & Total \\
\hline 0 & 1 & 1 & 2 \\
\hline 1 & 0 & 0 & 0 \\
\hline 2 & 3 & 0 & 3 \\
\hline 3 & 2 & 0 & 2 \\
\hline 4 & 4 & 2 & 6 \\
\hline 5 & 1 & 0 & 1 \\
\hline 6 & 1 & 0 & 1 \\
\hline 7 & 0 & 0 & 0 \\
\hline 8 & 0 & 2 & 2 \\
\hline No response & 1 & 1 & 2 \\
\hline Total & 13 & 6 & $19 \mathrm{~N}$ \\
\hline
\end{tabular}


TABLE 13

NUMBER OF MEMBERS WHO ARE LEGALLY MARRIED

\begin{tabular}{|c|c|c|c|} 
Number & Urban & Rural & Total \\
\hline 0 & 5 & 3 & 8 \\
\hline 1 & 0 & 0 & 0 \\
\hline 2 & 5 & 1 & 6 \\
\hline 3 & 0 & 0 & 0 \\
\hline 4 & 1 & 2 & 3 \\
\hline 5 & 0 & 0 & 0 \\
\hline 6 & 1 & 0 & 1 \\
\hline No response & 1 & 0 & 1 \\
\hline Total & 13 & 6 & $19 \mathrm{~N}$ \\
\hline
\end{tabular}

TABLE 14

SETTING OF COMMUNE

Setting

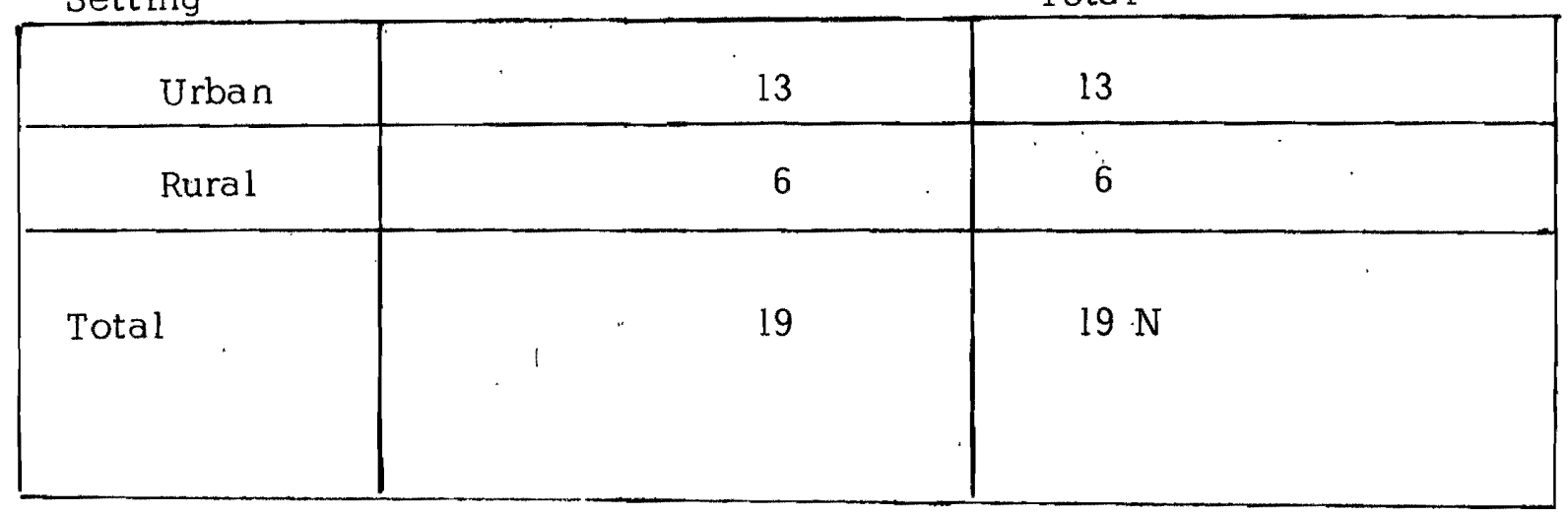


TABLE 15

CONNECTIONS WITH OTHER COMMUNES

\begin{tabular}{|l|c|c|c|}
\hline Connections & Urban & Rural & Total \\
\hline A separate entity & 10 & 5 & 15 \\
\hline Part of a larger network of communes & 3 & 0 & 3 \\
\hline $\begin{array}{l}\text { Receiving some direction from } \\
\text { outside commune itself }\end{array}$ & 0 & 1 & 1 \\
\hline Total & 13 & 6 & $19 \mathrm{~N}$ \\
\hline
\end{tabular}

TABLE 16

CRITERIA FOR BELONGING

\begin{tabular}{|l|c|c|c|}
\hline Criteria & Urban & Rural & Total \\
\hline Tinancial & 2 & 3 & 3 \\
\hline Personal interest in joining & 2 & 0 & 5 \\
\hline Prior friend ship & 3 & 1 & 3 \\
\hline Mutual compatibility & 2 & 0 & 0 \\
\hline Certa in needed skill & 0 & 1 & 9 \\
\hline Similar values & 8 & 1 & 2 \\
\hline Working together on common task & 1 & 2 & 6 \\
\hline Decision of the group & 4 & 1 & 6 \\
\hline Other & 5 & 0 & 0 \\
\hline No response & 0 & 10 & $37^{1}$ \\
\hline Total & 27 & & \\
\hline Multiple answers were given in many cases. &
\end{tabular}


TABLE 17

WHETHER OR NOT COMMUNE IS INTERESTED IN NEW MEMBERS

\begin{tabular}{|l|c|c|c|}
\hline Whether or not & Urban & Rural & Total \\
\hline Yes & 8 & 5 & 13 \\
\hline No & 5 & 1 & 6 \\
\hline No response & 1 & 0 & 1 \\
\hline Total & 14 & 6 & $20^{1}$ \\
\hline 1. One group answered yes and no. & & \\
\hline
\end{tabular}

TABLE 18

FACTORS AFFECTING INTEREST IN NEW MEMBERS

\begin{tabular}{|l|c|c|c|}
\hline Factors & Urban & Rural & Total \\
\hline Usefulness to the group & 1 & 2 & 3 \\
\hline $\begin{array}{l}\text { Presence of criteria for } \\
\text { belonging l }\end{array}$ & 1 & 0 & 1 \\
\hline Ava ilability of space & 7 & 1 & 8 \\
\hline Other & 0 & 2 & 2 \\
\hline No response & 4 & 2 & 6 \\
\hline $\begin{array}{l}\text { Total } \\
\text { 2. This refers to criteria listed in Table 16. }\end{array}$ & 7 & $20^{2}$ \\
\hline
\end{tabular}


TABLE 19

WHERE COUPLES LIVE

\begin{tabular}{|l|c|c|c|}
\hline $\begin{array}{l}\text { Where } \\
\text { In separate houses or } \\
\text { a partments }\end{array}$ & 0 & Trban & Total \\
\hline In a single house & 11 & 0 & 6 \\
\hline Other & 0 & 0 & 11 \\
\hline No response & 2 & 0 & 0 \\
\hline Total & 13 & 6 & 2 \\
\hline
\end{tabular}

TABLE 20

WHERE SINGLE PERSONS LIVE

\begin{tabular}{|l|c|c|c|} 
Where & Urban & Total \\
\hline $\begin{array}{l}\text { In separate houses or } \\
\text { a partments }\end{array}$ & 0 & 5 & 5 \\
\hline In a single house & 12 & 0 & 12 \\
\hline Other & 0 & 0 & 0 \\
\hline No response & 1 & 1 & 21 \\
\hline & 13 & 6 & $19 \mathrm{~N}$ \\
\hline Total & One of these groups has no single persons. & \\
\hline
\end{tabular}


TABLE 21

NATURE OF GROUPS' FACILITIES 1

Nature of
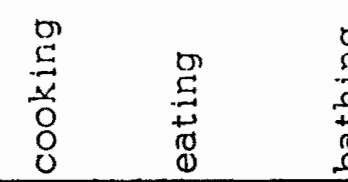

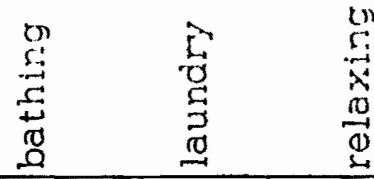

Total

\begin{tabular}{|l|c|c|c|c|c|c|}
\hline Separate by couple or family & $0 / 1$ & $0 / 1$ & $1 / 2$ & $0 / 0$ & $2 / 4$ & $3 / 8=11$ \\
\hline $\begin{array}{l}\text { Separate for individual } \\
\text { single persons }\end{array}$ & $0 / 0$ & $0 / 0$ & $2 / 0$ & $0 / 0$ & $4 / 2$ & $6 / 2=8$ \\
\hline Communal for single persons & $0 / 0$ & $0 / 0$ & $0 / 0$ & $0 / 0$ & $0 / 0$ & $0 / 0=0$ \\
\hline Communal for all & $13 / 6$ & $13 / 6$ & $11 / 6$ & $12 / 6$ & $12 / 5$ & $61 / 29=90$ \\
\hline Other & $0 / 0$ & $0 / 0$ & $1 / 0$ & $1 / 0$ & $0 / 0$ & $2 / 0=2$ \\
\hline & & & & & & \\
Total & $13 / 7$ & $13 / 7$ & $15 / 8$ & $13 / 6$ & $18 / 11$ & $72 / 39=111$ \\
Total & 20 & 20 & 23 & 19 & 29 & $111^{2}$ \\
\hline
\end{tabular}

1. Urban/Rural indicates manner in which divided:

2. Multiple answers were given in some cases.

TABLE 22

WHERE CHILDREN SLEEP

Where

Urban

Rural

Total

\begin{tabular}{|c|c|c|c|}
\hline In a special children's house & 0 & 0 & 0 \\
\hline In a room near parent (s) & 1 & 3 & 4 \\
\hline In parent (s)'room & 1 & 1 & 2 \\
\hline Other & 3 & 2 & 5 \\
\hline No response & 8 & 0 & 1 \\
\hline Total : & 13 & 6 & $19 \mathrm{~N}$ \\
\hline 1. None of these groups have children resident. & \\
\hline
\end{tabular}


WHETHER OR NOT CHILDREN HAVE BEEN BORN TO MEMBERS SINCE FORMATION OF THE COMMUNE

\begin{tabular}{|c|c|c|c|} 
Whether or not & Urban & Rural & Total \\
\hline Yes & 1 & 4 & 5 \\
\hline No & 12 & 2 & 14 \\
\hline Total & 13 & 6 & $19 \mathrm{~N}$ \\
\hline
\end{tabular}

TABLE 24

WHETHER OR NOT THE COMMUNE OWNS PROPERTY

Whether or not
\begin{tabular}{|c|c|c|c|}
\hline Yes & Urban & Rural & Total \\
\hline No & 5 & 6 & 11 \\
\hline Total & 8 & 0 & 8 \\
\hline
\end{tabular}

TABLE 25

HOW PROPERTY WAS OBTAINED

How Urban $\quad$ Rural $\quad$ Total

\begin{tabular}{|l|c|c|c|}
\hline As a gift & 0 & 0 & 0 \\
\hline From members' contributions & 1 & 3 & 4 \\
\hline Purcha sed by one member & 0 & 1 & 1 \\
\hline Purcha sed by one family & 0 & 0 & 0 \\
\hline Other & 4 & 3 & 7 \\
\hline No response & 8 & 0 & $8^{1}$ \\
\hline Total & 13 & 7 & $20^{2}$ \\
\hline 1. Light groups own no property. & & \\
2. One group answered in two categories. & \\
\hline
\end{tabular}


TABLE 26

HOW PROPERTY IS HELD

\begin{tabular}{|c|c|c|c|}
\hline How & Urban & Rural & Total \\
\hline In trust & 0 & 0 & 0 \\
\hline As a corporation & 0 & 2 & 2 \\
\hline By individual (s) & 1 & 2 & 3 \\
\hline Jointly by all adults & 2 & 2 & 4 \\
\hline Other & 2 & 4 & 6 \\
\hline No response & 8 & 0 & $8^{1}$ \\
\hline Total & 13 & 10 & $23^{2}$ \\
\hline
\end{tabular}

TABLE 27

HOW PROPERTY WOULD BE DISPOSED OF IF COMMUNE WERE TO DISBAND

\begin{tabular}{|l|c|c|c|}
\hline How & Urban & 0 & Total \\
\hline Sold and proceed s distributed equally & 0 & 0 & 3 \\
\hline Haven't decided & 3 & 1 & 1 \\
\hline Donated to non-profit organization & 0 & 0 & 0 \\
\hline Shares sold to one or more members & 0 & 6 & 8 \\
\hline Other & 2 & 0 & 8 \\
\hline No response & 8 & 7 & $20^{2}$ \\
\hline Total & 13 & 1 \\
\hline
\end{tabular}

1. Eight groups did not answer as they have no property.

2. One group gave more than one answer. 
TABLE 28

WHETHER OR NOT THOSE GROUPS HAVING NO

PROPERTY PLAN TO OWN PROPERTY IF THIS IS POSSIBLE IN THE FUTURE

Whether or not

Urban Rural

Total

\begin{tabular}{|c|c|c|c|}
\hline Yes & 5 & 0 & 5 \\
\hline No & 1 & 0 & 1 \\
\hline Not sure & 1 & 0 & 1 \\
\hline No response & 6 & 6 & 121 \\
\hline Total & 13 & 6 & $19 \mathrm{~N}$ \\
\hline
\end{tabular}

1. Eleven of these groups own property.

TABLE 29

HOW FINANCIAL CONTRIBUTIONS FOR SUPPORT

OF THE COMMUNE ARE MADE

How
\begin{tabular}{|c|c|c|c|}
\hline Equally by all members & 8 & 2 & Rural \\
\hline By ability to pay & 2 & 2 & 10 \\
\hline Other & 3 & 2 & 4 \\
\hline No response & 1 & 0 & 5 \\
\hline Total & 14 & 6 & 20 \\
\hline $1 . \quad$ One group gave two answers. & & & 1 \\
\hline
\end{tabular}


TABLE 30

WHETHER OR NOT CERTAIN PERSONS ARE

EXEMPT FROM FINANCIAL CONTRIBUTIONS

Whether or not

Urban

Rural

Total

\begin{tabular}{|l|c|c|c|}
\hline Yes & 4 & 1 & 5 \\
\hline No & 8 & 4 & 12 \\
\hline No response & 2 & 1 & 3 \\
\hline Total & 14 & 6 & $20^{2}$ \\
\hline
\end{tabular}

1. Two of these were from the pre-test where this question was not included

2. One group answered yes and no.

TABLE 31

ON WHAT BASIS CERTAIN PERSONS ARE EXEMPT FROM FINANCIAL CONTRIBUTIONS

On what basis

Urban

Rural

Total

\begin{tabular}{|l|c|c|c|}
\hline Mothers with small children & 0 & 0 & 0 \\
\hline $\begin{array}{l}\text { Persons with smaller } \\
\text { potential income }\end{array}$ & 1 & 0 & 1 \\
\hline Handicapped & 0 & 0 & 0 \\
\hline $\begin{array}{l}\text { Responsible for service } \\
\text { Outside commune }\end{array}$ & 3 & 0 & 3 \\
\hline Other & 0 & 1 & 1 \\
\hline No response & 9 & 5 & $14^{1}$ \\
\hline $\begin{array}{l}\text { Total } \\
\text { 1. All of the se groups either did not answer or answered no to the quest- } \\
\text { ion of whether certain persons are exempt from financial contributions. }\end{array}$
\end{tabular}


TABLE 32

\section{KINDS OF INCOME PRODUCING WORK} $\frac{\text { DONE BY MEN AND WOMEN }}{1}$

\begin{tabular}{|c|c|c|c|}
\hline Kinds & Men & Women & Total \\
\hline Paid jobs in outside community & $24 / 16$ & $20 / 12$ & $44 / 28=72$ \\
\hline Farming & $0 / 0$ & $0 / 5$ & $0 / 5=5$ \\
\hline Gardening & $0 / 0$ & $0 / 0$ & $0 / 0=0$ \\
\hline Crafts & $0 / 5$ & $0 / 4$ & $0 / 9=9$ \\
\hline Other & $0 / 5$ & $0 / 4$ & $0 / 9=9$ \\
\hline $\begin{array}{l}\text { Total } \\
\text { Total }\end{array}$ & $\begin{array}{c}24 / 26 \\
50\end{array}$ & $\begin{array}{c}20 / 25 \\
45\end{array}$ & $\begin{array}{l}44 / 51=95^{2} \\
95\end{array}$ \\
\hline \multicolumn{4}{|c|}{$\begin{array}{l}\text { 1. Urban/Rural indicates manner in which divided. } \\
\text { 2. Multiple answers occurred in many cases. No income producing work was } \\
\text { indicated for many respondents. }\end{array}$} \\
\hline
\end{tabular}

\section{TABLE 33}

WHETHER.OR NOT THE ENTIRE COMMUNE GETS TOGETHER TO PERFORM A COMMON TASK

\begin{tabular}{|l|c|c|c|}
\hline Whether or not & Urban & Rural & Total \\
\hline Yes & 12 & 4 & 16 \\
\hline No & 1 & 2 & 3 \\
\hline Total & & & \\
\hline
\end{tabular}


HOW OFTEN THE ENTIRE COMMUNE GETS

TOGETHER TO PERFORM A COMMON TASK

\begin{tabular}{|c|c|c|c|}
\hline How often & Urban & Rural & Total \\
\hline Weekly or more often & 5 & 1 & 6 \\
\hline About monthly & 2 & 0 & 2 \\
\hline Vague (but do meet-often) & 1 & 1 & 2 \\
\hline Vague (but do meet - not often) & 2 & 1 & 3 \\
\hline By need & 0 & 1 & 1 \\
\hline Other & 2 & 0 & 2 \\
\hline No response & 1 & 2 & 31 \\
\hline Total & 13 & 6 & $19 \mathrm{~N}$ \\
\hline
\end{tabular}

1. Three groups did not respond as they do not get together for this purpose.

TABLE 35

TASKS WHICH THE ENTIRE GROUP GETS TOGETHER TO PERFORM COMMONLY

Tasks

Urban

Rural

Total

Social and/or recreational activity Building and property maintenance Food preparation Outside job Cooperative craft activity Outside service project

Political activity Child-related project Other No response Total

\begin{tabular}{|c|c|c|}
\hline 7 & 1 & 8 \\
\hline 9 & 2 & 11 \\
\hline 1 & 0 & 1 \\
\hline 0 & 1 & 1 \\
\hline 0 & 0 & 0 \\
\hline 2 & 0 & 2 \\
\hline 0 & 0 & 1 \\
\hline 6 & 0 & 0 \\
\hline 1 & 2 & 8 \\
\hline 27 & 2 & 3 \\
\hline
\end{tabular}

1. Several groups gave multiple answers. 
HOW OFTEN CROUP MEETINGS ARE HELD

IN WHICH ENTIRE COMMUNE GETS TOGETHER TO DISCUSS COMMON CONCERNS

\begin{tabular}{l} 
How often \\
\begin{tabular}{|l|c|c|c|}
\hline Never & Urban & Rural & Total \\
\hline Daily & 0 & 0 & 0 \\
\hline Weekly & 0 & 0 & 0 \\
\hline Biweekly & 5 & 1 & 6 \\
\hline Monthly & 1 & 1 & 2 \\
\hline Other & 1 & 0 & 1 \\
\hline Total & 6 & 4 & 10 \\
\hline
\end{tabular} \\
\hline
\end{tabular}

TABLE 37

WHETHER OR NOT ATTENDANCE IS GENERALLY EXPECTED AT COMMUNE MEETINGS

Whether or not
\begin{tabular}{|c|c|c|c|}
\hline Yes & 11 & 4 & Urban \\
\hline No & 0 & 0 & 15 \\
\hline $\begin{array}{l}\text { Happens when everyone is } \\
\text { available }\end{array}$ & 0 & 1 & 1 \\
\hline No response & 2 & 1 & 31 \\
\hline Total & 13 & 6 & $19 \mathrm{~N}$ \\
\hline 1. Question was not included in pre-test. & & \\
\hline
\end{tabular}


TABLE 38:

HOW THE PATTERN OF GROUP MEETINGS HAS CHANGED IF IT HAS CHANGED

\begin{tabular}{|l|c|c|c|}
\hline How & Urban & Rural & Total \\
\hline Less frequently & 4 & 4 & 8 \\
\hline More frequently & 1 & 0 & 1 \\
\hline Other & 1 & 0 & 1 \\
\hline No response & 7 & 2 & 9 \\
\hline Total & 13 & 6 & $19 \mathrm{~N}$ \\
\hline
\end{tabular}

TABLE 39

WHY THE PATTERN OF GROUP MEETINGS HAS CHANGED. IF IT HAS CHANGED ( FOR THOSE WHO ANSWERED LESS FREQUENTLY)

\begin{tabular}{|c|c|c|c|}
\hline Why & Urban & Rural & Total \\
\hline Things got organized & 1 & 2 & 3 \\
\hline $\begin{array}{l}\text { Group cohesiveness adequate } \\
\text { without meetings }\end{array}$ & $\underline{0}$ & 0 & 0 \\
\hline Lack of interest & 1 & 0 & 1 \\
\hline Meetings were negative & $\theta$ & 2 & 2 \\
\hline Other & 1 & 1 & 2 \\
\hline No response & 10 & 1 & 11 \\
\hline Total & 13 & 6 & $19 \mathrm{~N}$ \\
\hline
\end{tabular}


TABLE 40

WHY THE PATTERN OF GROUP MEETINGS HAS CHANGED, IF IT HAS CHANGED (FOR THOSE WHO ANSWERED MORE FREQUENT'LY)

\begin{tabular}{|c|c|c|c|}
\hline Why & Urban & Rural & Total \\
\hline Needed to & 1 & 0 & 1 \\
\hline Wanted to & 1 & 0 & 1 \\
\hline No résponse & 12 & 6 & 18 \\
\hline Total & 13 & 6 & $20^{1}$ \\
\hline
\end{tabular}

I. One group that answered more frequently gave two reasons.

\section{TABLE 41}

SEX OF RESPONDENTS.

Sex
\begin{tabular}{|l|c|}
\hline Women & Number of respondents \\
\hline Men & 46 \\
\hline & 48 \\
\hline Total & $94 \mathrm{~N}$ \\
\hline
\end{tabular}


TABLE 42

AGE OF RESPONDENTS

\begin{tabular}{|c|c|c|c|}
\hline Age & Women & Men & Total \\
\hline $0-5$ & 0 & 0 & 0 \\
\hline $6-10$ & 0 & 1 & 1 \\
\hline $11-15$ & 0 & 1 & 1 \\
\hline $16-20$ & 4 & 4 & 8 \\
\hline $21-25$ & 17 & 20 & 37 \\
\hline $26-30$ & 18 & 17 & 35 \\
\hline $31-35$ & 2 & 2 & 4 \\
\hline $36-40$ & 2 & 0 & 2 \\
\hline $41-45$ & 1 & 0 & 1 \\
\hline $46-50$ & 0 & 1 & 1 \\
\hline $51-55$ & 1 & 1 & 2 \\
\hline $56-60$ & 1 & 1 & 0 \\
\hline $61-65$ & & & \\
\hline
\end{tabular}


TABLE 43

\section{WHETHER OR NOT RESPONDENTS HAVE CHLLDEN}

\begin{tabular}{|c|c|c|c|} 
Whether or not & Women & Men & Total \\
\hline Yes & 12 & 12 & 24 \\
\hline No & 34 & 33 & 67 \\
\hline No response & 0 & 3 & 3 \\
\hline Total & 46 & 48 & $94 \mathrm{~N}$ \\
\hline
\end{tabular}

TABLE 44

SEX AND AGE OF CHILDREN

\begin{tabular}{|c|c|c|c|}
\hline Age & Girls & Boys & Total \\
\hline Under 2 & 1 & 1 & 2 \\
\hline $2-5$ & 5 & 2 & 7 \\
\hline $6-12$ & 4 & 7 & 11 \\
\hline $12-21$ & 2 & 2 & 4 \\
\hline Total & & & $24 \mathrm{~N}$ \\
\hline
\end{tabular}


TABLE 45

WHETHER OR NOT RESPONDENTS ARE IN COUPLE RELATIONSHIPS

\begin{tabular}{|c|c|c|c|}
\hline Whether or not & Women & Men & \multicolumn{1}{c}{ Total } \\
\hline Yes & 25 & 29 & 54 \\
\hline No & 19 & 12 & 31 \\
\hline No response & 2 & 7 & 9 \\
\hline Total & 46 & 48 & $94 \mathrm{~N}$ \\
\hline
\end{tabular}

TABLE 46

WHETHER OR NOT PARTNERS ARE RESIDENT IN THE COMMUNE, FOR THOSE WHO ARE IN COUPLE REIATIONSHIPS

\begin{tabular}{|c|c|c|c|}
\hline Whether or not & Women & Men & Total \\
\hline Yes & 21 & 25 & 46 \\
\hline No & 3 & 5 & 8 \\
\hline No response & 22 & 18 & 40 \\
\hline Total & 46 & 48 & $94 \mathrm{~N}$ \\
\hline
\end{tabular}


TABLE 47.

EDUCATIONAL LEVEL ATTAINED

Educational level 1

Women

Men

Total

\begin{tabular}{|l|c|c|c|}
\hline High school or less & 5 & 3 & 8 \\
\hline Some college & 13 & 18 & 31 \\
\hline College completed & 13 & 9 & 22 \\
\hline $\begin{array}{l}\text { Some graduate study } \\
\text { Gompleted graduate study }\end{array}$ & 10 & 10 & 20 \\
\hline No response & 4 & 7 & 11 \\
\hline Total & 1 & 1 & 2 \\
\hline
\end{tabular}

1. Three men and one woman also listed specialized training in addition to one of the other categories. 
TABLE 48

OCCUPATION (S) OF RESPPONDENTS PRIOR TO JOINING THE COMMUNE

\begin{tabular}{|c|c|c|c|}
\hline Occupations & Women & Men & Total \\
\hline Proprietors, managers, owners & 4 & 4 & 8. \\
\hline Professional, semi-professional & 25 & 20 & 45 \\
\hline Clerical service & 18 & 8 & 26 \\
\hline Skilled - nonfarm & 5 & 11 & 16 \\
\hline Skilled - farm & 0 & 2 & 2 \\
\hline Skilled - crafts & 1 & 1 & 2 \\
\hline Unskilled - nonfarm & 1 & 3 & 4 \\
\hline Unskilled - farm & 1 & 1 & 2 \\
\hline Students & 16 & 11 & 27 \\
\hline Family 1 & 3 & 1 & 4 \\
\hline Other & 6 & 4 & 10 \\
\hline No response & 0 & 1 & 1 \\
\hline Total : & 80 & 67 & $147^{2}$ \\
\hline
\end{tabular}

1. Some respondents listed family roles as occupations, for example: husband, wife, son, daughter.

2. Many respondents listed more than one occupation. 
TABLE 49

PRESENT OCCUPATION OF RESPONDENTS

\begin{tabular}{|c|c|c|c|}
\hline Occupations & Women & Men & Total \\
\hline Proprietors, managers, owners & 3 & 2 & 5 \\
\hline Professional, semi-professional & 15 & 9 & 24 \\
\hline Clerical service & 1 & 7 & 8 \\
\hline Skilled - nonfarm & 11 & 7 & 18 \\
\hline Skilled - farm & 6 & 5 & 11 \\
\hline Skilled - crafts & 1 & 2 & 3 \\
\hline Unskilled - nonfarm & 2 & 1 & 3 \\
\hline Unskilled - farm & 0 & 2 & 2 \\
\hline Students & 6 & 6 & 12 \\
\hline Family $^{1}$ & 4 & 1 & 5 \\
\hline Other & 13 & 10 & 23 \\
\hline No response & 0 & 1 & 1 \\
\hline Total & 62 & 53 & $115^{2}$ \\
\hline \multicolumn{4}{|c|}{$\begin{array}{l}\text { 1. Some respondents listed family roles as occupations, for example: } \\
\text { husband, wife, son, daughter. } \\
\text { 2. Many respondents listed more than one occupation. }\end{array}$} \\
\hline
\end{tabular}


TABLE 50

PRIMARY REASON(S) FOR IORMATIUN (I) (OMMLINE:

\begin{tabular}{|c|c|c|c|}
\hline Reasons & Women & Men & Total \\
\hline Value system & 13 & 10 & 23 \\
\hline Personal growth & 6 & 10 & 16 \\
\hline $\begin{array}{l}\text { To live as a group with compatible } \\
\text { people }\end{array}$ & 12 & 12 & 24 \\
\hline $\begin{array}{l}\text { Focus on support from group and/or } \\
\text { strengthening of relationships }\end{array}$ & 14 & 16 & 30 \\
\hline Ecology & 5 & 1 & 6 \\
\hline Good for children & 3 & 1 & 4 \\
\hline Good for parent rearing children & 0 & 0 & 0 \\
\hline Economics & 15 & 10 & 25 \\
\hline Serving others & 2 & 7 & 9 \\
\hline Escape & 3 & 0 & 3 \\
\hline As an experiment & 5 & 5 & 10 \\
\hline Living close to the land & 6 & 4 & 10 \\
\hline Lessening of household burdens & 3 & 1 & 4 \\
\hline Other & 6 & 14 & 20 \\
\hline No response & 4 & 2 & 6 \\
\hline Total & 97 & 93 & $190^{1}$ \\
\hline
\end{tabular}


TABLE 51

PRIMARY REASONS FOR INDIVIDUAL JOINING COMMUNE-

\begin{tabular}{|c|c|c|c|}
\hline Reasons & Women & Men & Total \\
\hline Value system & 6 & 6 & 12 \\
\hline Personal growth & il & 11 & 22 \\
\hline $\begin{array}{l}\text { To live as a group with compatible } \\
\text { people }\end{array}$ & 24 & 14 & 38 \\
\hline $\begin{array}{l}\text { Focus on support from group and/ } \\
\text { or strengthening of relationships }\end{array}$ & 13 & 14 & 27 \\
\hline Ecology & 2 & 0 & 2 \\
\hline Good for children & 3 & 2 & 5 \\
\hline Good for parent rearing children & 0 & 0 & 0 \\
\hline Economics & 9 & 11 & 20 \\
\hline Serving others & 2 & 2 & 4 \\
\hline Escape & 1 & 3 & 4 \\
\hline An an experiment & 4 & 3 & 7 \\
\hline Living close to the land & 7 & 5 & 12 \\
\hline Lessening of household burden & 5 & 1 & 6 \\
\hline A personal relationship & 13 & 22 & 35 \\
\hline Adventure & 1 & 3 & 4 \\
\hline Other & 3 & 5 & 8 \\
\hline No response & 0 & 0 & 0 \\
\hline Total & 104 & 102 & $206^{1}$ \\
\hline
\end{tabular}


TABLE 52

NUMBER OF MONTHS LIVED IN THIS COMMUNE

\begin{tabular}{|c|c|c|c|}
\hline Number of months & Women & 6 & 19 \\
\hline $0-5$ & 13 & 8 & 8 \\
\hline $6-10$ & 0 & 8 & 18 \\
\hline $11-15$ & 10 & 5 & 8 \\
\hline $16-20$ & 3 & 4 & 9 \\
\hline $21-25$ & 5 & 2 & 7 \\
\hline $26-30$ & 5 & 1 & 3 \\
\hline $31-35$ & 2 & 4 & 5 \\
\hline $36-40$ & 1 & 10 & 17 \\
\hline No response & 7 & 48 & $94 \mathrm{~N}$ \\
\hline Total & 46 & & 10 \\
\hline
\end{tabular}

1. Fourteen of these were from pre-test where this question was not included.

TABLE 53

WHETHER OR NOT RESPONDENTS HAVE LIVED IN OTHER COMMUNES

\begin{tabular}{|l|c|r|c|} 
Whether or not & Women & Men & Total \\
\hline Yes & 21 & 18 & 39 \\
\hline No & 24 & 30 & 54 \\
\hline No response & 1 & 0 & 1 \\
\hline Total & 46 & 48 & $94 \mathrm{~N}$ \\
\hline
\end{tabular}




\section{TABLE 54}

\section{NUMBER OF OTHER COMMUNES RESPONDENTS HAVE LIVED IN}

Number of other communes
\begin{tabular}{|c|c|c|c|}
\hline 1 & Women & Men & Total \\
\hline 2 & 7 & 9 & 16 \\
\hline 3 & 8 & 4 & 12 \\
\hline 4 & 1 & 1 & 2 \\
\hline 5 & 2 & 1 & 3 \\
\hline 6 & 0 & 0 & 0 \\
\hline 7 & 1 & 1 & 2 \\
\hline 8 & 0 & 0 & 0 \\
\hline 9 & 0 & 0 & 0 \\
\hline Unspecified & 0 & 1 & 1 \\
\hline No response & 2 & 1 & $94 \mathrm{~N}$ \\
\hline Total & 25 & 30 & 55 \\
\hline
\end{tabular}


TABLE 55

NUMBER OF MONTHS RESPONDENTS

HAVE LIVED IN OTHER COMMUNES

\begin{tabular}{|c|c|c|c|}
\hline Number of months & Women & Men & Total \\
\hline $0-6$ & 6 & 3 & 9 \\
\hline $7-12$ & 3 & 5 & 8 \\
\hline $13-18$ & 1 & 0 & 1 \\
\hline $19-24$ & 5 & 4 & 9 \\
\hline $25-30$ & 2 & 0 & 2 \\
\hline $31-36$ & 0 & 1 & 1 \\
\hline $37-42$ & 0 & 0 & 0 \\
\hline $43-48$ & 1 & 1 & 2 \\
\hline 60 & 1 & 1 & 5 \\
\hline Unspecified & 2 & 3 & 54 \\
\hline No response & 25 & 30 & $\mathrm{~N}$ \\
\hline
\end{tabular}


TABLE 56

PERCEPTIONS OF REASONS PEOPLE LEAVE COMMUNES

\begin{tabular}{|c|c|c|c|}
\hline Reasons & Women & Men & Total \\
\hline Interpersonal conflicts & 33 & 26 & 59 \\
\hline Differences in philosophy & 4 & 3 & 7 \\
\hline Intensity of encounters & 3 & 1 & 4 \\
\hline Need for more personal control & 4 & 5 & 9 \\
\hline Unsuccessful couple relationship & 1 & 3 & 4 \\
\hline Differences over child-rearing & 1 & 2 & 3 \\
\hline Changing goals. & 9 & 7 & 16 \\
\hline External circumstances & 8 & 4 & 12 \\
\hline Lack of commitment to group & 5 & 9 & 14 \\
\hline $\begin{array}{l}\text { Desire for more contact with } \\
\text { outside world }\end{array}$ & 2 & 4 & 6 \\
\hline Can't adapt to new life-style & 6 & 9 & 15 \\
\hline Disappointed with expectations & 7 & 5 & 12 \\
\hline Need for more privacy & 8 & 5 & 13 \\
\hline Other & 9 & 1.1 & 20 \\
\hline No response & 1 & 3 & 4 \\
\hline Uncodable & 2 & 0 & 2 \\
\hline Total & 103 & 97 & $200^{1}$ \\
\hline
\end{tabular}


TABLE 57

LENGTH OI TIME RESPONDENTS PLAN

TO REMAIN IN THE COMMUNE

\begin{tabular}{|c|c|c|c|}
\hline Length of time & Women & Men & Total \\
\hline 3 months or less & 2 & 6 & 8 \\
\hline $4-6$ months & 0 & 0 & 0 \\
\hline $7-9$ months & 3 & 2 & 5 \\
\hline $10-12$ months & 8 & 5 & 13 \\
\hline $13-24$ months & 0 & 1 & 1 \\
\hline $25-36$ months & 0 & 0 & 0 \\
\hline $37-48$ months & 1 & 0 & 1 \\
\hline Indefinitely & 24 & 24 & 48 \\
\hline Other & 8 & 5 & 13 \\
\hline No responsé & 0 & 5 & 5 \\
\hline Totàl & 46 & 48 & $94 \mathrm{~N}$ \\
\hline
\end{tabular}


TABLE 58

\section{PERCEPTIONS OF WHETHER OR NOT SEX ROLES WERE DISCUSSED IN THE FORMATIVE PERIOD}

\begin{tabular}{|l|c|c|c|}
\hline Whether or not & Women & Men & Total \\
\hline Yes & 25 & 19 & 44 \\
\hline No & 8 & 7 & 35 \\
\hline No response & 13 & 22 & $94 \mathrm{~N}$ \\
\hline Total & 46 & 48 & \\
\hline $\begin{array}{l}\text { We assume most of these respondents were not present at formation } \\
\text { of the commune. Twenty-nine of the thirty-five answered the alternate } \\
\text { question. }\end{array}$
\end{tabular}


TABLE 59 .

SPECIFIC ISSUES RAISED AND SPEGIFIC DECISIONS MADE REGARDING SEX ROLES DURING THE FORMATIVE PERIOD ${ }^{1}$

\begin{tabular}{|c|c|c|c|c|c|c|c|c|}
\hline \multirow[b]{2}{*}{ Is sues } & \multicolumn{8}{|c|}{$\underline{\text { Decisions }}^{2}$} \\
\hline & + & 0 & - & $\theta$. & $\phi$ & $\phi$ & \multicolumn{2}{|c|}{ Tatal } \\
\hline General roles & $3 / 3$ & $1 / 2$ & $0 / 0$ & $0 / 0$ & $0 / 1$ & $0 / 1$ & $4 / 7$ & 11 \\
\hline Household responsibilities & $13 / 9$ & $0 / 0$ & $0 / 0$ & $2 / 1$ & $0 / 1$ & $1 / 0$ & $16 / 11$ & 27 \\
\hline Parenting & $1 / 1$ & $0 / 0$ & $0 / 0$ & $0 / 0$ & $0 / 0$ & $0 / 0$ & $1 / 1$ & 2 \\
\hline Employment & $1 / 2$ & $0 / 0$ & $0 / 0$ & $0 / 0$ & $0 / 0$ & $0 / 0$ & $1 / 2$ & 3 \\
\hline Women learning ... 3 & $3 / 4$ & $0 / 0$ & $0 / 0$ & $1 / 0$ & $0 / 0$ & $0 / 0$ & $4 / 4$ & 8 \\
\hline Emotional roles & $0 / 1$ & $0 / 0$ & $0 / 0$ & $0 / 0$ & $0 / 0$ & $0 / 0$ & $0 / 1$ & 1 \\
\hline Is sues not listed & $1 / 0$ & $1 / 1$ & $0 / 0$ & $0 / 0$ & $1 / 0$ & $0 / 0$ & $3 / 1$ & 4 \\
\hline Other & $0 / 1$ & $0 / 2$ & $0 / 0$ & $5 / 1$ & $0 \%$ & $4 / 0$ & $9 / 4$ & 13 \\
\hline Total. & $22 / 21$ & $2 / 5$ & $0 / 0$ & $8 / 2$ & $1 / 2$ & $5 / 1$ & $38 / 31$ & 69 \\
\hline Total & 43 & 7 & 0 & 10 & 3 & 6 & & 69 \\
\hline \multirow{2}{*}{\multicolumn{5}{|c|}{$\begin{array}{l}\text { 1. Female/Male indicates manner in which divided. } \\
\text { 2. Key for decisions } \\
+\begin{array}{l}\text { decision to break down traditional male/female } \\
\text { roles }\end{array}\end{array}$}} & \multicolumn{3}{|c|}{ No response $18 / 24$} & $\begin{array}{c}42^{4} \\
4\end{array}$ \\
\hline & & & & & \multicolumn{3}{|c|}{ Total } & $15^{5}$ \\
\hline \multicolumn{9}{|c|}{$\begin{array}{l}\text { - decision to reinforce traditional male/female roles } \\
\text { no decisions made } \\
\text { no decisions listed } \\
\text { 3. Women learning to do traditional male tasks. } \\
\text { 4. Many respondents were not present during formative period. } \\
\text { 5. Some respondents gave multiple answers. }\end{array}$} \\
\hline
\end{tabular}


TABLE 60

\section{FREQUENCY OF DISCUSSION OF SIMIIAR ISSUES}

How frequently
\begin{tabular}{|l|c|c|c|}
\hline Very often & 3 & 2 & 5 \\
\hline Fairly often & 5 & 5 & 10 \\
\hline Occasionally & 9 & 11 & 20 \\
\hline Rarcly & 16 & 9 & 25 \\
\hline Nover & 3 & 0 & 3 \\
\hline No response & 10 & 21 & 31 \\
\hline & & & $94 \mathrm{~N}$ \\
\hline Total & 46 & 48 & \\
\hline
\end{tabular}


TABLE 61

SPECIFIC ISSUES RAISED AND SPECIFIC DECISIONS MADE REGARDING SEX ROLES IN ONGOING MEETINGS ${ }^{1}$

\begin{tabular}{|c|c|c|c|c|c|c|c|c|}
\hline & & & $\mathrm{De}$ & sions & & & & \\
\hline Is sues & + & 0 & - & $\theta$ & b & $\not x$ & Tota & \\
\hline General roles & $1 / 1$ & $1 / 0$ & $0 / 0$ & $0 / 0$ & $0 / 1$ & $0 / 0$ & $2 / 2$ & 4 \\
\hline Hou sehold responsibilities & $6 / 3$ & $1 / 0$ & $0 / 0$ & $6 / 1$ & $0 / 1$ & $0 / 0$ & $13 / 5$ & 18 \\
\hline Parenting & $4 / 0$ & $0 / 0$ & $0 / 0$ & $0 / 0$ & $1 / 0$ & $0 / 0$ & $5 / 0$ & 5 \\
\hline Employment & $2 / 0$ & $0 / 0$ & $0 / 0$ & $1 / 0$ & $1 / 1$ & $0 / 0$ & $4 / 1$ & 5 \\
\hline Women learning .... ${ }^{3}$ & $1 / 1$ & $0 / 0$ & $0 / 0$ & $1 / 0^{\circ}$ & $1 \% 0$ & $0 / 0$ & $3 / 1$ & 4 \\
\hline Emotional roles & $1 / 3$ & $0 / 0$ & $0 / 0$ & $0 / 1$ & $0 / 2$ & $0 / 0$ & $1 / 6$ & 7 \\
\hline Issues not listed & $0 / 0$ & $0 / 0$ & $0 / 0$ & $1 / 1$ & $0 / 0$ & $0 / 0$ & $1 / 1$ & 2 \\
\hline Other & $0 / 0$ & $0 / 0$ & $0 / 0$ & $2 / 0$ & $0 / 1$ & $0 / 0$ & $2 / 1$ & 3 \\
\hline Total & $15 / 8$ & $2 / 0$ & $0 / 0$ & $11 / 3$ & $3 / 6$ & $0 / 0$ & $31 / 17$ & 48 \\
\hline Total & 23 & 2 & 0 & 14 & 9 & 0 & & 48 \\
\hline $\begin{array}{l}\text { 1. Female/Male indicates } \\
\text { 2. Key for decisions } \\
+ \text { decision to break do }\end{array}$ & $\begin{array}{l}\text { manne } \\
\text { wn tra }\end{array}$ & whi & $\begin{array}{l}\text { divid } \\
\text { ale/f }\end{array}$ & $\begin{array}{l}\text { d. } \\
\text { nale }\end{array}$ & $\begin{array}{l}\text { No } r \\
\text { Unce }\end{array}$ & ble & $4 / 30$ & $\begin{array}{r}544 \\
4\end{array}$ \\
\hline $\begin{array}{ll} & \text { roles } \\
0 & \text { neutral decision }\end{array}$ & & & & & Tota & & & \\
\hline $\begin{array}{l}\text { - decision to reinforce } \\
\theta \text { no decisions made } \\
\phi \text { no decisions listed } \\
\text { other } \\
\text { 3. Women learning to do tr } \\
\text { 4. Many respondents were } \\
\text { 5. Some respondents gave }\end{array}$ & $\begin{array}{l}\text { tradi } \\
\text { aditio } \\
\text { not pr } \\
\text { multip }\end{array}$ & al n & $\begin{array}{l}\text { sks } \\
\text { ng fo } \\
\text {. }\end{array}$ & ative & E1 & & & \\
\hline
\end{tabular}


TABLE 62

FREQUENCY OF DISCUSSION OF SEX ROLES

(RESPONDENTS WHO MOVED IN AFTER FORMATION OF COMMUNE)

\begin{tabular}{l} 
How frequently \\
\begin{tabular}{|l|c|c|c|}
\hline Very often & 2 & 2 & Total \\
\hline Fairly often & 1 & 1 & 4 \\
\hline Occasionally & 4 & 6 & 2 \\
\hline Rarely & 4 & 5 & 10 \\
\hline Never & 2 & 2 & 9 \\
\hline No response & 33 & 32 & 4 \\
\hline & & & $65^{1}$ \\
\hline Total & 46 & 48 & $94 \mathrm{~N}$ \\
\hline i. Most of those who did not respond were present during formative period \\
\hline
\end{tabular} \\
\hline
\end{tabular}


TABIE 63

SPECIFIC ISSUES RAISED AND SPECIFIC DECISIONS

MADE REGARDING SEX ROLES. IN ONGOING MEETINGS

( RESPONDENTS WHO MOVED IN AFTER FORMATION OF COMMUNE. )

\begin{tabular}{|c|c|c|c|c|c|c|c|c|}
\hline \multirow{2}{*}{ Is sues } & \multicolumn{8}{|c|}{ Decisions 2} \\
\hline & + & 0 & \multicolumn{2}{|c|}{$-\frac{\theta}{\theta}$} & $\phi$ & $x$ & \multicolumn{2}{|c|}{ Total } \\
\hline General roles & $0 / 1$ & $1 / 0$ & $0 \%$ & $0 / 1$ & $0 / 0$ & $0 / 0$ & $1 / 2$ & 3 \\
\hline Household responsibilities & $2 / 5$ & $0 / 0$ & $0 / 1$ & $0 / 1$ & $1 / 0$ & $0 / 0$ & $3 / 7$ & 10 \\
\hline Parenting & $0 / 0$ & $0 / 0$ & $0 / 1$ & $0 / 0$ & $1 / 0$ & $0 / 0$ & $1 / 1$ & 2 \\
\hline Employment & $0 / 0$ & $0 / 0$ & $0 / 0$ & $0 / 1$ & $0 / 1$ & $0 / 0$ & $0 / 2$ & 2 \\
\hline Women learning ... 3 & $1 / 0$ & $1 / 0$ & $0 / 0$ & $0 / 1$ & $0 / 0$ & $0 / 0$ & $2 / 1$ & 3 \\
\hline Emotional roles & $0 / 1$ & $0 / 0$ & $0 / 0$ & $0 / 0$ & $0 / 1$ & $0 / 0$ & $0 / 2$ & 2 \\
\hline Issues not listed. & $0 / 0$ & $1 / 0$ & $0 / 0$ & $0 / 0$ & $0 / 0$ & $0 / 0$ & $1 / 0$ & 1 \\
\hline Other & $0 / 0$ & $0 / 0$ & $0 / 0$ & $3 / 1$ & $0 / 0$ & $0 / 0$ & $3 / 1$ & 4 \\
\hline Total & $3 / 7$ & $3 / 0$ & $0 / 2$ & $3 / 5$ & $2 / 2$ & $0 / 0$ & $11 / 16$ & 27. \\
\hline Total & 10 & 3 & 2 & 8 & 4 & 0 & & 27 \\
\hline \multirow{2}{*}{\multicolumn{5}{|c|}{$\begin{array}{l}\text { 1. Female/Male indicates manner in which divided. } \\
\text { 2. } \frac{\text { Key for decisions }}{+ \text { decision to break down traditional male/female }} \\
\text { roles } \\
0 \text { neutral decision }\end{array}$}} & $\begin{array}{l}\text { No re } \\
\text { Unco }\end{array}$ & $\begin{array}{l}\text { bonse } \\
\text { ble }\end{array}$ & $\begin{array}{l}42 / 33 \\
1 / 1 \\
\end{array}$ & $\begin{array}{l}75^{4} \\
2 \\
\end{array}$ \\
\hline & & & & & \multicolumn{2}{|l|}{ Total } & \multicolumn{2}{|c|}{$104^{5}$} \\
\hline \multicolumn{9}{|c|}{$\begin{array}{l}\text { - decision to reinforce traditional male/female roles } \\
\text { no decisions made } \\
\text { no decisions listed } \\
\text { 3. Womer learning to do traditional male tasks. } \\
\text { 4. Many respondents were not present during formative period. } \\
\text { 5. Some respondents gave multiple answers. }\end{array}$} \\
\hline
\end{tabular}


TABLE 64

LEVEL OF SATISFACTION WITH DECISIONS REGARDING SEX ROLES

\begin{tabular}{|l|c|c|c|}
\hline Level of satisfaction & Women & Men & Total \\
\hline Very dissatisfied (1) & 1 & 0 & 1 \\
\hline$(2)$ & 4 & 1 & 5 \\
\hline$(3)$ & 2 & 5 & 7 \\
\hline$(4)$ & 11 & 13 & 24 \\
\hline Very satisfied (5) & 16 & 14 & 30 \\
\hline No response & 12 & 15 & 27 \\
\hline Total & 4 & & $94 \mathrm{~N}$ \\
\hline
\end{tabular}

TABLE 65

NUMBER OF SATISFACTIONS AND DISSATISFACTIONS IISTED REGARDING DECISIONS

Number of satisfactions and dissatisfactions

\begin{tabular}{|c|c|c|}
\hline Women & Men & Total \\
\hline 38 & 31 & 69 \\
\hline 19 & 8 & 27 \\
\hline 14 & 16 & 301 \\
\hline 0 & 4 & 4 \\
\hline 71 & 59 & $130^{2}$ \\
\hline
\end{tabular}

1. Most of those who did not respond saw no decisions as having been made.

2. Several respondents listed more than one satisfaction and/or dissatisfaction. Eleven men and nine women listed both a satisfaction and a dissatisfaction. 
TABLE 66

EXTENT TO WHICH RESPONDENTS FEEL GROUP DECISIONS

REGARDING SEX ROLES HAVE BECOME REALITY

\begin{tabular}{|c|c|c|c|}
\hline Extent & Women & Men & Total \\
\hline Not at all (1) & 0 & 0 & 0 \\
\hline$(2)$ & 2 & 3 & 5 \\
\hline$\cdot(3)$ & 2 & 3 & 5 \\
\hline (4) & 10 & 12 & 22 \\
\hline Very much (5) & 12 & 8 & 20 \\
\hline No response & 20 & 22 & $42^{1}$ \\
\hline Total & 46 & 48 & 94 \\
\hline \multicolumn{4}{|c|}{$\begin{array}{l}\text { 1. Most of those who did not respond saw no decisions as having } \\
\text { been made. }\end{array}$} \\
\hline
\end{tabular}


TABLE 67

PERCEPTIONS OF WHAT FACTORS AIDED PROCESS

OF GROUP DECISIONS BECOMING REALITY

\begin{tabular}{|c|c|c|c|}
\hline Factors & Women & Men & Total \\
\hline Strong leadership & 0 & 1 & 1 \\
\hline Ideology & 0 & 1 & 1 \\
\hline Commitment & 8 & 4 & 12 \\
\hline Interpersonal support & 10 & 4 & 14 \\
\hline Specific awareness training & 2 & 1 & 3 \\
\hline Group expectations or agreement & 9 & 8 & 17 \\
\hline Commonality of group members & 0 & 2 & 2 \\
\hline Personal growth and maturation & 0 & 0 & 0 \\
\hline Other & 8 & 10 & 18 \\
\hline No response & 19 & 22 & $41^{1}$ \\
\hline Uncodable & 1 & 1 & 2 \\
\hline Total & 57 & 54 & $111^{2}$ \\
\hline \multicolumn{4}{|c|}{$\begin{array}{l}\text { 1. Most of those who did not respond saw no decisions as having } \\
\text { been made. } \\
\text { 2. Multiple answers were given in a few cases. }\end{array}$} \\
\hline
\end{tabular}


TABLE 68

PLRCLPTIONS OF WHAT FACTORS HINDERED THE PROCESS OF GROUP DECISIONS BECOMING REA LITY

\begin{tabular}{|c|c|c|c|}
\hline Factors & Women & Men & Tota l \\
\hline Previous life experience & 8 & 8 & 16 \\
\hline Social pressure & 0 & 0 & 0 \\
\hline Social structure & 1 & 1 & 2 \\
\hline Lack of commitment & 1 & 0 & 1 \\
\hline Internal differences of opinion & 1 & 2 & 3 \\
\hline Internal practical difficulties & 4 & 4 & 8 \\
\hline Other & 7 & 7 & 14 \\
\hline No response. & 24 & 30 & $54^{1}$ \\
\hline Uncodable & 2 & 0 & 2 \\
\hline Total & 48 & 52 & $100^{2}$ \\
\hline \multicolumn{4}{|c|}{$\begin{array}{l}\text { 1: Most of those who did not respond saw no decisions as having } \\
\text { been made. } \\
\text { 2. Multiple answers were given in a few cases. }\end{array}$} \\
\hline
\end{tabular}


LEVEL OF SATISEACTION WITH DEVELOPMENT OF SEX ROLES, (WHERE NO DECISIONS WERE MADE)

Level of satisfaction

Women

Men

Total

\begin{tabular}{|c|c|c|c|}
\hline Very dissątisfied (1) & 0 & 0 & 0 \\
\hline (2) & 4 & 0 & 4 \\
\hline$(3)$ & 5 & 6 & 11 \\
\hline (4) & 7 & 6 & 13 \\
\hline Vory satisficd (5) & 4 & 6 & 10 \\
\hline No response & 26 & 30 & $56^{1}$ \\
\hline & 46 & 48 & 94 \\
\hline $\begin{array}{l}\text { Total } \\
\text { 1. Most of those who did not respond to this question, responded to } \\
\text { the alternative question where decisions had been made. }\end{array}$ \\
\hline
\end{tabular}

TABLE 70

NUMBER OF SATISFACTIONS AND DISSATISFACTIONS LISTED

REGARDING DEVELOPMENT OF SEX ROLES

(WHERE NO DECISIONS WERE MADE)

Number of satisfactions and dissatisfactions

Women

Men

Total

\begin{tabular}{|l|r|r|c|}
\hline Satisfaction & 11 & 10 & 21 \\
\hline Dissatisfaction & 9 & 4 & 13 \\
\hline No response & 33 & 34 & 671 \\
\hline Uncodablo & 1 & 2 & 3 \\
\hline Total & 54 & 50 & $104^{2}$ \\
\hline
\end{tabular}

1. Most of those who did not respond saw decisions as having been made

2. A few respondents listed more than one satisfaction and/or dissatisfaction. T'wo men and four women listed both a satisfaction and a dissatisfaction . 
TABLE 71

PERCEPTIONS OF WHETHER OR NOT COMMUNES

POTENTIALLY HAVE A UNIQUE INFLUENCE ON DEVELOPMENT OF SEX ROLES IN THE LARGER SOCIETY

Whether or not

\begin{tabular}{|c|c|c|}
\hline Women & Men & Total \\
\hline 38 & 37 & 75 \\
\hline 4 & 8 & 12 \\
\hline 7 & 3 & 10 \\
\hline $49^{1}$ & 48 & $97^{1}$ \\
\hline
\end{tabular}

1. Three women answered both yes and no.

TABLE 72

PERCEPTIONS OF HOW COMMUNES POTENTIALLY HAVE A UNIQUE INFLUENCE ON THE DEVELOPMENT OF SEX ROLES IN THE LARGER SOCIETY

\begin{tabular}{|c|c|c|c|}
\hline Perceptions of how & Women & Men & Total \\
\hline Not specified & 8 & 7 & 15 \\
\hline As o model & 7 & 7 & 14 \\
\hline Personal influence & 3 & 2 & 5 \\
\hline Children who grow up there & 3 & 0 & 3 \\
\hline As an alternative & 19 & 17 & 36 \\
\hline Other & 5 & 0 & 5 \\
\hline No response & 3 & 1.4 & 17 \\
\hline Uncodable & 4 & 1 & 5 \\
\hline Total & 52 & 48 & Ino \\
\hline
\end{tabular}


WHAT KINDS OF DIFFERENCES

(IN WHAT AREAS AND IN WHAT DIRECTION) RESPONDLNTS EXPECTED IN SEX ROLES FROM THE TRADITIONAL NUCLEAR FAMILY ${ }^{l}$

Direction ${ }^{2}$

\begin{tabular}{|c|c|c|c|c|c|}
\hline Area & + & 0 & - & & tal \\
\hline General roles & $9 / 22$ & $1 / 1$ & $0 / 0$ & $10 / 23$ & 33 \\
\hline Household responsibilities & $30 / 11$ & $0 / 0$ & $1 / 0$ & $31 / 11$ & 42 \\
\hline Parenting & $9 / 4$ & $0 / 0$ & $0 / 0$ & $9 / 4$ & 13 \\
\hline Employment & $7 / 2$ & $0 / 0$ & $0 / 0$ & $7 / 2$ & 9 \\
\hline Women learning ...3 & $9 / 2$ & $0 / 0$ & $0 / 0$ & $9 / 2$ & 11 \\
\hline Emotional roles & $3 / 2$ & $0 / 0$ & $0 / 0$ & $3 / 2$ & 5 \\
\hline Decision - making & $5 / 2$ & $0 / 0$ & $1 / 0$ & $6 / 2$ & 8 \\
\hline Sexual behavior & $6 / 2$ & $0 / 0$ & $0 / 0$ & $6 / 2$ & 8 \\
\hline Cross - sexual friend ships & $2 / 1$ & $0 / 0$ & $0 \%$ & $2 / 1$ & 3 \\
\hline Other & $1 / 1$ & $2 / 2$ & $0 / 2$ & $3 / 5$ & 8 \\
\hline & $81 / 49$ & $3 / 3$ & $2 / 2$ & $86 / 54$ & 140 \\
\hline Total & 130 & 6 & 4 & $=140$ & \\
\hline & & & \multicolumn{2}{|c|}{ No response } & $\frac{13}{153^{4}}$ \\
\hline \multicolumn{6}{|c|}{ 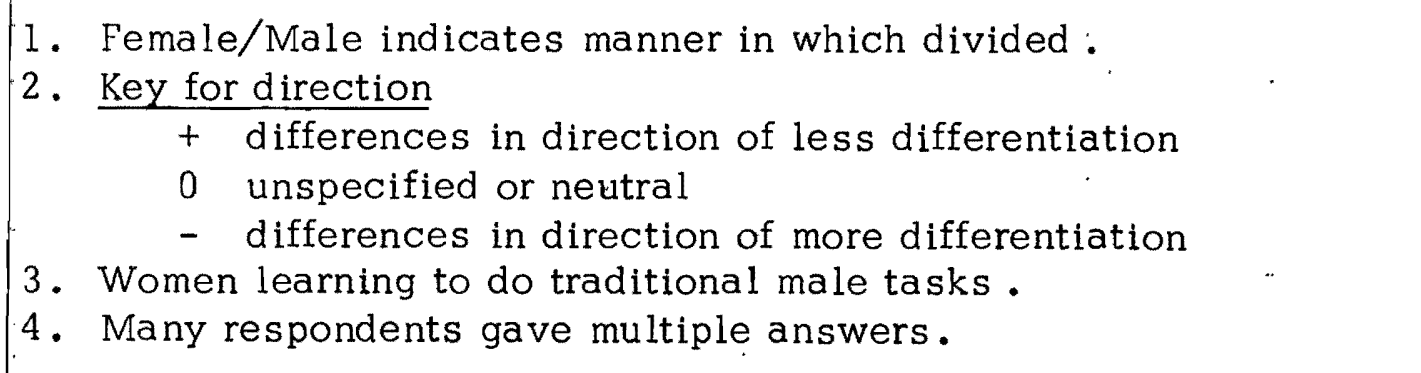 } \\
\hline
\end{tabular}


INABI.1: 71

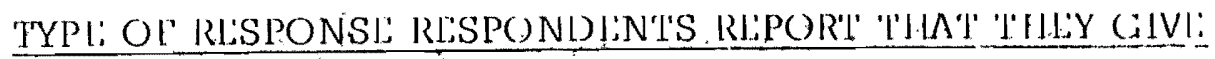

IN SITUATIONS WHERE CONFLICT

EXISTS BETWEEN THE LARGER SOCIETY

AND THEIR VALUES REGARDING SEX ROLES

\begin{tabular}{|c|c|c|c|}
\hline Type of response & Women & Men & Total \\
\hline Assertive & 13 & 13 & 26 \\
\hline Aggressive & 7 & 4 & 11 \\
\hline Passive - withdrawal & 14 & 12 & 26 \\
\hline Passive - acceptance & 1 & 5 & 6 \\
\hline Not a problem & 7 & 4 & 11 \\
\hline Other & 2 & 8 & 10 \\
\hline No response & 8 & 11 & 19 \\
\hline Uncodable & 3 & 1 & 4 \\
\hline Total & 55 & 58 & $113^{1}$ \\
\hline \multicolumn{4}{|c|}{$\begin{array}{l}\text { 1. Several respondents listed more than one response depending on the } \\
\text { type of conflict. }\end{array}$} \\
\hline
\end{tabular}

\section{TABLE 75}

WHETHER OR NOT RESPONDENTS REPORT THEIR IDEALS REGARDING SEX ROLES HAVE CHANGED AS A RESULT OF COMMUNAL LIVING

\begin{tabular}{|} 
Whether or not \\
\hline Yes & Women & Men & Total \\
\hline No & 20 & 17 & 37 \\
\hline No response & 21 & 21 & 42 \\
\hline & 5 & 10 & 15 \\
Total & & & \\
\hline
\end{tabular}


I'ABSIL: 76

\section{NATURE OF CHANGES IN IDEALS REGARDING SEX ROLES}

\begin{tabular}{|l|c|c|c|} 
Nature of changes & Women & Men & Total \\
\hline More equal & 12 & 11 & 23 \\
\hline Less equal & 0 & 0 & 0 \\
\hline Ideal more realistic & 2 & 1 & 3 \\
\hline Other & 1 & 3 & 4 \\
\hline No response & 27 & 27 & 54 \\
\hline Uncodable & 4 & 6 & 10 \\
\hline & & & $94 \mathrm{~N}$ \\
\hline Total & 46 & 48 & \\
\hline
\end{tabular}

I. Most of those who did not respond did not see their ideals as having changed. 
TABLE 77

PIRCLPTIONS OP WHAT LED TO CHANGES IN

IDEALS REGARDING SEX ROLES

\begin{tabular}{|c|c|c|c|}
\hline What led to changes & Women & Men & Total \\
\hline Strong leadership & 0 & 0 & 0 \\
\hline Ideology & 0 & 1 & 1 \\
\hline Commitment & 0 & 1 & 1 \\
\hline Interpersonal support & 4 & 5 & 9 \\
\hline Specific awareness training & 0 & 1 & 1 \\
\hline Group expectation and/or agree & 3 & 2 & 5 \\
\hline Commonality of group members & 1 & 0 & 1 \\
\hline Personal growth and maturation & 6 & 6 & 12 \\
\hline Other & 6 & 4 & 10 \\
\hline No response & 33 & 27 & 601 \\
\hline Uncodable & 0 & 2 & 2 \\
\hline Total & 53 & 49 & $102^{2}$ \\
\hline
\end{tabular}

1. Most of those who did not respond did not see their ideals as having changed.

2. Multiple answers were given in a few cases. 
TABLE 78

DEGREE OF STRUCTURE IN METHOD OF TASK ASSIGNMENT 1

$\underline{\text { Degree of structure }}{ }^{2}$

Commune $^{4} \begin{aligned} & \text { More } \\ & \text { structure }^{3}\end{aligned} \begin{aligned} & \text { Less } \\ & \text { structure Consensus Other response Total }\end{aligned}$

\begin{tabular}{|c|c|c|c|c|c|c|}
\hline 1 & $3 / 6$ & $60 / 41$ & $1 / 0$ & $12 / 10$ & $16 / 0$ & $92 / 57$ \\
\hline 2 & $10 / 8$ & $22 / 33$ & $0 / 0$ & $7 / 5$ & $14 / 11$ & $53 / 57$ \\
\hline 3 & $0 / 8$ & $10 / 31$ & $4 / 10$ & $0 / 9$ & $5 / 22$ & $19 / 80$ \\
\hline 4 & $9 / 0$ & $29 / 0$ & $0 / 0$ & $1 / 0$ & $16 / 0$ & $55 / 0$ \\
\hline 5 & $7 / 5$ & $18 / 33$ & $0 / 1$ & $1 / 5$ & $14 / 16$ & $40 / 60$ \\
\hline 6 & $5 / 9$ & $4 / 11$ & $0 / 2$ & $5 / 18$ & $6 / 20$ & $20 / 60$ \\
\hline 8 & $7 / 4$ & $15 / 31$ & $0 / 0$ & $7 / 0$ & $11 / 5$ & $40 / 40$ \\
\hline 9 & $17 / 9$ & $12 / 12$ & $1 / 0$ & $12 / 13$ & $18 / 6$ & $60 / 40$ \\
\hline 10 & $3 / 3$ & $16 / 16$ & $0 / 0$ & $6 / 2$ & $15 / 19$ & $40 / 40$ \\
\hline 11 & $12 / 7$ & $16 / 3$ & $0 / 0$ & $4 / 5$ & $28 / 5$ & $60 / 20$ \\
\hline 12 & $23 / 47$ & $47 / 64$ & $16 / 13$ & $2 / 11$ & $8 / 46$ & $96 / 181$ \\
\hline 13 & $6 / 4$ & $17 / 26$ & $1 / 1$ & $1 / 0$ & $15 / 45$ & $40 / 76$ \\
\hline 14 & $4 / 1$ & $42 / 8$ & $5 / 2$ & $15 / 0$ & $34 / 9$ & $100 / 20$ \\
\hline 15 & $2 / 6$ & $34 / 44$ & $0 / 0$ & $4 / 22$ & $0 / 8$ & $40 / 80$ \\
\hline 16 & $7 / 8$ & $5 / 15$ & $1 / 3$ & $2 / 0$ & $5 / 11$ & $20 / 37$ \\
\hline 17 & $3 / 0$ & $44 / 0$ & $0 / 0$ & $8 / 0$ & $4 / 0$ & $59 / 0$ \\
\hline 18 & $11 / 15$ & $7 / 8$ & $0 / 0$ & $2 / 2$ & $20 / 12$ & $40 / 37$ \\
\hline 19 & $10 / 15$ & $13 / 9$ & $0 / 0$ & $3 / 6$ & $12 / 10$ & $38 / 40$ \\
\hline \multicolumn{7}{|c|}{$\begin{array}{l}\text { 1. Women/Men indicates manner in which divided. } \\
\text { 2. See Appendix E p. } 135 \text {. } \\
\text { 3. This table is a composite and does not list tasks separately as Tables } 87-104 \\
\text { 4. As previously stated commune \# } 7 \text { did not fill out questionnaire. }\end{array}$} \\
\hline
\end{tabular}


TABLE 79

WHETHER OR NOT THE PATTERN OF RESPONSIBILITY FOR ACTIVITIES LISTED ON THE GRID (QUESTION 21) HAS CHANGED OVER TIME

\begin{tabular}{|c|c|c|c|}
\hline Whether or not & Women & Men & Total \\
\hline Yes & 17 & 21 & 38 \\
\hline No & 18 & 11 & 29 \\
\hline No response & 11 & 16 & 27 \\
\hline Total & 46 & 48 & $94 \mathrm{~N}$ \\
\hline
\end{tabular}

TABLE 80

HOW THE RESPONSIBILITY FOR THOSE ACTIVITIES LISTED ON THE GRID (QUESTION 21) HAS CHANGED OVER TIME (IF IT HAS CHANGED) )

How 1 Women Men Total

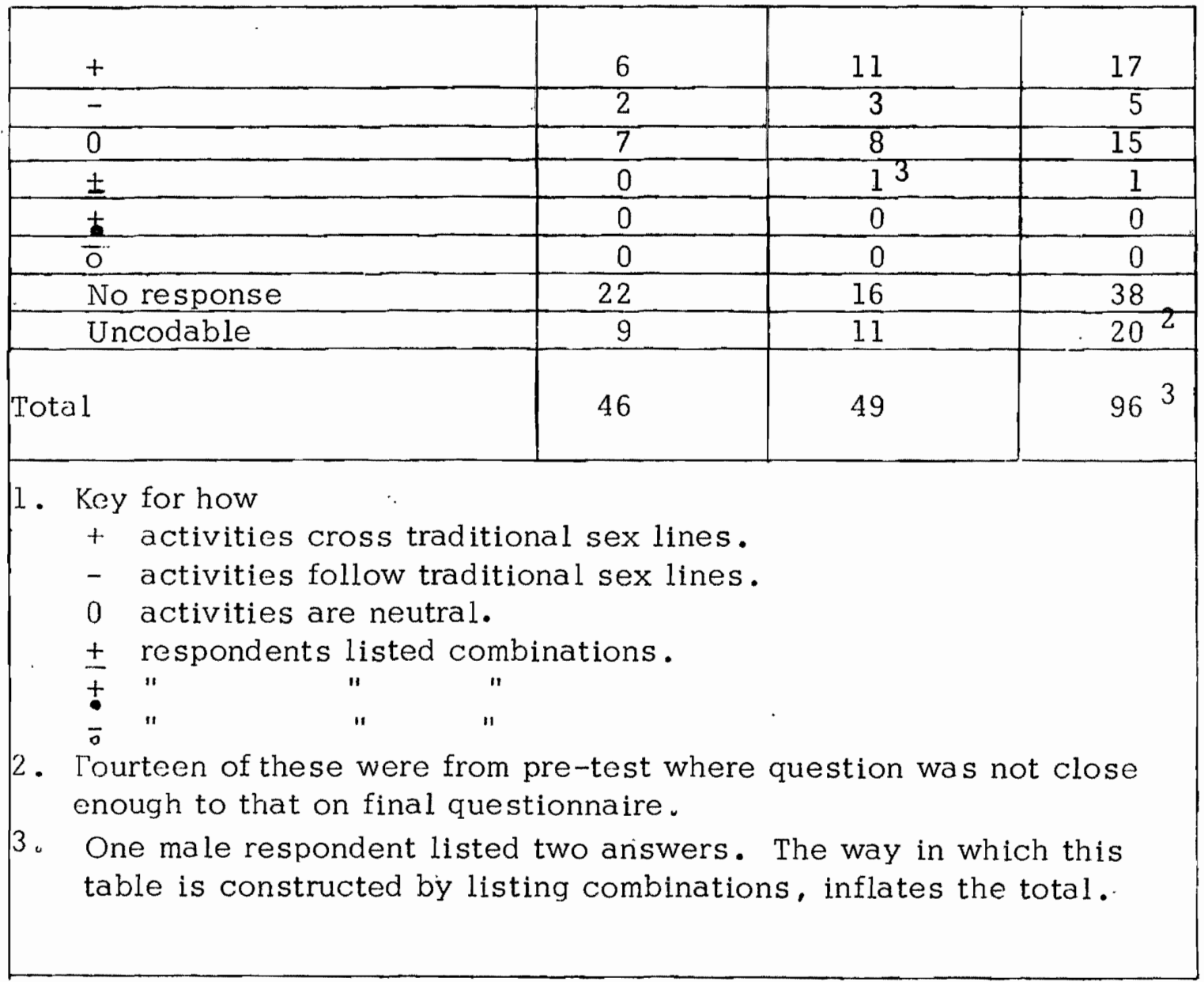


TAB LI: 81

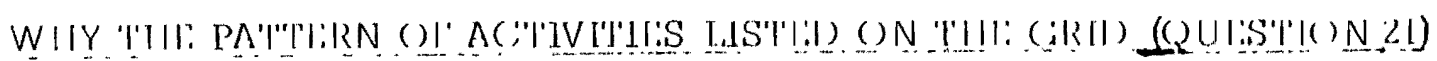
HAS CHANGLD OVER TIML (IF II HAS CHANGLD)

\begin{tabular}{|c|c|c|c|}
\hline Why & Women & Men & Total \\
\hline Could not get cooperation & 0 & 0 & 0 \\
\hline Individual preferences & 5 & 2 & 7 \\
\hline Changing needs of commune & 0 & 0 & 0 \\
\hline Changing philosophy of commune & 0 & 0 & 0 \\
\hline Practical considerations & 3 & 4 & 7 \\
\hline Consciousness of group & 1 & 4 & 5 \\
\hline Other & $I$ & 2 & 3 \\
\hline Not specified 1 & 8 & 8 & 16 \\
\hline No response 2 & 27 & 25 & 52 \\
\hline Uncodable & 2 & 4 & 6 \\
\hline Total & 47 & 49 & $96^{3}$ \\
\hline $\begin{array}{l}\text { 1. Listed a change but did not } \\
\text { 2. Listed no change at all. } \\
\text { 3. Two respondents listed two re }\end{array}$ & $\begin{array}{l}\text { ecify. } \\
\text { asons. }\end{array}$ & & \\
\hline
\end{tabular}


DIRECTION OF NEW ACTIVITIES DONE SINCE JOINING THE COMMUNE.

\begin{tabular}{|c|c|c|c|}
\hline Direction ${ }^{1}$ & Women & Men & Total \\
\hline+ & 25 & 23 & 48 \\
\hline- & 12 & 11 & 23 \\
\hline 0 & 15 & 18 & 33 \\
\hline \pm & 10 & 6 & 16 \\
\hline$\stackrel{+}{0}$ & 2 & 3 & 5 \\
\hline$\overline{0}$ & 1 & 2 & 3 \\
\hline No response & 7 & 6 & 13 \\
\hline Uncodable & 1 & 1 & 2 \\
\hline Total & 73 & 70 & $143^{2}$ \\
\hline \multicolumn{4}{|c|}{$\begin{array}{l}\text { 1. Key for direction } \\
\frac{+ \text { activities cross traditional sex lines. }}{0 \text { activities are neutral. }} \\
- \text { activities follow traditional sex lines. } \\
\pm \text { Respondents listed combinations. } \\
\text { 2. Several respondents listed more than one answer. In addition the } \\
\text { way this table is constructed, by listing combinations, inflates } \\
\text { the total. }\end{array}$} \\
\hline
\end{tabular}


TABLE 83

LEVEL OF SATISFACTION WITH DECISIONS REGARDING SEX ROLES (WITH CATEGORIES COLIAPSED)

\begin{tabular}{|l|c|c|c|}
\hline Level of satisfaction & Women & Men & Total \\
\hline Very satisfied (4)-(5) & 27 & 27 & 54 \\
\hline Very dissatisfied (1)-(3) & 7 & 6 & 13 \\
\hline Total & 34 & 33 & 67 \\
\hline
\end{tabular}

TABLE 84

LEVEL OF SATISFACTION WITH DEVELOPMENT OF SEX ROLES (WHERE NO DECISIONS WERE MADE) (WITH CATEGORIES COLLAPSED)

\begin{tabular}{|l|c|c|c|}
\hline Level of satisfaction & Women & Men & Total \\
\hline Very satisfied (4)- (5) & 11 & 12 & 23 \\
\hline Very dissatisfied (1)-(3) & 9 & 6 & 15 \\
\hline \begin{tabular}{l} 
Total \\
\hline
\end{tabular} & 20 & 18 & 38 \\
\hline
\end{tabular}


TABLE 85

LEVEL OF SATISFACTION WITH DECISIONS REGARDING SEX ROLES BY PERCENTAGES OF THOSE WHO RESPONDED

\begin{tabular}{|c|r|r|} 
Level of satisfaction & Women & Men \\
\hline Very dissatisfied (1) & $3 \%(1)$ & $0 \% \quad(0)$ \\
\hline$(2)$ & $12 \%(4)$ & $3 \%(1)$ \\
\hline$(3)$ & $6 \%(2)$ & $15 \% \quad(5)$ \\
\hline$(4)$ & $32 \%(11)$ & $40 \% \quad(13)$ \\
\hline Very satisfied (5) & $47 \%(16)$ & $42 \% \quad(14)$ \\
\hline Total & $100 \% \quad(34)$ & $100 \% \quad(33)$ \\
\hline
\end{tabular}

TABLE 86

LEVEL OF SATISFACTION WITH DEVELOPMENT OF SEX ROLES (WHERE NO DECISIONS WERE MADE) BY PERCENTAGES OF THOSE WHO RESPONDED

\begin{tabular}{|c|c|c|}
\hline Level of satisfaction & Women & Men \\
\hline Very dissatisfied (1) & $0 \% \quad(0)$ & $0 \% \quad(0)$ \\
\hline$(2)$ & $20 \% \quad(4)$ & $0 \% \quad(0)$ \\
\hline$(3)$ & $25 \% \quad(5)$ & $33 \% \quad(6)$ \\
\hline (4) & $35 \% \quad(7)$ & $33 \% \quad(6)$ \\
\hline Very satisfied (5) & $20 \% \quad(4)$ & $33 \% \quad(6)$ \\
\hline Total & $100 \% \quad(20)$ & $99 \%(18)^{1}$ \\
\hline 1. Each was actually & $\%$. & \\
\hline
\end{tabular}




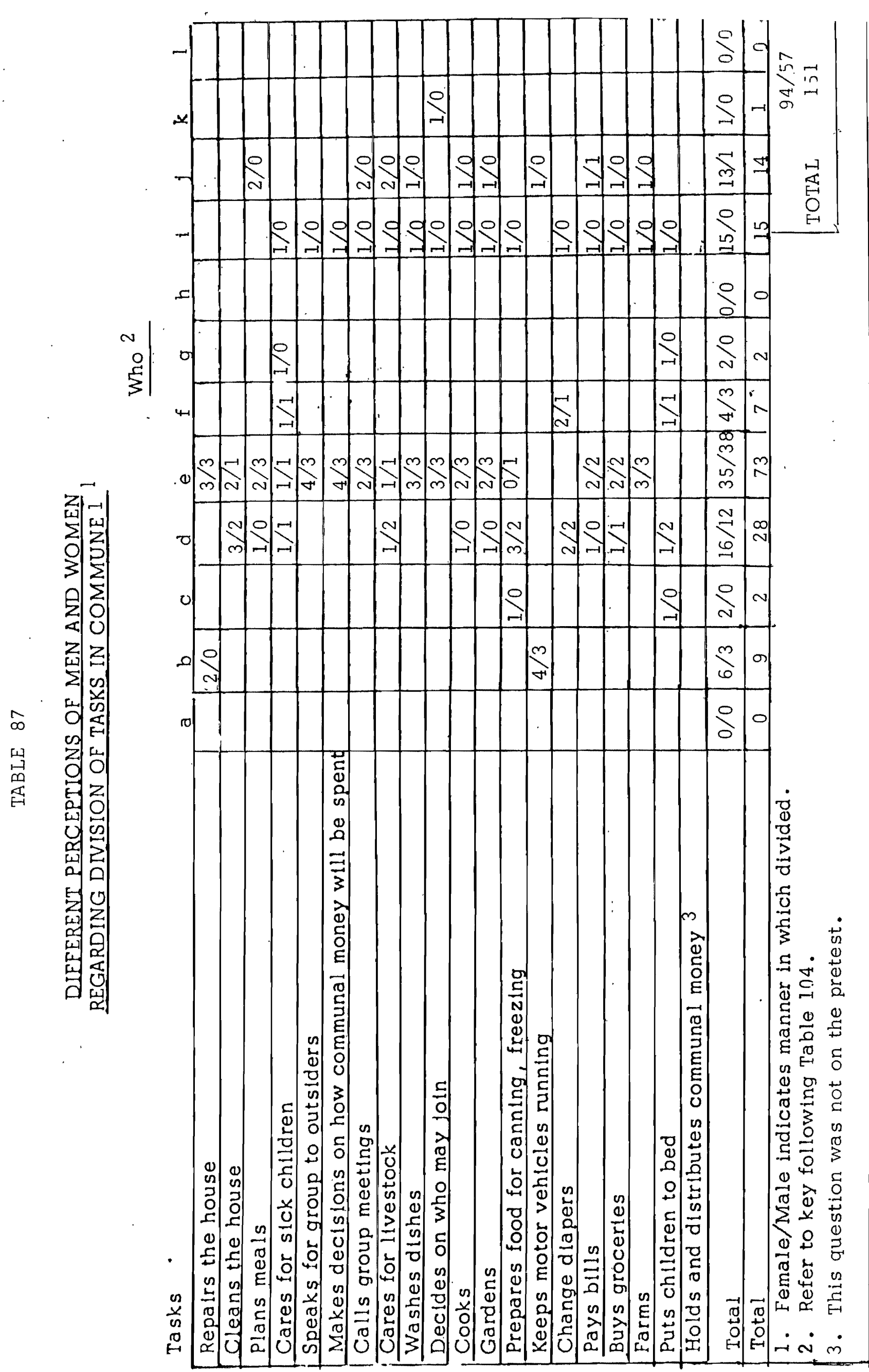




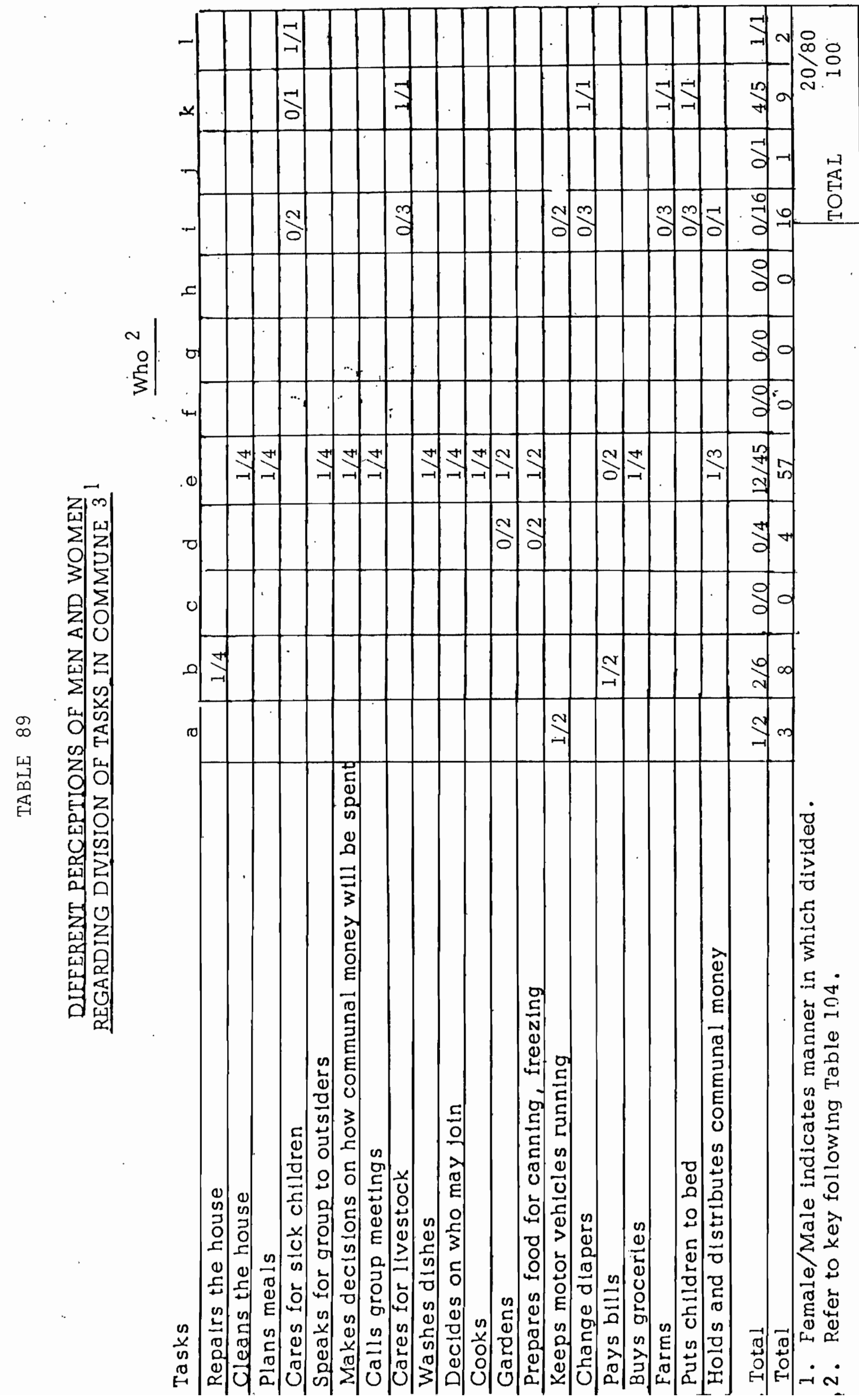




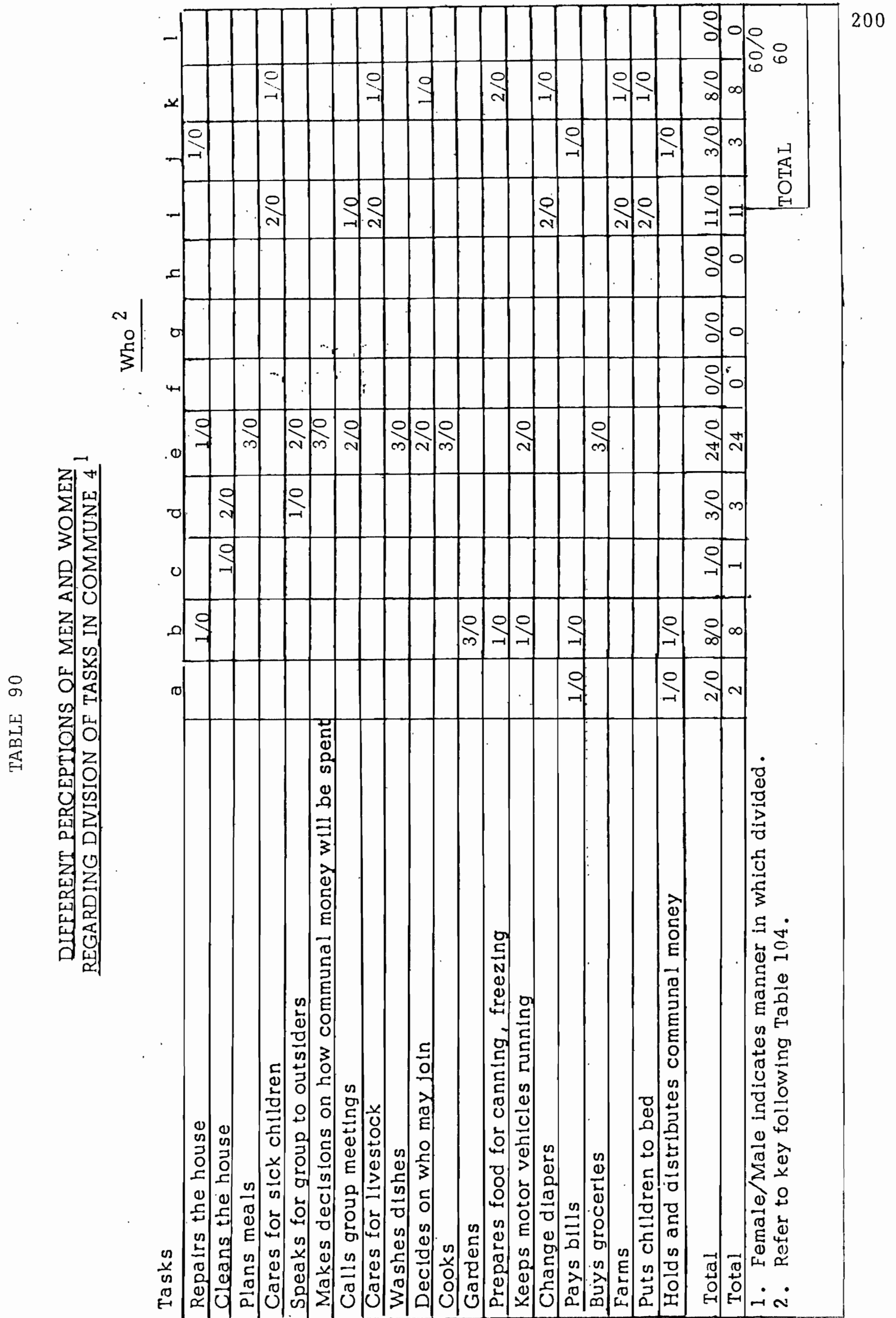




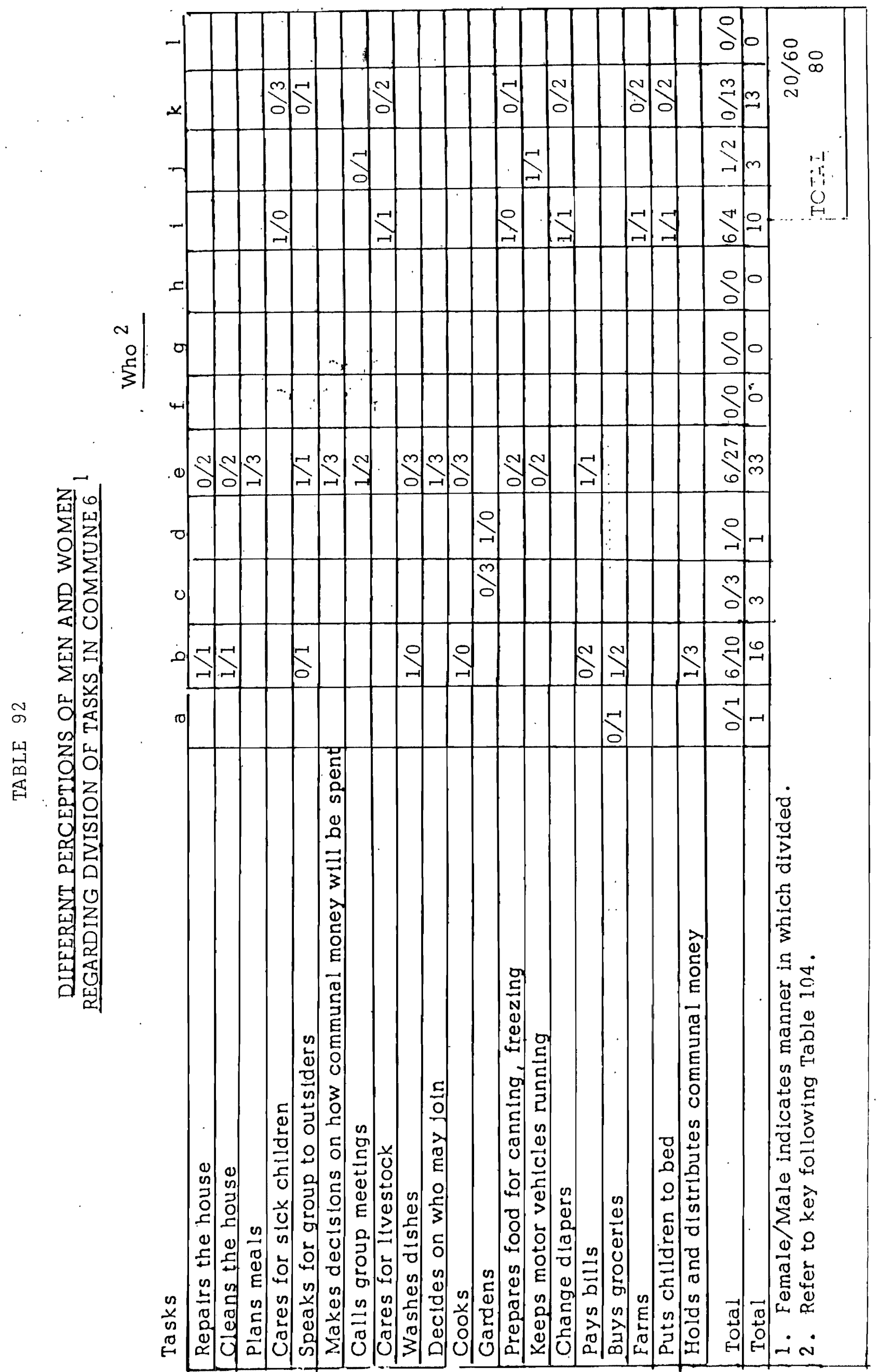




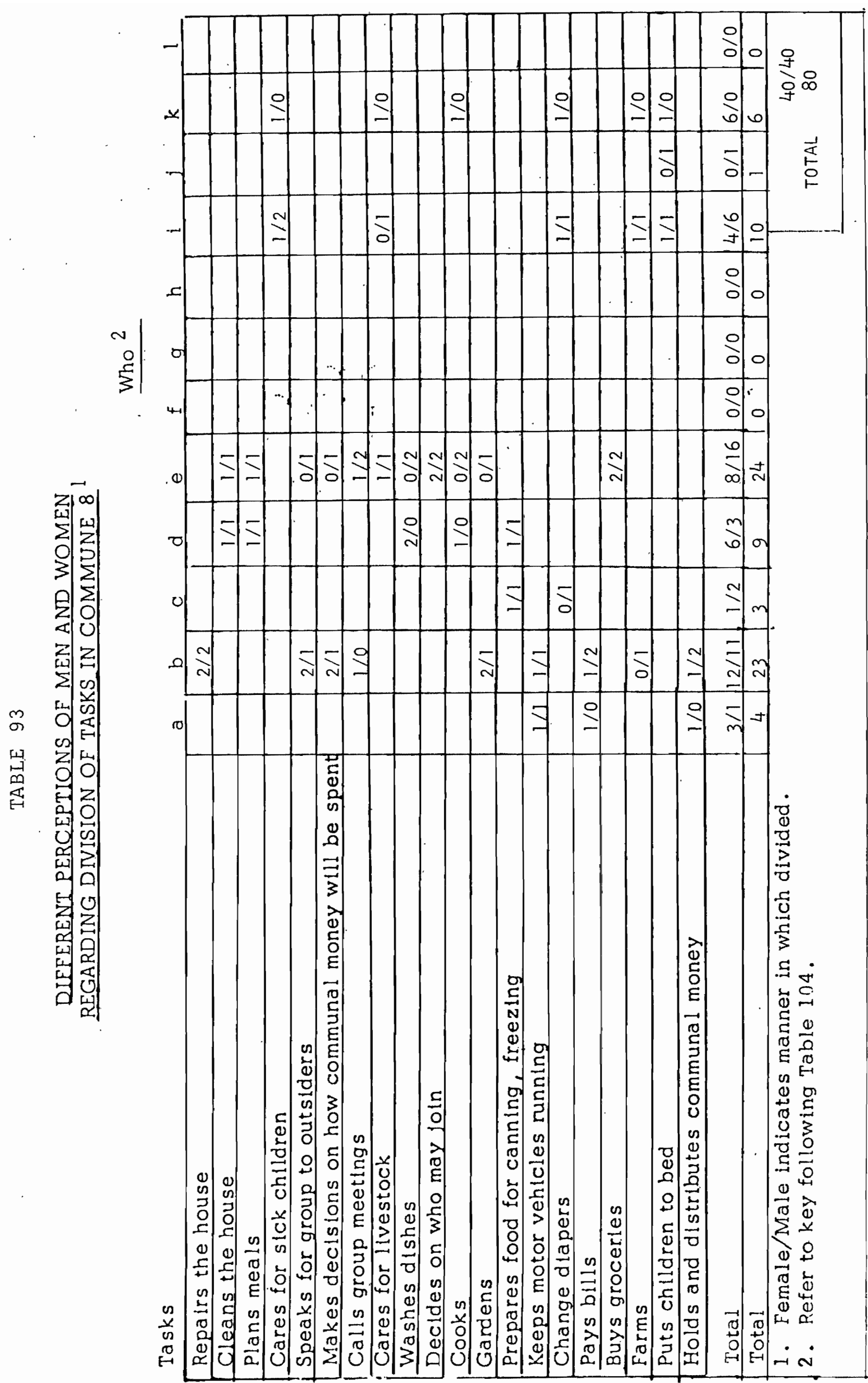




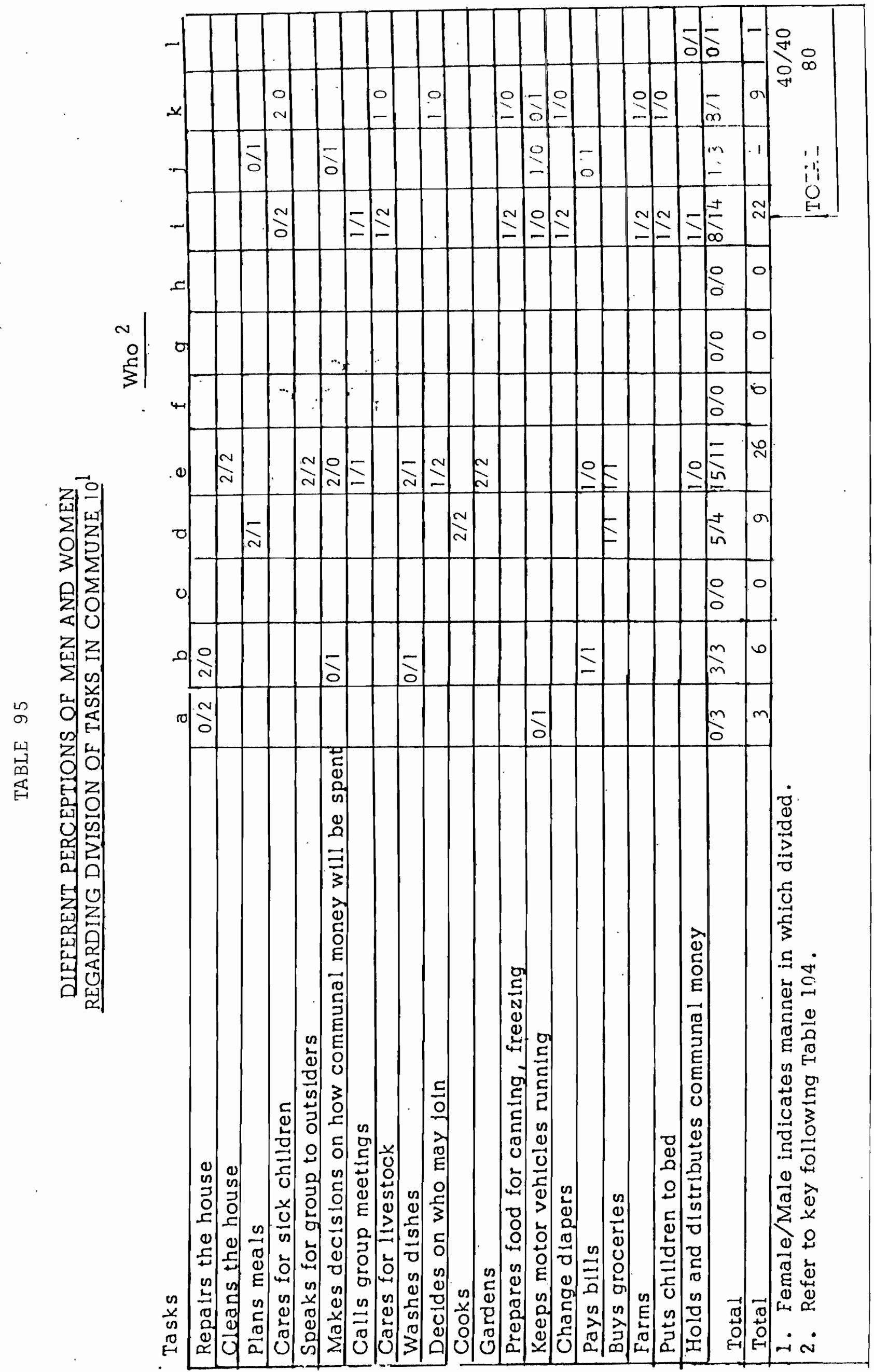




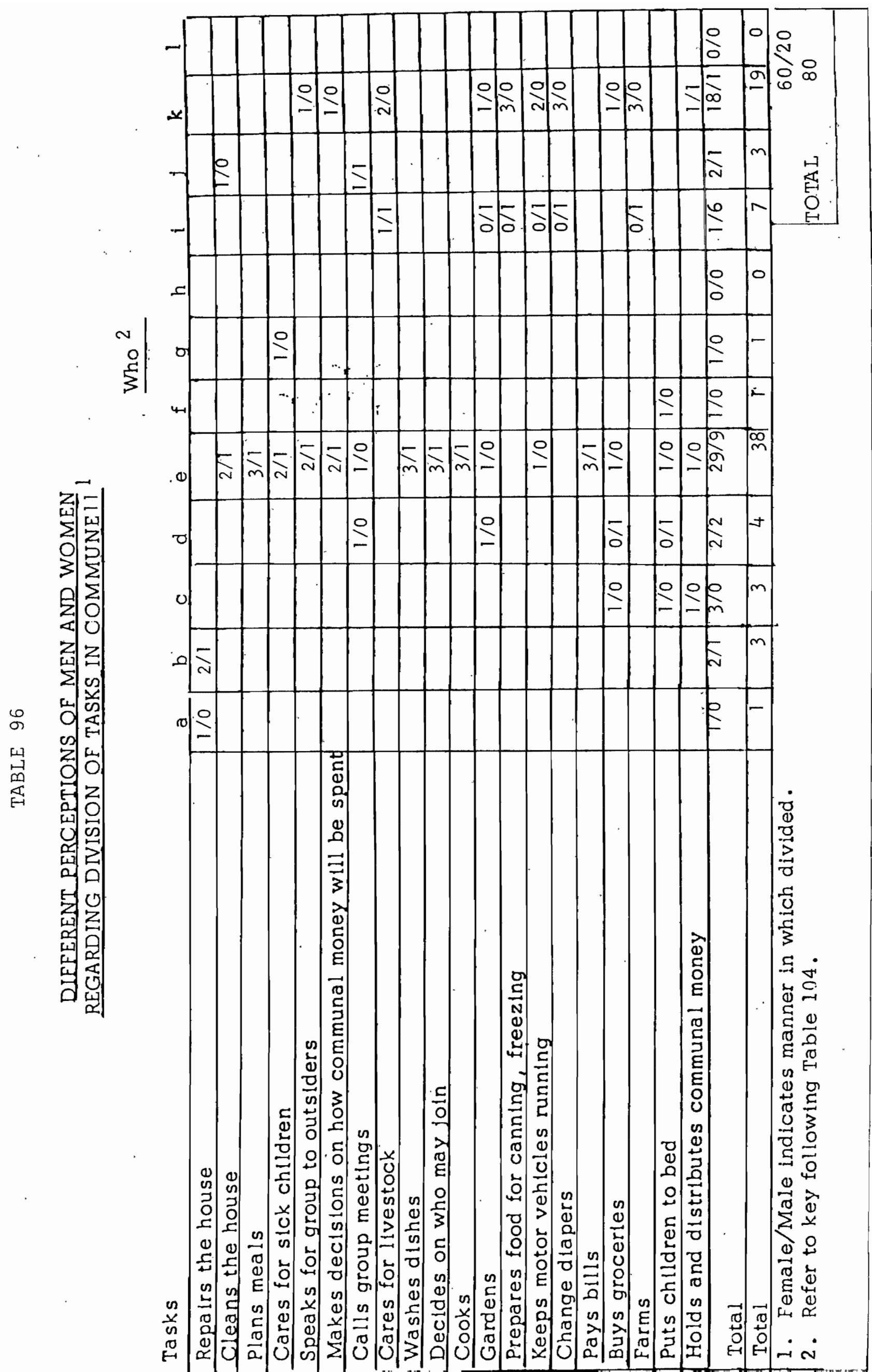




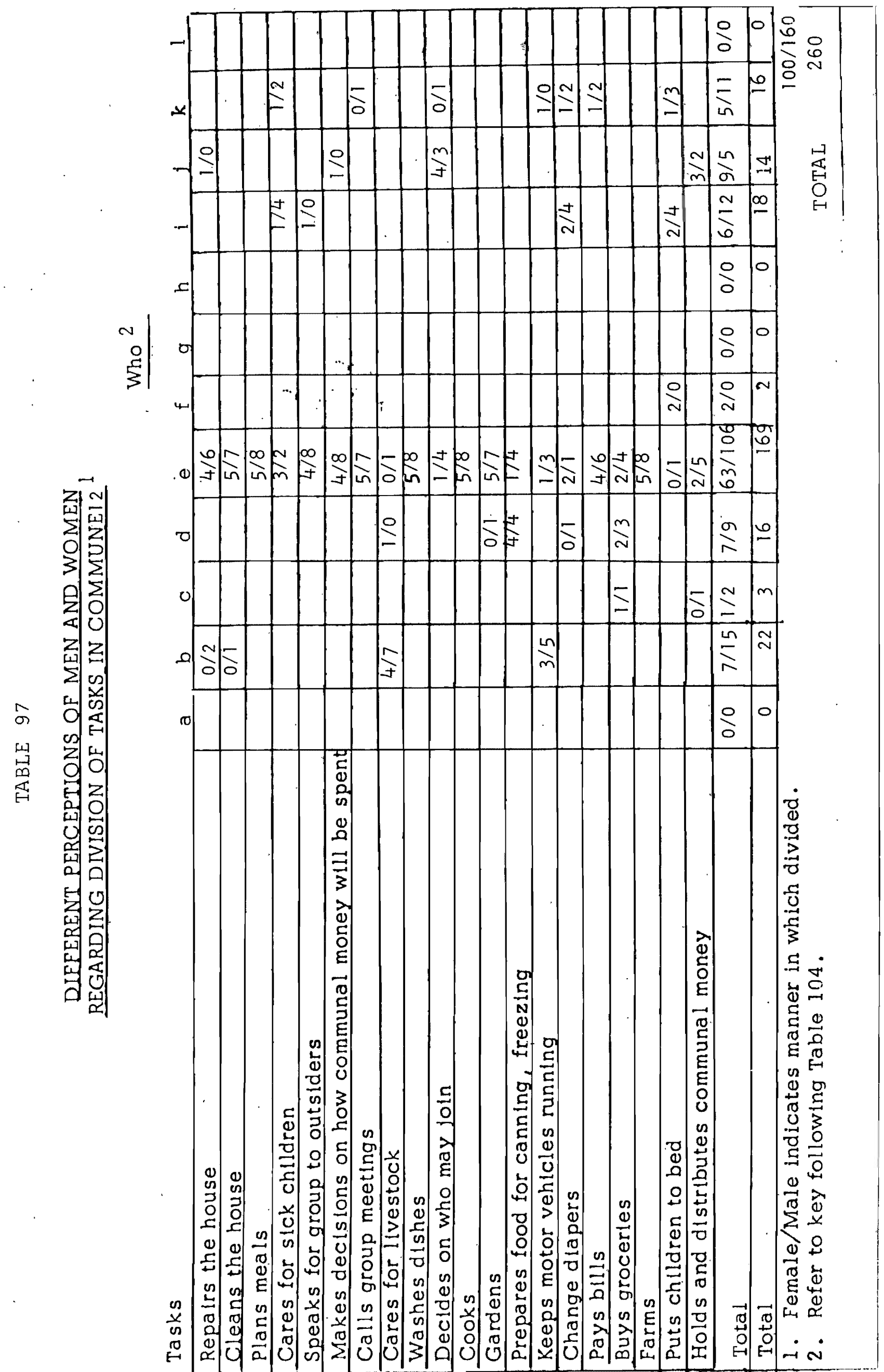




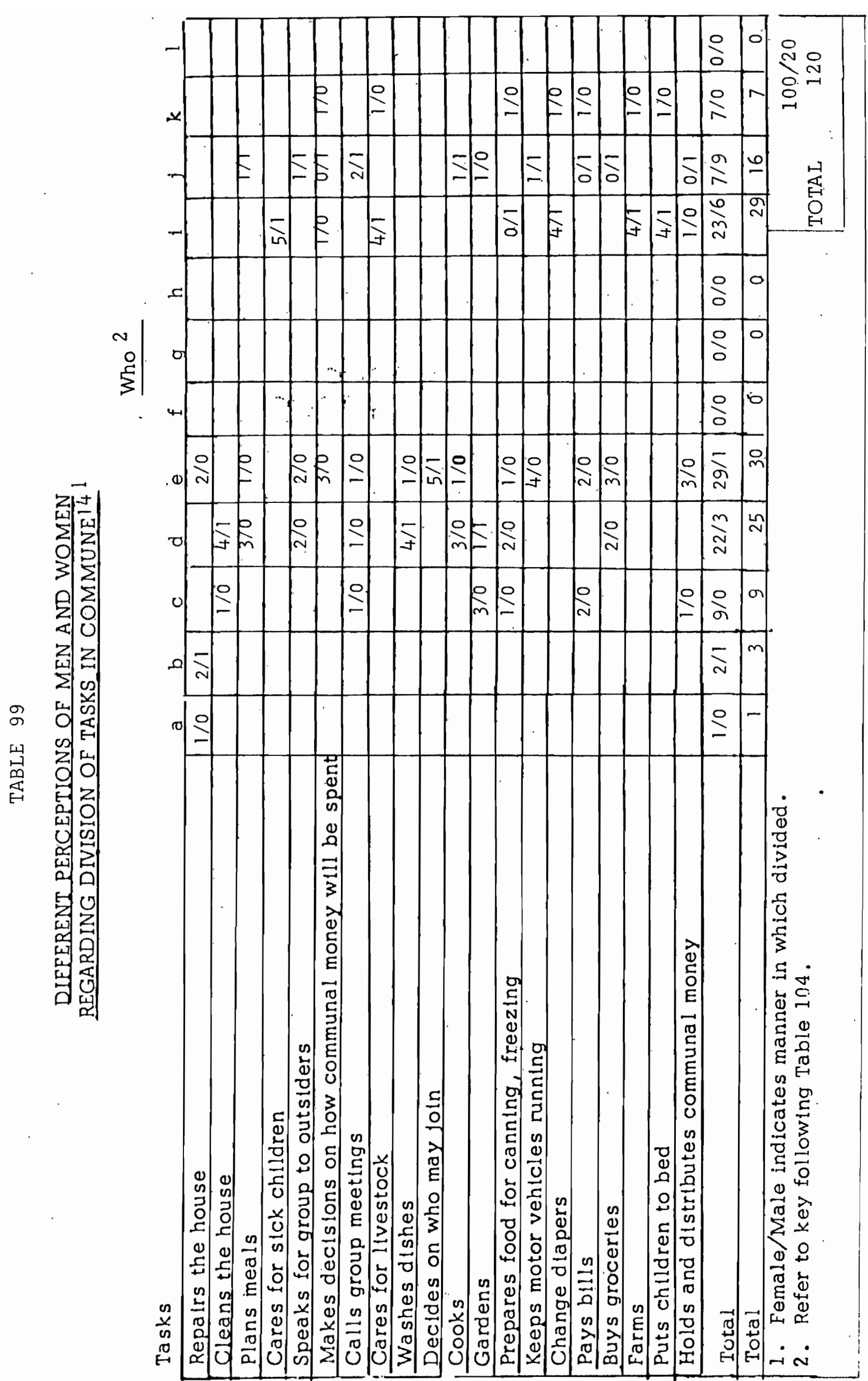




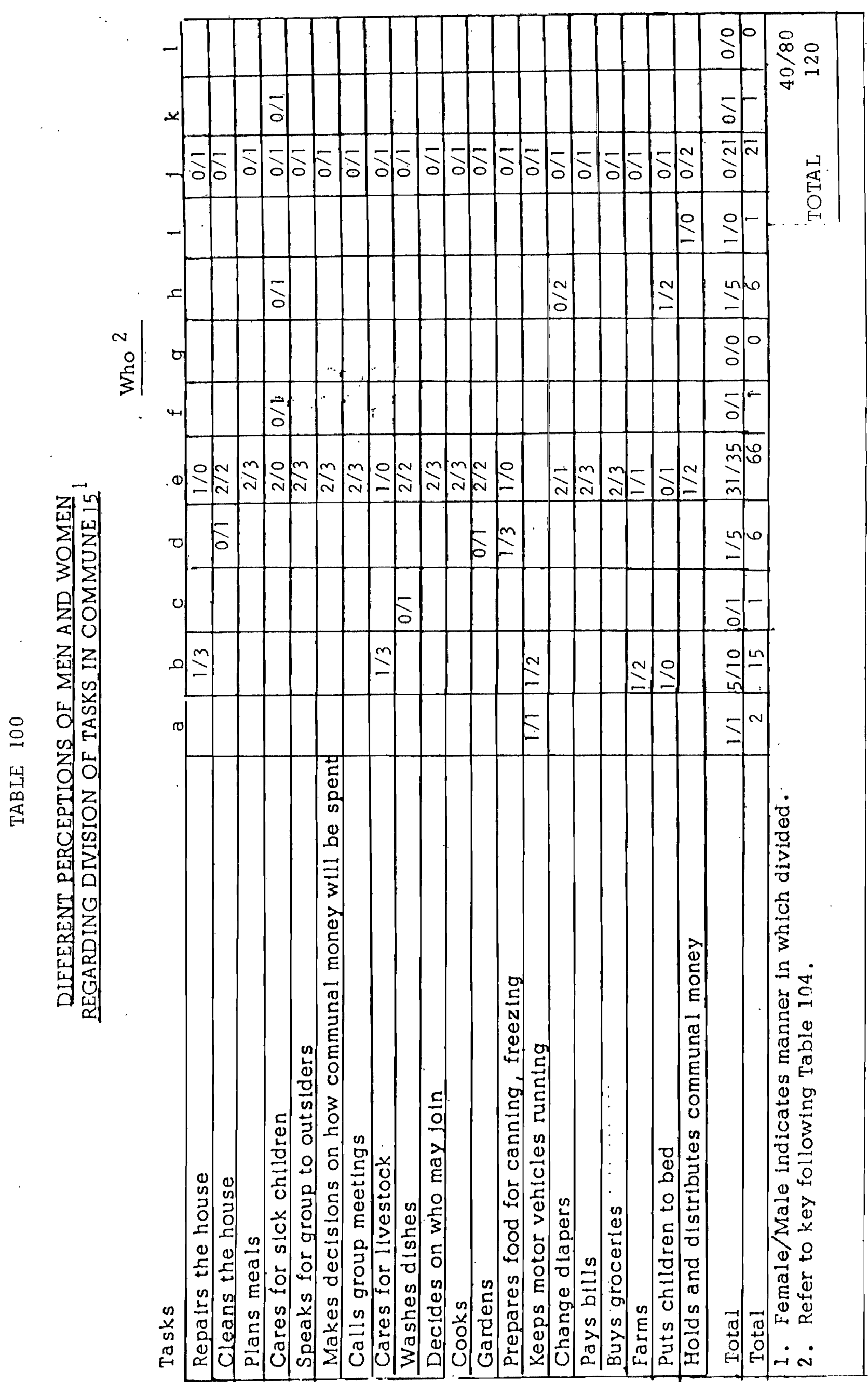




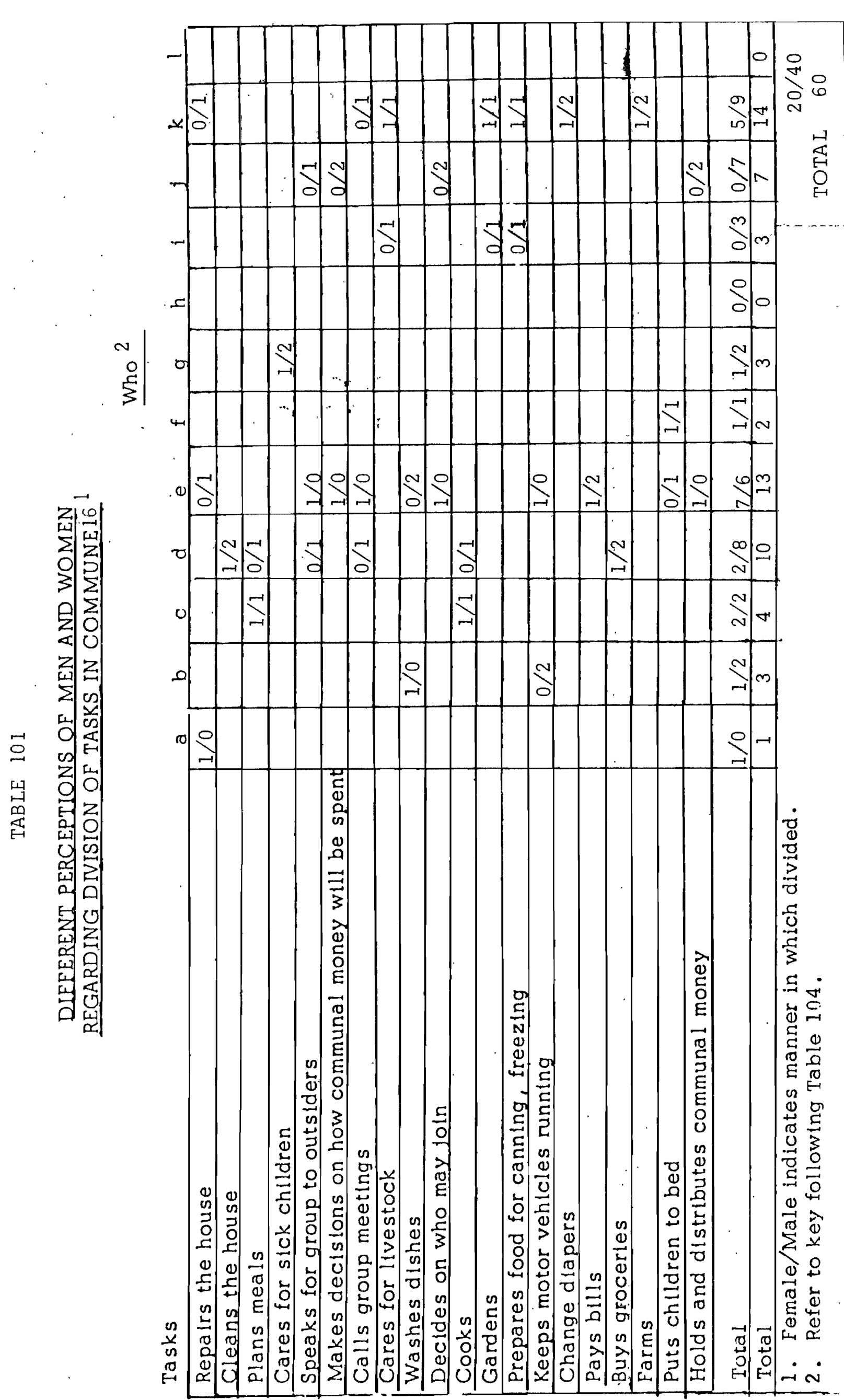




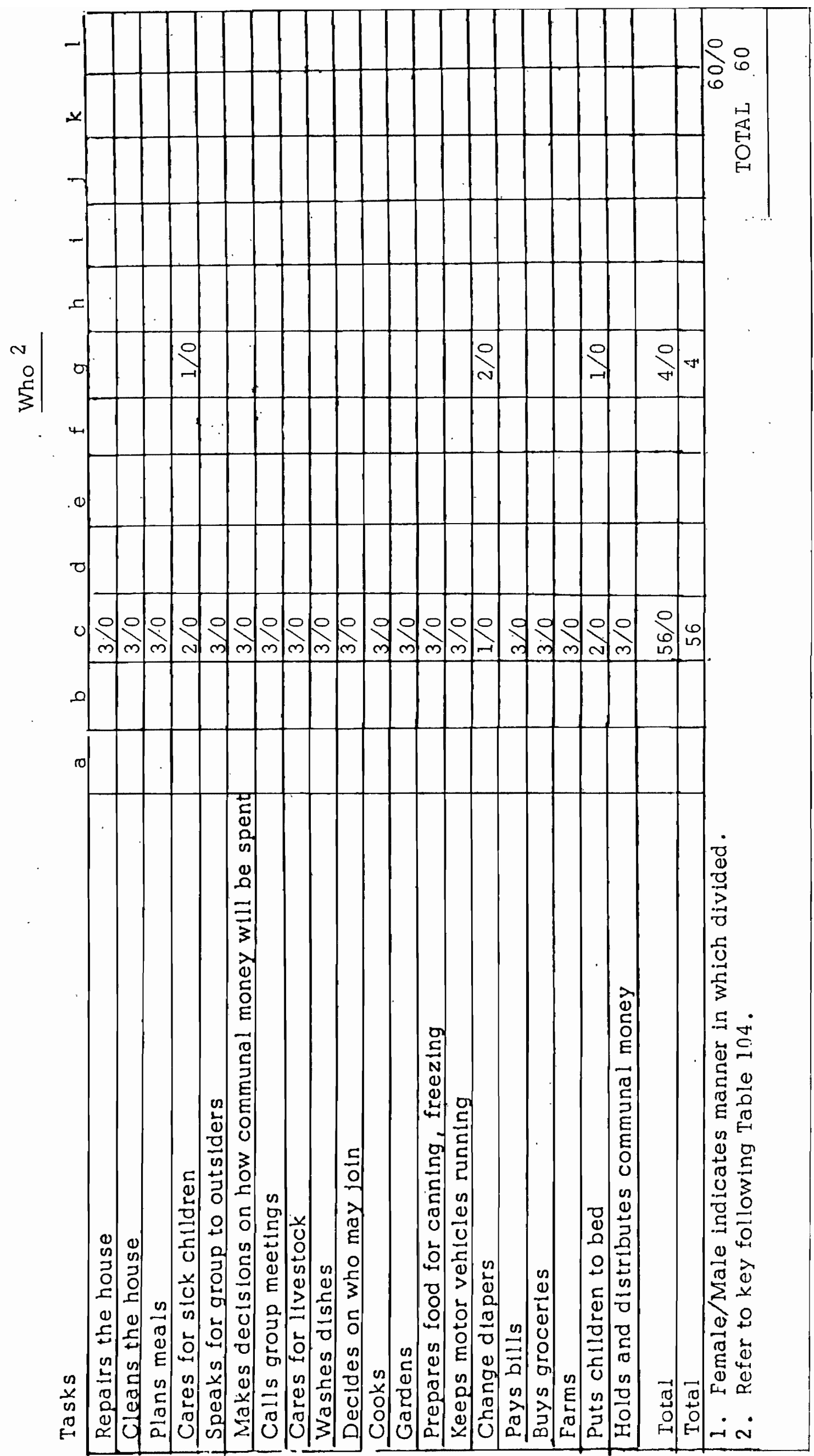




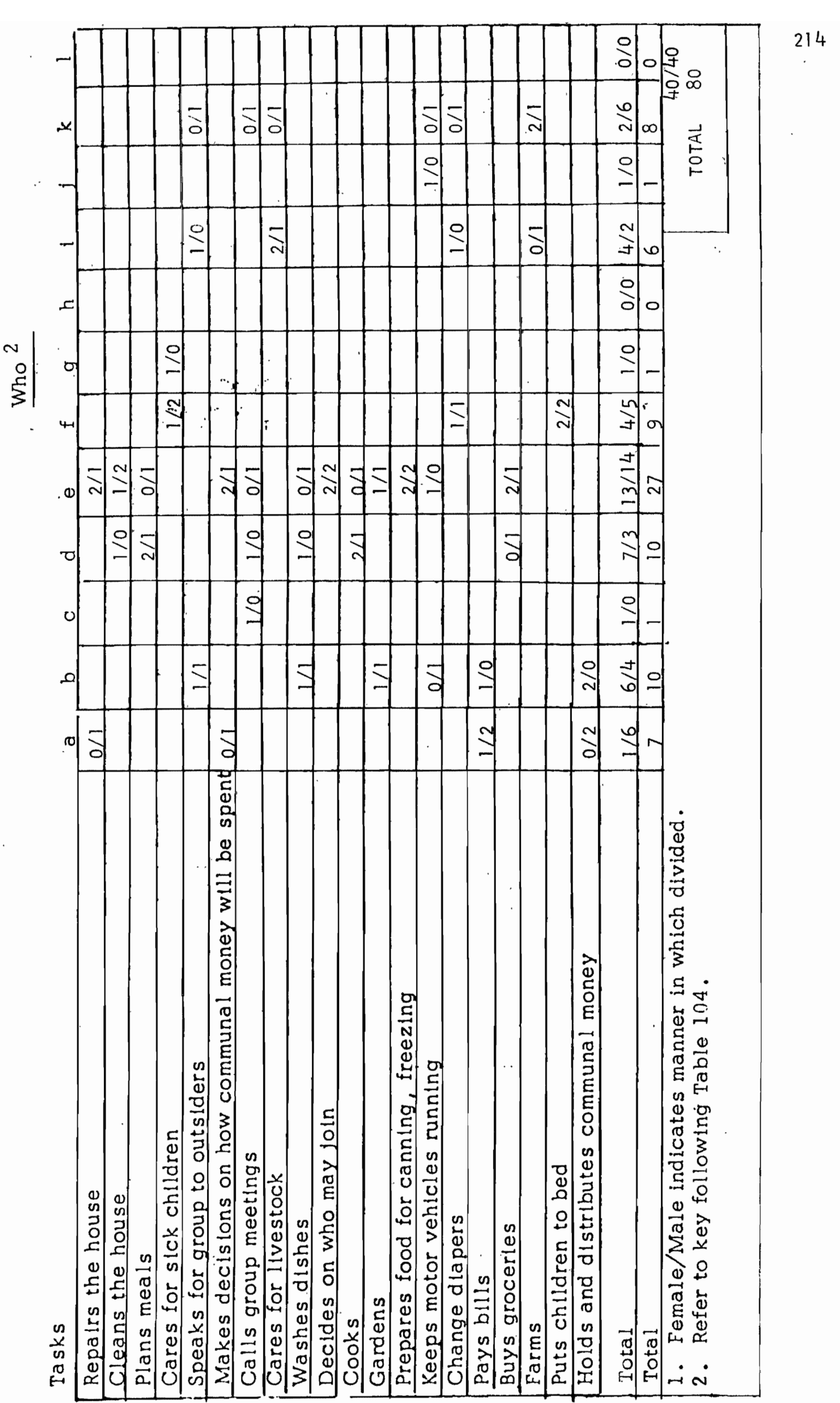


WHO

a. entirely done by men (a man)

b. mostly done by men (a man)

c. entirely done by women (a woman)

d. mostly done by women (a woman)

e. done by men and women equally

f. done by both parents equally

g. done mostly by mothers

h. done mostly by fathers

i. not applicable

j. other ( specify)

k. no response

1. uncodable response 


\section{PERCEPTIONS BY WOMEN AND MEN OF WHETHER OR NOT SEX ROLES WERE DISCUSSED IN THE FORMATIVE PERIOD BY PERCENTAGES OF THOSE WHO RESPONDED}

\begin{tabular}{|c|c|c|}
\hline Whether or not & Women & Men \\
\hline Yes & $76 \%(25)$ & $73 \%(19)$ \\
\hline No & $24 \%(8)$ & $27 \%(7)$ \\
\hline Fotal & & \\
\hline
\end{tabular}




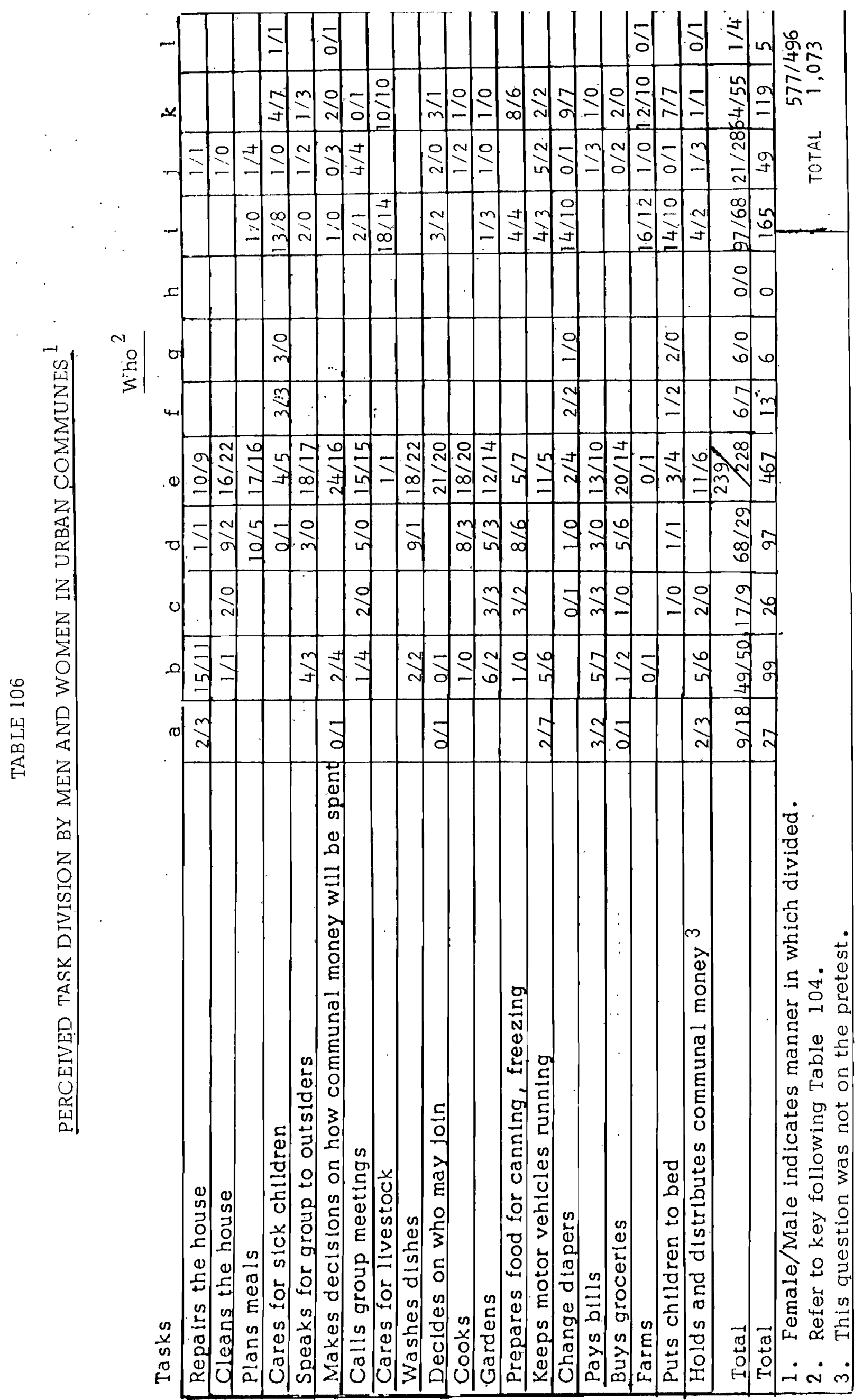


TABLE 108

IN UERCEIVED TASK DIVISION BY MEN AND WOMEN

\begin{tabular}{|c|c|c|}
\hline Who & Urban & Rural \\
\hline Entirely done by men (a man) & $2 \%(9) / 4 \%(18)$ & $1 \%(2) / 0 \%(2)$ \\
\hline Mostly done by men (a man) & $8 \%(49) / 10 \%(50)$ & $7 \%(22) / 8 \%(33)$ \\
\hline Entirely done by women (a woman) & $3 \%(17) / 2 \%(9)$ & $2 \%(7) / 1 \%(5)$ \\
\hline Mostly done by women (a woman) & $12 \%(68) / 6 \%(29)$ & $10 \%(29) / 10 \%(40)$ \\
\hline Done by men and women equally & $41 \%(239) / 46 \%(228)$ & $54 \%(159) / 52 \%(218)$ \\
\hline Done by both_parents equally & $1 \%(6) / 1 \%(7)$ & $4 \%(12) / 3 \%(11)$ \\
\hline Done mostly by mothers & $1 \%(6) / 0 \%(0)$ & $1 \%(4) / 0 \%(2)$ \\
\hline Done by mostly by fathers & $0 \%(0) / 0 \%(0)$ & $0 \%(1) / 1 \%(5)$ \\
\hline Not applicable & $17 \%(97) / 14 \%(68)$ & $7 \%(22) / 6 \%(25)$ \\
\hline Other (specify) & $4 \%(21) / 6 \%(28)$ & $8 \%(24) / 8 \%(35)$ \\
\hline No response & $11 \%(64) / 11 \%(55)$ & $4 \%(13) / 10 \%(42)$ \\
\hline Uncodable response & $0 \%(1) / 1 \%(4)$ & $0 \%(0) / 0 \%(0)$ \\
\hline Total & $100 \%(577) / 101 \%(496)^{2}$ & $99 \%(295) / 99 \%(418)^{2}$ \\
\hline \multicolumn{3}{|c|}{$\begin{array}{l}\text { 1. Female/Male indicates manner in which divided. } \\
\text { 2. Percentages are rounded to nearest full number. Thus they do } \\
\text { not always add up to exactly } 100 \% \text {. }\end{array}$} \\
\hline
\end{tabular}


DIRECTION OF NEW ACTIVITIES UNDERTAKEN BY MEN AND WOMEN IN URBAN AND RURAL COMMUNES

\begin{tabular}{|c|c|c|c|}
\hline Direction 1 & Urban & Rural & Total \\
\hline+ & $11 / 14$ & $14 / 9$ & $25 / 23=48$ \\
\hline - & $5 / 3$ & $7 / 8$ & $12 / 11=23$ \\
\hline 0 & $12 / 12$ & $3 / 6$ & $15 / 18=33$ \\
\hline \pm & $4 / 2$ & $6 / 4$ & $10 / 6=16$ \\
\hline $\begin{array}{l}+ \\
0\end{array}$ & $1 / 3$ & $1 / 0$ & $2 / 3=5$ \\
\hline$\overline{0}$ & $0 / 1$ & $1 / 1$ & $1 / 2=3$ \\
\hline No response & $6 / 1$ & $2 / 4$ & $8 / 5=13$ \\
\hline Uncodable & $0 / 1$ & $1 / 0$ & $1 / 1=$ \\
\hline Total & $\begin{array}{l}39 / 37 \\
76\end{array}$ & $\begin{array}{c}35 / 32 \\
67\end{array}$ & $\begin{array}{l}74 / 69=1432 \\
143\end{array}$ \\
\hline \multicolumn{4}{|c|}{$\begin{array}{l}\text { 1. Key for direction } \\
+ \text { activities cross traditional sex lines. } \\
0 \text { activities are neutral. } \\
- \text { activities follow traditional sex lines. } \\
\pm \text { respondents listed combinations. } \\
+ \text { " } \\
\text { o " " } \\
\text { 2. Many respondents listed more than one answer. }\end{array}$} \\
\hline
\end{tabular}


TABLE 110

LEVEL OF SATISFACTION (WITH DECISIONS REGARDING SEX ROLES ) OF MEN AND WOMEN IN URBAN AND RURAL COMMUNES ${ }^{l}$

\begin{tabular}{|l|c|c|c|} 
Level of satisfaction & Urban & Rural & Total \\
\hline Very dissatisfied (1) & $1 / 0$ & $0 / 0$ & $1 / 0=1$ \\
\hline$(2)$ & $4 / 1$ & $0 / 0$ & $4 / 1=5$ \\
\hline$(3)$ & $1 / 2$ & $1 / 3$ & $2 / 5=7$ \\
\hline$(4)$ & $3 / 10$ & $8 / 3$ & $11 / 13=24$ \\
\hline Very satisfied (5) & $13 / 9$ & $3 / 5$ & $16 / 14=30$ \\
\hline No response & $7 / 5$ & $5 / 10$ & $12 / 15=27$ \\
\hline Total & $\ddots$ & & \\
\hline Female/Male indicates manner in which divided. & \\
\hline
\end{tabular}


LEVEL OF SATISFACTION

(WITH DEVELOP MENT OF SEX ROLES WHERE NO DECISIONS WERE MADE) OF MEN AND WOMEN IN URBAN AND RURAL COMMUNES

\begin{tabular}{|c|c|c|c|}
\hline Level of satisfaction & Urban & Rural & Total \\
\hline Very dissatisfied (1) & $0 / 0$ & $0 / 0$ & $0 / 0=0$ \\
\hline$(2)$ & $4 / 0$ & $0 / 0$ & $4 / 0=4$ \\
\hline$(3)$ & $3 / 3$ & $2 / 3$ & $5 / 6=11$ \\
\hline (4) & $4 / 3$ & $3 / 3$ & $7 \angle 6=13$ \\
\hline Very satisfied (5) & $3 / 3$ & $1 / 3$ & $4 / 6=10$ \\
\hline No response & $15 / 18$ & $11 / 12$ & $26 / 30=56$ \\
\hline Total & $\begin{array}{c}29 / 27 \\
56\end{array}$ & $\begin{array}{c}17 / 21 \\
38\end{array}$ & $94 \mathrm{~N}$ \\
\hline 1. Female/Male indice & in ur & & \\
\hline
\end{tabular}




\section{APPENDIX $G$ \\ DESCRIPTION OF GROUPS IN SAMPLE}

Group one

Group number one is a rural household located in an area in which farming predominates. The original group formed in a metropolitan area, living in houses together and preparing for a move to a farm. Most of the early members had been active in nonviolent opposition to the war in Southeast Asia and other similar causes. They felt frustration at the lack of results from these efforts and decided they might better find a life more satisfying to themselves, at the same time providing a model for others of like persuasion. They did not approach this latter goal in the manner of a crusade, rather leaving the impact to be made gradually as people came into contact with them and came to appreciate the value of their life style. The community occupies a large piece of land which includes some open farming space and a lot of wooded portions, with a large stream flowing through. A good deal of effort has gone into clearing, planting, and building . The present buildings include a common house in the shape of a geodesic dome, a nearly completed barn, chicken and rabbit pens, and approximately sixteen small houses built by individuals or couples for personal use. These latter are scattered in such a way as to provide considerable privacy if this is desired. A small dome which was originally built to house children during the first phase, while adults slept in tents, is now used as a family dwelling. There is a plan by one of the women to build a scientifically designed structure 
for the raising of rabbits (of which there are already a large number). There is a large garden and pasture and it is planned that grains will eventually be grown.

The general condition of the buildings and property is about what might be expected where a large group is living much of its time out of doors. An initial impression of untidiness and dirt gives way to observation that open shelves, boxes, etc. have been designed to organize belongings in a way that is accessible and obvious to those who need them. There is a good deal of furniture, arranged around the circular room in a way which maximizes a sense of community and inclusion (whether intentional or not). The individual houses seem fairly tidy, and each that we saw was distinctive enough to reflectsomething of the individuality of the persons using it. Although simplicity of life is stressed, there is a very well-equipped workshop and some modern household equipment (eg. a freezer). It was mentioned that the members felt it wasteful of human energy to go overboard on a complete return to primitive work habits.

Since we had had a brief contact with the group at the time of an earlier open house, we did not feel complete strangers when we arrived with the questionnaires. Those whom we met seemed open and friendly to outsiders on both occasions. There are several neighbors who have become close friends and supporters of the group after an initial period of suspicion. The tone of local response was seen to change drastically as reflected in a scrapbook containing articles from the local paper, spread over the period of their first three years. In their relations with each other they appeared open and 
affectionate. They were straightforward in remarking on differences that have developed since they have been together. One of the founders, who is no longer resident, had commented during our earlier visit on his disappointment in their gradual move away from complete sharing of all resources. Another person mentioned that restlessness had set in after the very hard task of getting shelter built was over. It was difficult for some to find additional meaningful activity and some left the group at that point. Considerable change has occured in the outward signs of community as individuals have gotten into places where they feel comfortable. Meetings have decreased and people do not feel the need to cling closely to each other. For some this represents a diminution of community, for others a level of trust reached that no longer requires such outward support.

At time of formation the group was incorporated as a church based on nonviolence and humanistic and ecological principles. This was to allow nonprofit status for land purchase and also to permit the formation of a school. The school was not successful even though there were a number of community children and parents involved. It was seen as of too low a priority, especially for those without children. Children have been a source of tension in the group. Differences about rearing practices and responsibility have led some of the single or childless adults to declare their plan not to have children themselves. Only the child who has been in the group since infancy is seen to approach the ideal the founders had in mind in terms of development. 
Group two

This urban group consists of three legally married couples and four children. They became friends while working on service projects and decided to expand this friendship through jointly buying a house and living together. Initially they planned to provide a community service by housing ex-convicts, or others in need, on a short-term basis. After brief experimentation with this, during which they were robbed of various possessions, this focus has been dropped in practice. Nevertheless, the idea still appeals to some members and dissatisfaction was expressed by one that they weren't doing this and had not really made a decision as to whether they would do so in the future.

This group sees itself as very middle class and lives in a large, neatly kept house that is tastefully but not elaborately furnished. Banners and posters reflect the religious orientation of the group which might be termed Catholic social actitivist.

These people were friendly and outgoing to us and seemed comfortable, open and affectionate with each other. Most hold professional or business jobs in the community and are invol ved in political and social activism. Two of the men were working intensively for political candidates at the time of our visit. They seemed very aware and concerned with quality of life issues and also with the quality of education their children were or were not receiving. Observations during our visit there indicate that the children are actively encouraged and allowed to learn to do things without adult hovering. They were put to bed by one of the men after gleefully singing to his guitar music. 
(iroup three

The members of this group live in a large house in an urban area. Members are politically active and see their household as a tool to allow them to work more effectively in areas of social change than they could do if isolated from each other. They also see it as a model for community . Members work for various groups related to social and political concerns, at recycling and at various unskilled jobs to bring in money for their living and for other projects. Many of the members are related in some way or other to the local Society of Friends and reflect the philosophy and style of this group.

The house in which they live is owned by a land trust composed of more persons than those currently resident. It is seen as a permanent home even though individuals may come and go. The downstairs is simply furnished and fairly neat. The house is used for a lot of group and community meetings . There is a garden which gets attention on and off, but which at the time of our visit did not seem a high priority for any of the present members.

The group is friendly to outsiders but seems careful to avoid any appearance of recruiting. This latter is in spite of the fact that all are involved in worthwhile activities that are always short of help and resources. The members seem open and relaxed with each other, aware of what each is involved in and appreciative of it. Later contacts indicate occasional frustration experienced by members at not being as ideally accepting of each other as they want to be. They seem very aware of their need for growth in this area. 
Group four

This urban group of four single persons and one married couple met while they were all students at a small midwest college. They are basically a friendship group who banded together to rent a large house on a lake in a midwestern city. Financial economy and friendship are dominant in their arrangements. No particular political or religious philosophy seems to be present as a focus for the group.

At the time of the visit only the women were at home as the men were working or attending evening classes. Follow-up efforts to get responses from the men have been unsuccessful.

The house has a screened porch facing the lake, is clean, neat and tastefully furnished with articles donated by residents and parents.

The response of the women was open, friendly and enthusiastic. Among themselves they seemed to express warm, close relationships. Particular mention was made of the fact that physical sexual relationships, except for the married couple, are only with persons outside the house. Generally, this group seemed middle class in approach, with economy and friendship expansion seen as the major advantages to group living .

Group five

This urban group is attempting to combine elements of gestalt therapy, primal therapy, selected drug use, sexual experimentation, and ecology to achieve an integration and power for personal and social use. The leader of the group sees himself, and is seen by the members, as a definite leader, 
somewhat of the charismatic type. He is seen as the one through whom. the above elements are channelled to produce a creative and constructive group life. They are into yoga, meditation and other similar emphases but are also concerned with political, educational and social issues. They operate a bookstore through which these ideas and efforts are channelled into the community.

At the time of the interview they were living on the third floor of an old house. The house had a minimum of furnishings, mainly mattresses and cushions. The considerable clutter was apparently well-organized, as the leader was able to reach into pile after pile of papers to draw out something to illustrate a point in discussion. From the interview and subsequent contacts it would appear that the distribution of literature is seen as a major part of their service.

The group members appear to welcome visitors and inquirers, although they wish their times of meditation to be respected. They made several open invitations to other students whom we might want to sent to meet them.

Among themselves they seem affectionate and respectful of differences and individual "space". The leader, however, is definitely shown deference and definitely acts as a "family head".

Group six

This urban group of single persons in their twenties have all participated in Transactional Analysis groups and are enthusistic about the help they have received. They see themselves as somewhat of a half-way house but are self organized and administered. Longevity for the group does not 
seem to be sought or desired; this arrangement is seen by them as a necessary, desirable phase between treatment and going on to something else.

Persons with both heterosexual and homosexual orientation are part of the group. However, sexual relationships are not allowed within the membership. They stressed that they feel avoidance of sexual liasons among members contributes to their stable, good relationships.

They live in a single house where they feel individual members' rooms are too small. Common areas of the house are clean and tidy. Mention was made that this standard is expected, but that each individual has the freedom to maintain his/her room as personally desired. The house is located in what appears to be a middle class residential neighborhood.

They were very friendly to us after an initial reticence and told us of other groups we might want to visit. One male member became particularly involved in describing his personal background as a rejected, adopted child and his experience around sex role expectations in the shipyards where he works.

One of the cardinal principles in their relationships with each other is openness. This was mentioned repeatedly by various members. Group seven

This large urban group. sees themselves as a family and a church. They claim all have had visions which brought them together with the purpose of following the example of love in the New Testament and thus serving as a model for all that this love can be lived in the modern age. The founder is 
a male who represents Christ. Through consent of all members (pursuant to joining), he has the final word in all church matters. Church matters seem to be pervasive and cover all life activities. Elders are in authority in each living group. They are "appointed by the church" and are all men. There is some rotation of elders.

This group seems entirely communal in that upon joining, all is given to the church to be distributed by the elders as needed. The group lives in nine separate houses clustered in one neighborhood. They openly state they are attempting to buy up property in this neighborhood, to take it over and to live as an embodiment of love. Their creed is contained in a beautifully illustrated book which contains selected Bible verses and their church dogma relating to authority, their family, marriage, holy names, the bread of life and eternal life.

Members don't marry in the usual sense but are bonded together, apparently only for the purpose of procreation. This seems to be based on the idea that too close a couple relationship detracts from the solidarity of the group as a whole. Women are to relate to men as godly examples. The women seem to be gladly submissive, not seeing themselves as inferior by this but simple living out the creed that the man is the head of the woman as Christ is the head of the church. In spite of this there seems to be no strictly sex-related division of tasks.

Obedience of children is stressed in their book, with the idea that adults will only give good counsel to children and are raising them to be good, loving people. When asked, an elder stated that once a child reaches 
a certain age, that child can decide for himself/herself whether or not to stay. 'The age was left vague.

Holy names embodying a Christian virtue are given to members by the leader when their virtue becomes apparent. Some of the names we heard included Frankness, Honesty, Respect, Imagination, Melody. All members share the same surname, which has a biblical origin.

This group was very friendly and hospitable to us, spending much time telling us of their philosophy. They were cool and skeptical toward the questionnaires so we did not push this. They commented on the impossibility of capturing what they are in words, and the need for a person to be among them to understand. Evasiveness about dates, numbers, and finances was noted as was the unclearness of their relationship with civil authorities. They said they were "in tight" with the police, but an outside observer related to us their hassles over utility bills. The group apparently feels there are some things they should not have to pay for.

We visitied only the "guest house" which is next door to their storefront. This storefront seems to be a communications and public relations center as well as a distribution point for their own food and supplies. It does not appear to function as a commercial enterprise. The guest house is very simply and beautifully furnished. Neatness and color predominate. Colorful paint and flowers outside with a special bench made for the bus stop indicated their desire to be a pleasant site in the neighborhood.

The group seems very caring and loving of one a nother, joyfully ombracing each other and singing together over dishes. Peacefulness and 
gracefulness seem emphasized.

Group eight

This urban household serves as a clearinghouse for various types of alternative living groups and alternative social projects. A few members work in the community, supporting the rest who give their time to the above tasks. The plan of this group is to buy a large farm as well as maintaining their urban center. They expect this to make it possible for persons to move back and forth between the two kinds of life and to thereby keep their energy level at its best. The house, located in a middle class residential neighborhood, is large. It appeared fairly crowded, with a maximum number of residents plus office space for the preparation and organization of mailings. Books and papers were in stacks and the two in the office expressed some discouragement at the way paper work piled up. The overall impression was one of some clutter, but not of dirt or of unnecessary stuff lying around. There were plants and posters in profusion, also some cats and a large dog.

Members seemed friendly to outsiders but expressed resentment of the demands and impositions of people who feel they can just drop in without warning. All feel they are busy at important things and do not need that kind of thoughtlessness. As far as answering our questions, the person who appears to be something of a leader in the group commented that perhaps some school counselor would read the results of our work and realize the setting in which particular kids had grown up was not so bad after all. On this basis he felt it worth his time to talk to us and fill out the questionnaire. There was a 
strong objection expressed to the use of the term "commune", in that the emotional overtones which this word has for some people might nullify the value of our findings for such a reader.

Group members seemed fairly open with each other. Where tensions were either seen or mentioned they expressed their awareness of the need for growth in this area. A house book of notes, poems, pictures, etc. reflected a continuing struggle for them to understand and accept each other and also to help each other see weaknesses and work on these. One lengthy discussion growing out of a question disclosed a very long standing misunderstanding between two members as to how one of them had felt at the time of formation.

Group nine

This urban household is made up of people who have served as volunteers in church related service projects. They live in a large house located in an old section of a large city. The neighborhood is an attractive one of old houses, with some evidence of racial mixture among residents. The members of the group share a common religious motivation for their individual and group life. Some work at community jobs, one gives full time to community organization work and all serve in church and community service projects.

The house is very neat and clean, comfortably furnished without being elaborate. A guest room and library is always available for a person who might wish to stay. 
The group apparently feels no sense of separation from persons who might be termed "outsiders", recognizing themselves as basically middle class in orientation even though they have chosen this living arrangement. The nuclear family is revered and supported. At present there is one married couple with a child. Anyone who marries is required to live away from the house for a least a year, but may return after that if they desire.

Members seem relaxed and open with each other. Several were friends before joining the group. There was good natured jokina and deference to cach other in discussion. The only child is seen to present no problem at the present time. All consider themselves involved with him at various points, although he is headquartered with his parents. Group ten

This urban household is a very loosely organized group of friends. One member remarked that the basis of the group was very shallow and that he felt he would not want to remain if it continues on this level. There seems to be no major unifying factor for the group other than the idea that sharing is a good thing in itself.

The group occupies a large house in an old, well-kept urban neighborhood. The house and yard are attractively maintained; considerable work in cleaning and painting having recently been done. One room is filled with well-tended plants. Four friendly dogs run loose but do not seem to be considered nuisances. Members are friendly with neighbors, but only one is 
agressively so.

Among themselves the group members seem relaxed, although

this group did not sit down with us to answer the questions so impressions are a bit more nebulous than is true for the others. They did make jokes about the vigorous discussion that grew out of the questionnaires. Group eleven

This urban group began on a friendship basis with members varying in their reasons for joining. Economics is the only common reason but experiment in group living and emotional support were also mentioned. The group is joint ly buying a very large house which provides a great deal of privacy for each resident This was openly recognized as different from most urban groups and as a possible reason for their survival as a group. They perform a service function by offering their home to student trainees from a nearby grade school which their children attend. The children (ages 8 , 11 , and 13 ) seem quite independent and are encouraged to be so. The school they attend also encourages this.

They were friendly to us and somewhat interested in the topic of our study. Relationships between the members seem caring and fairly open. Group twelve

This rural group is formed around the basic values of nonviolence, ecological use of the land and mutual support, all of which are central to their life and work. They do not consider themselves a drop-out community. They operate a bookstore in a nearby town and work at various occupations 
ind in service to the community. They fecl the farm represents a model for an important style of life. The group has some fairly structured characteristics, particularly in their regular cycle of meetings and specific responsibilities resting with certain groups. The meetings are related to the following special emphases: business, worship, personal encounter and spiritual. In addition subgroups are responsible for farm matters and finance. Leadership for each of these meetings and subgroups is assigned by consensus, usually on the basis of volunteering, and is stable for one year. This is the first group visited with a wide age range. This appeared to be an accepted and comfortable arrangement for members.

The group seems friendly to outsiders, were very cordial and well prepared for us. There were several other guests present for the day. Reception of guests represents some sacrifice of group fellowship since they have only two Sundays a month when they are all home and free of meeting commitments .

Among themselves members seem very open and affectionate. Only one incident of stress was noted in the effort of one member to get away for an afternion appointment. He did not receive much support in his mood of haste. Some family units are apparently intact in the sense of being permanent nuclear families within the community. However, multiple sexual alliances are reported by some members of the group.

Group thirteen

This rural group lives on a fairly large farm in a mountainous area where logging is a major industry. The land was originally purchased to be 
developed into a retreat. The original owners who were involved in social service and action failed to use it and allowed this group to live on the property. They are now in the process of buying the land themselves.

No particular philosophy or reason for formation holds this group together. Some members seemed self-conscious about this and expressed dissatisfaction with lack of group solidarity.

Lack of jobs in this rural setting, especially jobs for women, is a source of some difficulty for this group. They would like to attract more women, as two women described as feminists recently left for lack of opportunity in the area.

A central house with kitchen, dining area and living room with a concentration of books, records and other shared items is the major meeting place. Small houses for couples and singles dot the landscape, each in an attractive, private setting. Design of these small houses is individual, varied and extremely attractive. There are also a well built chicken house and other small buildings for goats and other garden supplies.

Some of the group were very interested in the topic of our research and spent much time discussing their ideas about it and asking for our findings and experiences in other places. They took advantage of our visit to think through questions related to their group solidarity. Group members seemed fairly relaxed with each other but did not seem to demonstrate the closeness observed in some groups. 
Group fourteen

This small urban group is made up of politically active single persons. They live in a large house in a middle class residential neighborhood. Most take jobs that will allow them a maximum amount of time to give to political and social action projects.

The scheduling of a time when most could be present for the questionnaire was difficult because of the varied responsibilities of different members. However, when the time was finally set, all current residents were present and gave a good part of an early evening to careful answering of the questions. They seemed responsive, friendly and generally interested in the topic of study. Among themselves they seemed open and affectionate.

At the time of the visit the group was planning to incorporate several other persons of like interest and then redivide into two or three houses. Group fifteen

This rural group consisted mostly of people who went to the same college and knew each other at various levels during that time. One couple was buying a farm and others heard about it and came to visit. The group formed gradually and now all are contributing to the buying of the land. All are college graduates and some have graduate training. Their present situation is seen as an alternative to the nine-to-five rat race, although all but one of them hold some outside employment in the neighboring community.

The communal area at this point is an old trailer house which serves as kitchen, dining and general socializing center. Couples and singles each 
have their own shelter for sleeping and privacy. These vary from a tee-pee, to two cottages which were on the original farm, to some ingenious structures built by the residents. A communal kitchen was in the process of building at the time of our visit. The original barn, remodeled by residents, is used for pigs, goats, a cow and a horse. Care seems to be taken with gardening and selective breeding of animals. Some feed grain has been grown for their own animals.

Members were very open with each other and although many differences emerged, they seemed to tolerate this well and use it creatively. According to one woman resident this group is considered to be permanent.

Their reaction to us was mixed, but not at all hostile. Some were genuinely interested, one man indirectly took issue with studying humans in such fashion, and some were cooperative but seemed minimally interested. Group sixteen

This group of two married couples and four children is in transition from living in a small northwest town to a rural setting fairly close by . They met as dissatisfied surburban couples who were at first part of a larger group of five couples wishing to expand their relationships and horizons. This larger group discussed rural communal living for some time until differences emerged and the present group solidified. According to the present group, the other couples had different motiviations such as group sex and "making a killing on the land". 
They characterize themselves alternatively as middle-class and ex-middle-class. The men are presently commuting to a metropolitan area four days a week for ten hour days at steady, professional jobs. They hope to be able to cut back to less time in the future. Construction at their 22 acre farm is being done by the women when the men are working and by all the other three days of the week.

We visited them at their duplex apartments in a small town so did not see the farm where they hope to be by Christmas 1974. They are building three modern buildings at the farm, one double A-frame bunk house for each family and a communal A-frame structure consisting of kitchen, dining, living and laundry facilities. Electricity and plumbing will be in all three buildings in contrast to most communal groups we visited where bunk houses were usually without such.

This group pools their incomes for basic living expenses. What is left over is used by the individual families. The two families are of the same size and have similar incomes. They see this as rea son for little difficulty with this arrangement. Expansion of the group seems to be desired if prospective joiners fit in with their values and life-style. This group also has a cooperative arrangement with their rural neighbors (other communes and nuclear families) for things such as shared gardening, shared tractor, etc.

They were extremely open to us and seem to have solid, lovina relätionships with each other. A lot of interest was shown in what other communal groups are doing and what we had learned in our visits. 
Group seventeen

This group is the only single sex group in the sample. A small group of women live together on a farm in a basically agricultural area. The farm has been purchased to be maintained in perpetuity as a property specifically for the use of women. A small house and a trailer currently serve as housing for the group, but other dwellings are in the process of construction. The residents are attempting to do all maintenance and farming tasks without depending on the help of men and feel they are relatively successful at this point.

All present expressed appreciation for the support they gain from their ties with women's groups centered in a nearby metropolitan area.

Not all residents were present at the time of our visit but those who were seemed open and outgoing toward us. They were generous in sharing not only the information requested but also some of the problems they face both within the group and from external pressures. Group eighteen

This urban household consists of five graduate students, three men and two women. They got together as friends and as people who wanted to live in a house with other people rather than in isolated apartments. This group has been together the shortest time of any in the sample, just a little over four months at the time of our visit. A group of sophisti cated people, they are highly conscious of sex role considerations and appear to be confronting each other fairly regularly regarding stereotyping of men and women. 
They rent a single house in a dense portion of a northwest metropolitan area. The house is fairly large and furnished with objects contributed by all members.

They were very open to our study and personally sharing of their views and feelings in a subsequent discussion. Relationships among the group seemed to be caring, warm and quite direct with a noticeable tendency to honestly face differences .

Group nineteen

A large old house in a northwest city is the home of this urban group. Two married couples, one with a child, and several single persons share their living here. All members are fairly young and in touch with social and political currents affecting sex roles. They were generally interested in sharing their ideas and feelings in this area, although all were not able to participate at the time of our visit. Although members share many common interests they also pursue individual concerns. What they give to each other is more in terms of individual support than of mutual help in any kind of external or internal common cause as may be identifiable in some groups.

The house in which they live was originally rented jointly by the two married couples and there has been some turnover in the other persons who have joined them. They do not see themselves as a long-term permanent group but have no plans for separation in the immediate future. Several are students and see their future residence as largely shaped by job opportunities. 
The house has the attractiveness of being very old and is kept neat and clean. It is well stocked with the books, records and personal belongings of the various members. The group was open and friendly to us. 


\section{APPENDIX H \\ FINAL LETTER TO SAMPLE GROUPS}

Greetings,

Now that we have finally completed the task of putting together and examining the very helpful material provided by all of you who participated in our study, we wish to thank you again.

We realize now, even more than at the time of our visit, how much we have learned and hope that this will be reflected in increased sensitivity personally and professionally. We are aware that we promised feedback earlier, but we simply did not anticipate how long it would take to complete the project.

We are including specific sections of our final write-up which we thought might be of most interest to you. Sections included are interpretation of findings, conclusions and an epilogue suggesting areas for further study. For those of you who may wish to refer to them; the questionnaires used are included. For those who would prefer not to wade through all of it, perhaps the conclusions and epilogue would give a general picture of our results. If anyone is curious about the design of the study or specific data, we would be happy to provide other sections or answer specific questions. Also, we would appreciate any feedback you might wish to give us. In addition, if in glancing over the epilogue, any particular question raised seems of importance to you perhaps other students might be interested in following up on this.

We would like to comment on one specific issue since it was raised in several groups. This is the use of the word commune and the resultant 
search for a more inclusive term. Groups we visited called themselves by many different names such as communes, extended families, living collectives, intentional communities, collective households or just people living together. We hope that the term we decided to use, "cooperative household " although a compromise, will be seen as appropriate. Again, we appreciate your receptiveness and willingness to help. We began with hesitancy to intrude and instead discovered interest and welcome from many of you. This was one of the best experiences in this study.

Sincerely,

Billie Huntwork

Emily Fultz 